Historic, Archive Document

Do not assume content reflects current
scientific knowledge, policies, or practices. 
<smiles>C1CCC1</smiles> 


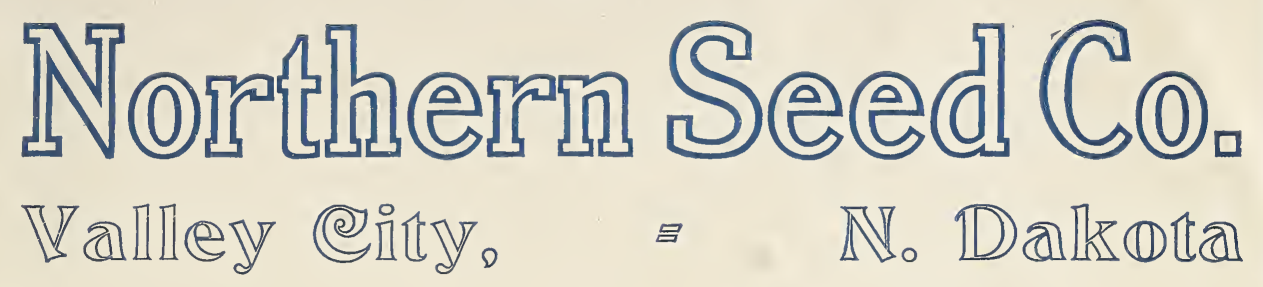

Catalog 1920

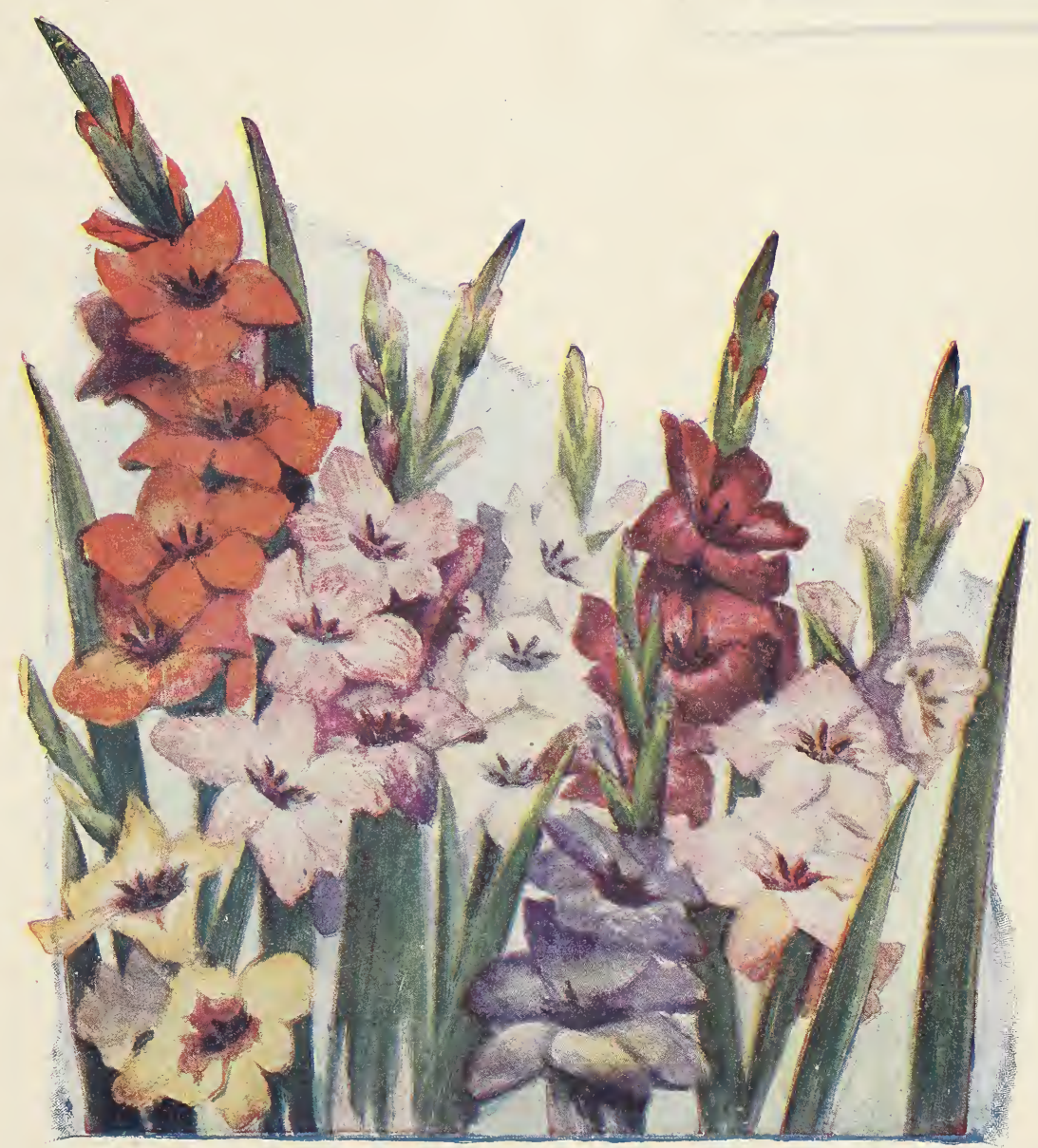

Our Extra Fancy Gladiolus 


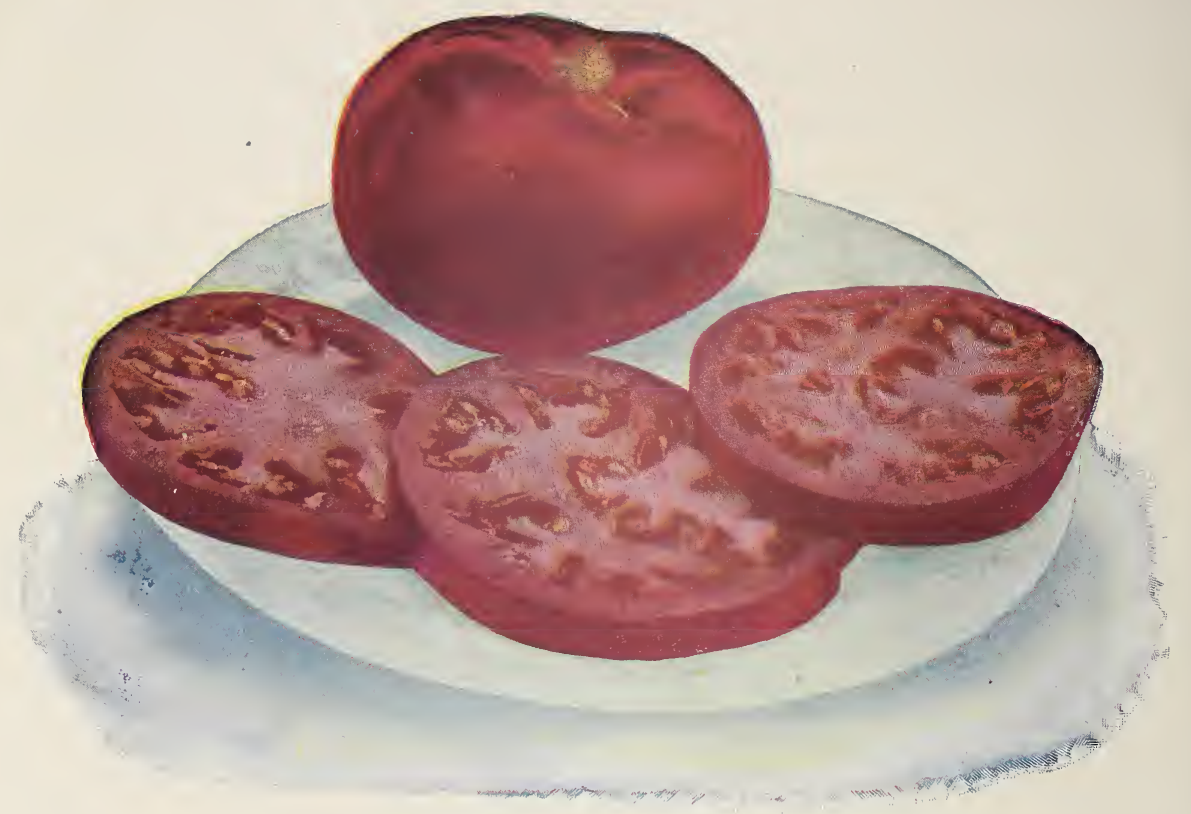

\section{Earliana Tomato}

Our Earliana Tomato is extremely early, remarkable for its large size, handsome shape and bright red color. One of the most profitable crops for the market gardener. It is especially desirable in the home garden. See page 21.

\section{White Tipped Scarlet Radish}

Extremely early variety which has matured fit for the table in twenty days. Is fully grown in less than four weeks. Is of a bright, rich, scarlet color, tipped with white. It has very few leaves, hence is an excellent variety for forcing. Quality is unsurpassed. tender, crisp, appetizing. See page 18.

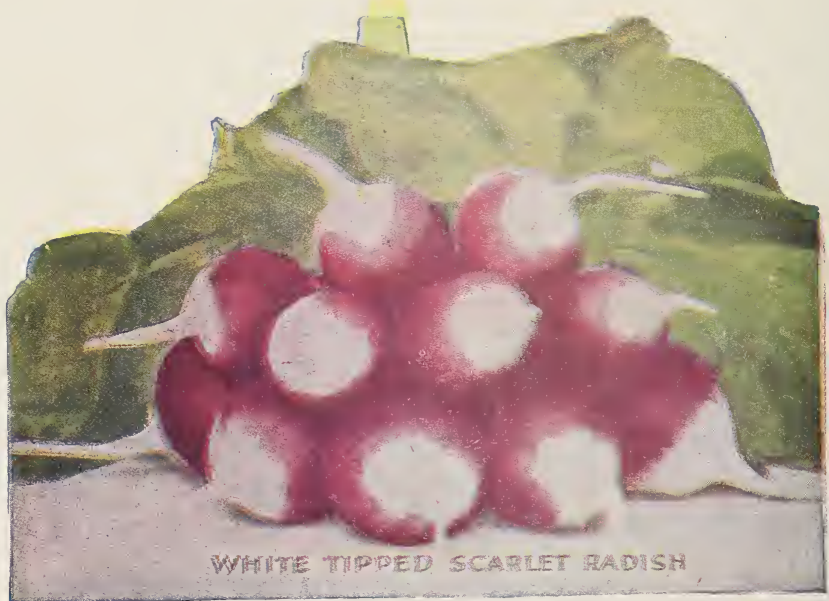




\section{NORTHERN SEED CO.}

VALLEY GITY, NORTH DAKOTA

P'resident, A. P. Peake

Vice President and Manager, A. B. Cox

Secretary-Treasurer, Chas. W. Nelson,

Assistant Secretary-Treasurer, Willie Murphy

We wish to thank the many customers who, by their orders to us, have made it possible for us to offer this our 1920 catalog to the trade.

A successful business must be built upon actual service rendered to the public, and the repeated orders from old customers with the many orders from new ones received the past season lead us to hope that we are, in a measure, reaching our goal by giving each customer prompt service and the best seeds.

Valley City, being upon the main line of the Northern Pacific and Soo railways, gives us excellent shipping connections and we aim to get orders out the day they are received.

We have contracted for seed from the best growers and always keep testing cur stock for germination and ship only high germinating seed of the best quality. For 1920, we are particularly fortunate in having a large supply of home-grown corn, beans, peas, sweet clover and most all of the grains which we catalog. Our stocks of home-grown seeds as men. tioned have been raised from the best seed the market afforded and have been carefully selected, cleaned, cured and tested by ourselves. So we insist that we can furnish the best seed to be had at any price and assure you that the prices we ask are as low as can be made if quality is con. sidered.

Life consists of the habits we form and the farmer and gardener who gets into the habit of waiting until he is ready to plant and then saying "anything is good enough" will have this feeling reflected in the crops produced, while the person who studies conditions and is careful to plant only the best seeds will reap the best crops. There is a narrow margin between failure and success in all of our undertakings and the sure method of reaching success is by starting right. The right way to start farming or gardening is to have the best seed and give it proper care.

We know that our success or failure in business will be determined by the crops our customers receive from the seed we sell them. With this in mind, we say, "Buy our seeds and you have started right."

Send your orders, or write for samples or information early and the best we have, and we believe our best is the best you will get any place, is at your service.

Yours very truly,

NORTHERN SEED COMPANY. 


\section{YOUR 1920 GARDEN}

USE THIS PAGE TO KEEP A RECORD OF YOUR GARDEN. YOU WILL FIND IT CONVENIENT TO HAVE ANOTHER SEASON.

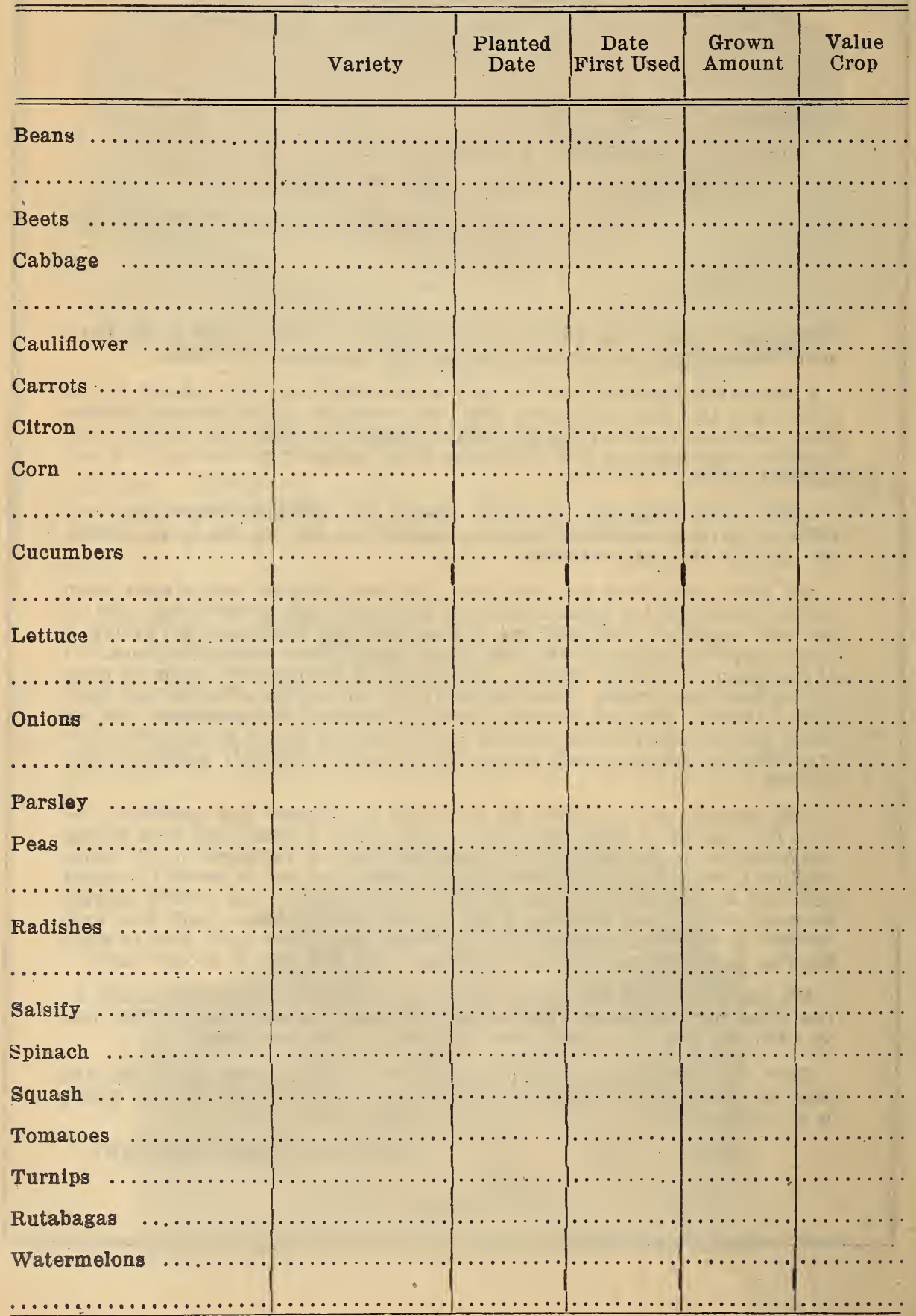




\section{VEGETABLE SEEDS}

\section{ASPARAGUS}

One ounce of seed for 50 feet of row. Four pounds per acre.

This is a very early and most delicious vegetable and should be raised in every per. manent garden. The roots should be grown one year and transplanted into a bed whioh has been deeply cultivated the following spring. This will make a bed which with little further care will produce the first vegetable in the spring for seven or eight years.

To start roots, soak seed well and plant in rows 18 inches apart, covering seed with 2 inches of fine dirt. When plants are 2 inches high thin to 1 inch apart in the row; cultivate frequently through summer and leave in the ground over winter. Next spring set roots 1 foot apart in the row and rows 4 feet apart. The stems may be cut off 3 or 4 times each season and nothing that comes from the ground is better to eat. After the last cutting, cover the bed with manure and leave until next spring.

One ounce of seed will produce 100 plants, which, set into a bed $15 \times 40$ feet, will yield enough asparagus for a family.

Conover's Colossal. This is the best variety for the northwest; the stems are bright green with purple tips and grow to good size. Price, packet 5c, ounce 10c, $1 / 4$ pound $20 \mathrm{c}$, pound $60 \mathrm{c}$, postpaid.

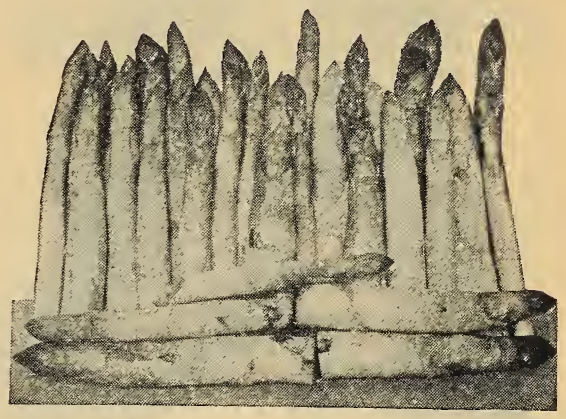

Conover's Colossal.

\section{BEANS}

One ounce to 60 feet of row.

Beans should be planted after danger of frost is over in the spring and will grow upon any kind of soil. Field beans are raised upon land too poor to raise grain crops and the bean roots leave the soil in better condition than when beans were planted.

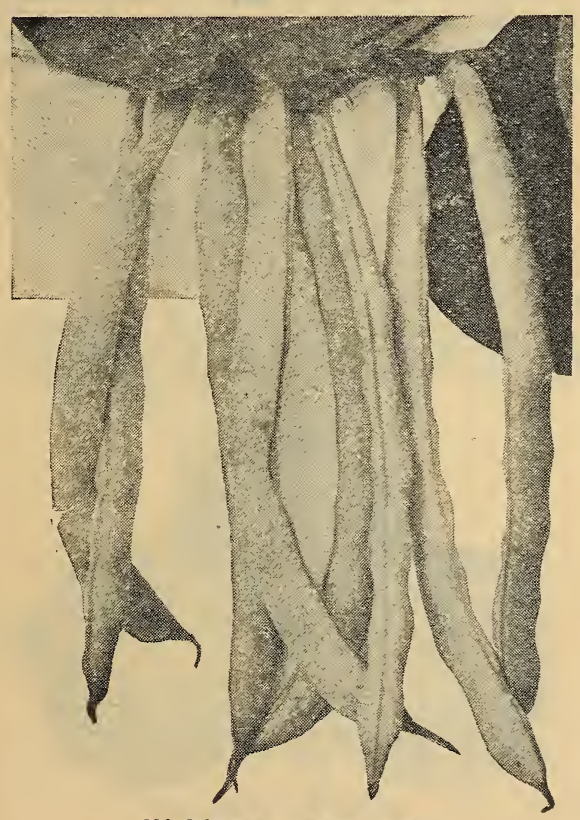

Wichigan White Wax.
Michigan White Wax. A very early dwarf snap bean yielding a nice crop of yellow podded beans uniform in size. Thoy have excellent flavor and retain their shape and color when being cooked, making a very desirable table product. Price, packet 10c, $1 / 4$ pound $20 \mathrm{c}, 1 / 2$ pound $30 \mathrm{c}$, pound 50e, 5 pounds $\$ 2.25$, postpaid.

Golden Wax. As its name Indicates, a healthy golden pod free from rust. This is a standard variety, producing a large number of long round pods which are practically stringless at all times. The pods are very brittle, but keep a long time upon the vines.

We have an exceptionally fine stock of this bean which was raised in this county from acclimated seed which we offer at: Price, packet $10 \mathrm{c}, 1 / 4$ pound $15 \mathrm{e}, 1 /$ pound $25 \mathrm{c}$, pound $40 \mathrm{c}$, 5 pounds $\$ 1.75$, postpaid.

Black Wax. Not quite so early as Golden Wax, but produces a larger crop of heavier pods which are very tender and stringless. The vines grow about 16 inches high and the pods are well up from the ground. We offer home-grown seed of perfect germination at: Price, packet 10e, $1 / 4$ pound $15 e, 1 / 2$ pound $20 c$, pound $30 c, 5$ pounds $\$ 1.25$, postpaid.

Extra Early Red Valentine. This is much used by market gardeners, as it is the earliest produoer (edible pods in 5 weeks being a common growth) and the bright green pods are attractive while the crop is heavy. We recommend this as a first crop bean. Price, packet 10e, $1 / 4$ pound 15e, $1 / 2$ pound 25e. pound 35e, s pounds \$1.50, postpald. 


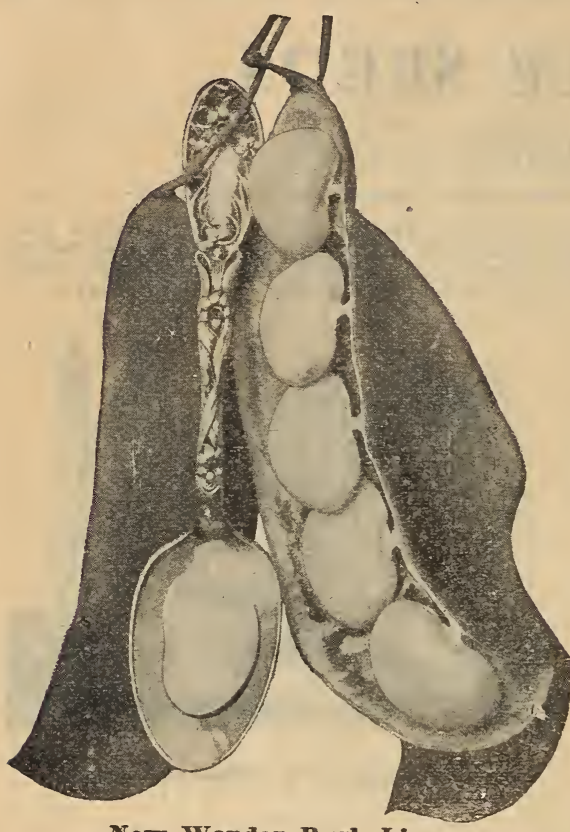

New Wonder Bush Lima.

Long Yellow Six Weeks. A green podded dwarf bush bean named for the color of the seed and the time required to produce a crop. Has long, stralght, heavy pods which are of excellent quality, especially when young. Many of our customers have bought this bean for several years and their repeated orders convince us that there is great merit in the crop. Price, packet 10c, $1 / 4$ pound $15 \mathrm{c}, 1 / 2$ pound $25 \mathrm{c}$, pound $40 \mathrm{c}, 5$ pounds $\$ 1.85$, postpaid.

Many of our customers believe and say that a pole bean has no equal in the garden and we offer the best of many varieties.

Kentucky Wonder. This is not quite so early as the dwarf beans and requires poles or trellis, but repays for the extra effort in a strong, healthy crop of pods. often 10 inches long. If the pods are kept picked the vines will continue to bear for a long season. Price, packet 10c, 1 pound 15c, $1 / 2$ pound $25 \mathrm{c}$, pound $40 \mathrm{c}$, postpaid.

Lima beans are different from the other varieties in that they yield a much larger bean with a flavor distinct from any other kind. Many people prefer this to the others.

After repeated trials we offer the lima bean best suited to our conditions of soil and climate.

New Wonder Bush Lima. Price, packet 10e, $1 / 4$ pound $15 \mathrm{c}$, $1 / 2$ pound $20 \mathrm{c}$, pound $35 \mathrm{c}$, postpaid.

While string beans are used as picked or must be canned for winter use, fleld beans are threshed at leisure and may be kept for years and used at any time. They are one of the best foods produced and will to a considerable extent help to keep down the cost of living, as they are an excellent substitute for meat.

White Navy. We offer an excellent stock of home-grown, hand-picked, high germination seed of this old favorite (often called the Army Bean because the government found no food their equal and used them very extensively) at following prices: Packet 5c, $1 / 4$ pound 10c, 1/2 pound $15 \mathrm{c}$, pound $25 \mathrm{c}, 5$ pounds $\$ 1.10$, postpaid.

Great Northern. This is a North Dakota strain of the white navy bean which combines all of the good quallties of the old stock with a heavier yield of better flavored bean which matures a little earlier. WE FEEL that this is a real improvement upon the old stock and offer a supply of home-grown, carefully selected seed at: Price, packet 5c, $1 / 4$ pound $15 \mathrm{c}, 1 / 2$ pound $25 \mathrm{c}$, pound $40 \mathrm{c}, 5$ pounds $\$ 1.50$, postpaid.

1200 to 1 . This is a new variety which resembles the navy bean in color and flavor, but is slightly larger. The lady from whom we obtained our stock writes: "They are a wonderful yielder. I planted 135 beans last year and harvested 12 pounds of dry seed-last year the first of this seed was offered in this country." In planting this bean put but one seed in each hill, as the vine spreads to more than 2 feet across and yields, as the name indicates, 1200 for 1 . Price, packet 10c.

\section{BEETS}

One ounce of seed to 50 feet of row. Five pounds per acre.

Beets may be planted from early spring until midsummer and will yield a delightful supply of cholce vegetables through the entire season as well as a supply for winter use. Rows should be 18 inches apart and plants thinned to six inches apart for winter beets.

Detroit Dark Red. This is the old gen. eral favorite and whlle not so early as some varieties, produces a wonderful crop of large, frm roots of globe shape with deep red meat. It is particularly suited for canning. Price, packet 5c, ounce $10 \mathrm{c}$, $1 / 4$ pound $40 \mathrm{c}$, $1 / 2$ pound $75 \mathrm{e}$, pound $\$ 1.25$. postpaid.

Crosby's Egyptian. An improved strain which has a slightly flattened root with zoned red and white flesh. The young tops and beets make very flne greens. Priee, packet 5c, ounce 10c, $1 / 4$ pound $40 \mathrm{c}$, $1 / 2$ pound $75 c$, pound $\$ 1.25$, postpaid.

Early Eclipse. The earliest of the flock. A firm globe root not so large as the others and lighter colored, but firm meat and can be used 45 days after planting. Price. packet $5 e$, ounce $10 c$, $1 / 4$ pound 40e. $1 / 2$ pound Fe, pound \$1.15. postpaid.

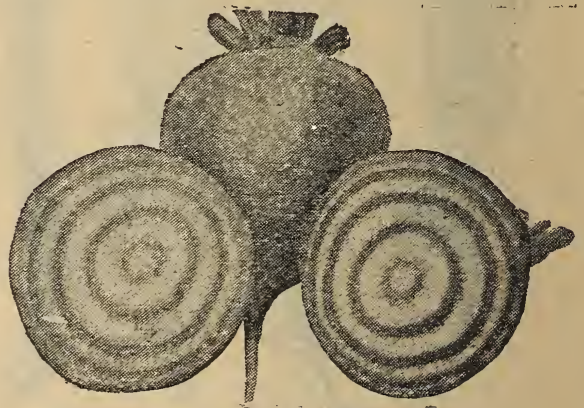

Farly Hilood Turnip. 
Long Smooth Blood. A deep dark red root of delicious flavor and an exceptionally good keeper for winter storage. The long, slender roots grow largely under the ground, being about 10 inches long and 2 inches across at the top. The root is very firm and while ready for table in 60 days will produce more than 10 tons per acre of ripe roots. Price, packet 5e, ounce 10e, $1 / 4$ pound $40 \mathrm{e}, 1 / 2$ pound $75 \mathrm{e}$, pound $\$ 1.25$, postpaid.

Early Blood Turnip. The best red turnip beet for home or market garden. A handsome root with small top. Its early maturity, excellent root and splendid shape and color make it a favorite with every one who plants it. More of this beet is planted by old gardeners than any other variety and you will surely be satisfied with the crop from the seed which we offer. Price, packet 5e, ounce 10c, $1 / 4$ pound $40 \mathrm{e}, 1 / 2$ pound $75 \mathrm{c}$, pound $\$ 1.25$, post paid.

\section{Swiss Chard}

This is a little known member of the beet family. But once raised in the garden will always be planted afterwards. It produces more food and is available over a longer time than any other garden product. The leaves make better greens than spinach and may be cut early and late. When the leaves are too large for greens, the large broad stems and midribs are used as asparagus. Try a small bed this year and we are certain that you will plant more next season. Price, packet 5c, ounce 10e, $1 / 4$ pound 30c, $1 / 2$ pound 50c, postpaid.

Northern Seed Co., Valley City, N. D.

I have to send to you for a good many dollars worth of seed and I never used better seeds.

White Earth, N. D.

Mrs. Will Cole.

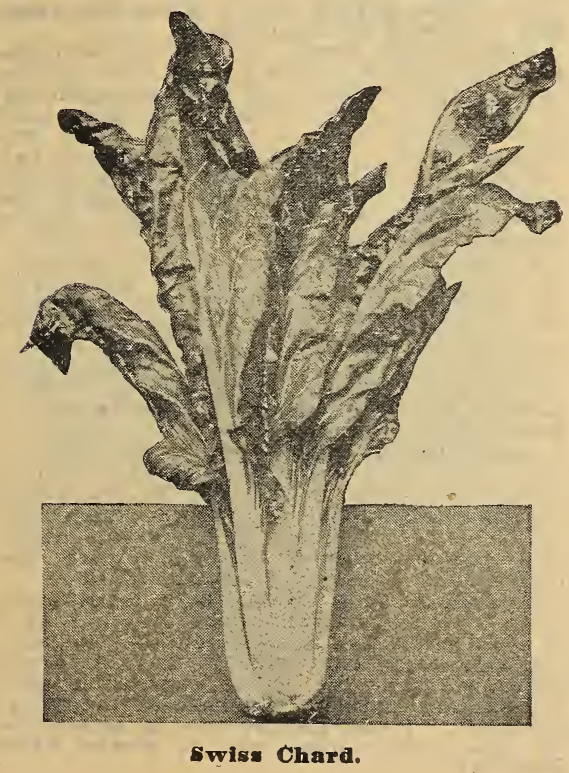

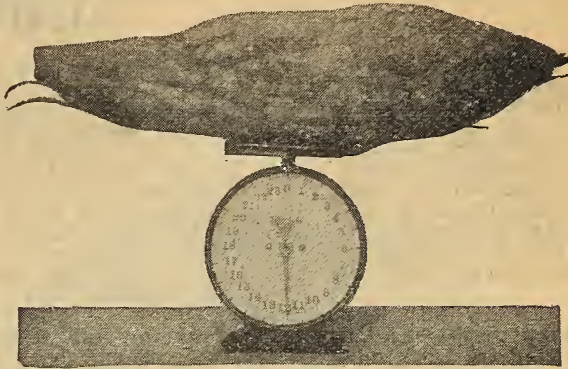

Mamimoth Long Red.

\section{Sugar Beets}

During the past season the entire country went through a severe shortage of sugar caused by failure of crops where the bulk of our sugar is produced. Here in the Northwest we may avoid this situation and save considerable money by producing sugar beets from which our supply of sugar may be made. The beets will grow any place common garden produce can be raised. Twelve to 18 tons of roots per acre is the crop to be expected and 40 pounds of beets make 5 quarts of syrup. The Department of Agriculture Farmer's Bulletin 823 describes a simple method of home refining. Send for this bulletin, plant a patch of su: beets and be independent of the sugar barons. Price of seed, packet 5e, ounce 10e, $1 / 4$ pound $40 \mathrm{e}$, $1 / 2$ pound $75 \mathrm{e}$, pound $\$ 1.30$, postpaid.

\section{Mangel Wurzel}

North Dakota and the entlre Northwest have decided that the day of exclusive grain farming is over, and to be a successful farmer a man must diversify and raise cattle. No acre of any other crop that may be raised in this country will yield the amount of feed for cattle that can be gotten from an acre of Mangel Wurzels and they require little more cultivation than corn and leave the ground in better shape than corn. Thirty tons per acre of most succulent roots are often raised. Mangels have a high feeding value and are particularly valuable because they act as a tonic, or condition powder, particularly if fed to stock receiving all dry feed.

Improved Mammoth Long Red. Roots are straight and very solid; red outside, rose tinted within. The heaviest producer of all. Price, packet 5c, ounce 10c, $1 / 4$ pound $30 \mathrm{c}$, $1 / 2$ pound $60 \mathrm{e}$, pound $\$ 1.20$, postpaid.

Improved Golden Tankard. The best for milch cows. Especially fine for cows because they will increase the flow of milk and do not taint it as many roots. A rich orange root which is a good keeper. Price, packet 5c, ounce $10 \mathrm{c}, 1 / 4$ pound $30 \mathrm{e}, 1 / 2$ pound $60 \mathrm{e}$, pound $\$ 1.20$, postpaid.

Giant Half Sugar. The root is adapted for feeding cattle that are being fatted, or young stock which is growing. The flesh is white and particularly rich in sugar. Price, packet 5c, ounce 10c, 1/4 pound $35 c$, $1 / 2$ pound $65 c$, pound $\$ 1.25$, postpaid. 


\section{CABBAGE}

When Napoleon Bonaparte threatened to rule the entire world, there were well established seed farms in Denmark. These farms have been handled by men who have made a life work of growing cabbage seed ever since that time.

Our stock of cabbage and cauliflower is raised especially for us by one of the firms operating seed farms there and shipped direct to us from Copenhagen.

Denmark being much farther north than our territory, gives us seed which will bring crops which will mature faster than crops from domestic seed. The scores of years experience in selection and breeding seed which is utilized by the growers there malke the imported seed more true to type and of better quality than the domestic production. You will possibly find cheaper cabbage seed than what we offer, but the crop from cheaj seed will be much more costly than the crop from our seed-which we know is the kest. One ounce will produce 2,500 plants.

Everybody knows that cabbage is one of the staple vegetables of almost every civil. ized people and the only question asked about planting is which kind is best. We have tried out the many varieties offered by the seedsmen of the world and offer the kinds which have shown the most satisfactory results.

Pride of North Dakota. In $1916 \mathrm{we}$ introduced this splendid cabbage to the trade, after testing it out thoroughly, and we are very proud of the result. It is not as early as the Jersey Wakefield, but produces a much larger head-10 pounds with ordinary care and conditions. The heads are ball shaped, solid and firm, with a small core and fine leaves very closely folded. You will make no mistake in ordering this seed for your main cabbage crop. Price, packet 25c, $1 / 2$ ounce 50c, postpaid.

Copenhagen Market. This has been the main crop of the European gardeners for generations. Not the earliest, but the one which produces the most uniform crop of compact round heads of good size which do not crack open. Grows close to the ground and has very few outer leaves. The kraut of Europe is made of this cabbage and you will be well pleased if you depend upon the crop from our seed for your supply. Price, packet 10c, $1 / 2$ ounce. 50e, ounce $80 \mathrm{c}, 1 / 4$ pound $\$ 2.25$, postpaid.

Farly J e r sey Wakefield An early pointed head of the sweetest leaves found upon any cabbage plant. The heads aie not as large as many kinds, but the Jersey Wakefield will develop a good head where the other sorts fail because the Wakefield is hardier and stands drought better than any other kind upon the mar. ket. Price, packet 10c, $1 / 2$ ounce 35c, ounce $60 \mathrm{c}, 1 / 4$ pound $\$ 1.75$, postpaid.

Early Winningstad. The cabbage to plant if you want the first in the country to be fit for use. The heads are pointed, weigh 5 or 6 pounds, and are very hard. This makes a fair keeper, but it is a first crop cabbage and stands much cold and

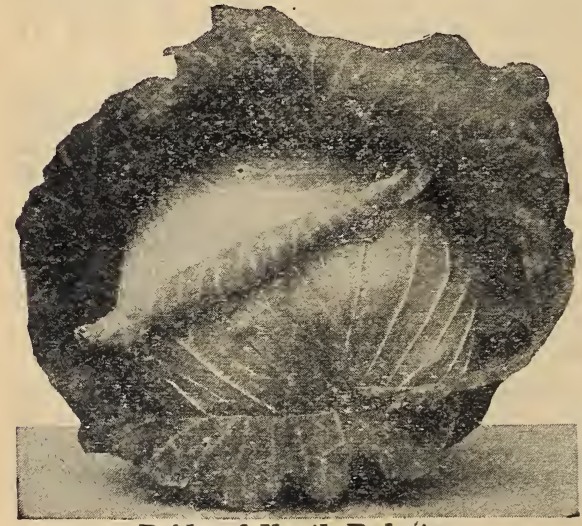

Pride of North Dakota.

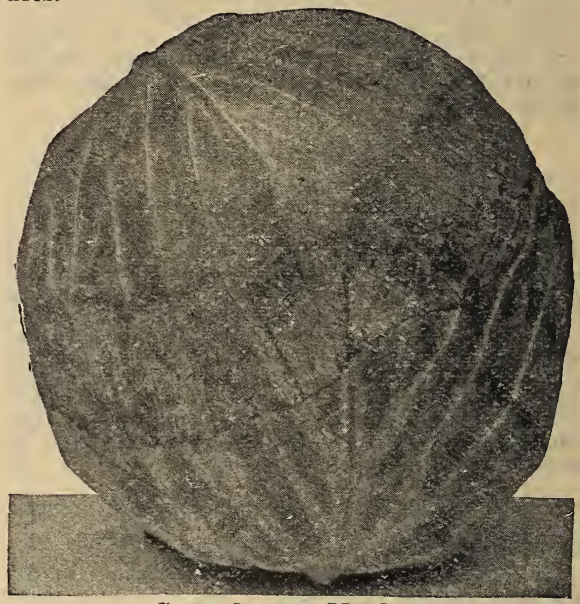

Copenhagen Market.

resists bugs better than the other varieties. Price, packet $10 \mathrm{c}, 1 / 2$ ounce 35e, ounce $60 \mathrm{c}, 1 / 4$ pound $\$ 1.75$, postpaid.

Danish Ball Head. One of the well-developed strains which grows upon a long stem; has a ball-shaped head, exceptionally hard and crisp, which will keep until next season's crop is ready if given reasonable care. It stands heat and cold botter and will not rot as soon as the shorter varieties of cabbage. Price, packet 10e, $1 / 4$ ounce $20 \mathrm{c}, 1 / 2$ ounce $30 \mathrm{c}$, ounce $50 \mathrm{c}, 1 / 4$ pound $\$ 1.50$, postpaid.

Premium Flat Dutch. "The kind mother used to grow" and father hung it in the cellar and the entire family ate it all winter and next spring. It is slower than most varieties, but will ripen any ordinary season into the finest large flat heads of most splendid keeping quality. Price, packet 10c, $1 / 4$ ounce 15e, $1 / 2$ ounce $25 c, 1 / 4$ pound $\$ 1.25$, postpaid.

Large Drumhead. Many of our customers insist upon having this old favorite which has been known for 50 years and still produces a deep, middle-sized head which is unsurpassed for cooking qualities. Price, packet 10c, $1 / 4$ ounce 15e, ounce $40 \mathrm{c}$, $1 / 4$ pound $\$ 1.25$, postpaid.

Mammoth Red Rock. This is different from all the sorts listed before in that it is a red cabbage. It is much used in making salads, as the color is attractive and different from the usual vegetables used for salads. This is the best of many red varieties. Price, packet 10c, $1 / 4$ ounce $15 c$. $1 / 2$ ounce $25 c$, onnce $40 c$, $1 / 4$ pound $\$ 1.50$, postpaid. 


\section{CAULIFLOWER}

One ounce of seed, will produce 2,500 plants.

While this is one of the most delicious vegetables taken from the ground few people raise it in the home garden, usually because someone has said that cauliflower was hard to raise. This is a mistake, as while cauliflower is a little slower and requires more care than cabbage, any place that cabbage may be grown, cauliflower will mature.

Cauliflower ripens in 90 to 120 days from time of planting and does not head well during hot weather. For this reason two crops of cauliflower should be raised-one to mature before the heated season and the other to ripen late in $\mathrm{Au}$ gust or September, after the hottest days. Start plants for the first crop indoors and transplant into the garden 18 inches apart in rows 3 feet apart. They will stand a slight frost better than cabbage. The plants for the second crop may be started in a bed in the garden and transplanted as the flrst crop. When the head commences to form, gather the leaves up around it and fasten them together that the head may bleach. The heads should be cut off before they start to branch.

Danish Giant or Dry Weather. This produces a stone hard head upon a dwarf stem and the strain has been particularly developed to mature with a small amount of rainfall. In fact, it will produce a fair crop where other varieties fail because of lack of moisture. Price, packet 15c, 1/2 ounce $\$ 1.25$, ounce $\$ 2.25$, postpaid.

Extra Early Dwarf Erfurt. An old, well-establshed kind-not quite so early as Snowball, but will start out of doors and yields a very superior head of medium size. This has been a general favorite with market gardeners for many years. Price, packet $15 \mathrm{c}, 1 / 2$ ounce $\$ 1.00$, ounce $\$ 1.75$, postpaid.

Snowball. The quickest producing variety of all. It starts better indoors or under glass than other kinds and the heads are very uniform -8 to 10 inches in size-snow white and exceptionally flrm. Price, packet 15c, $1 / 2$ ounce $\$ 1.25$, ounce $\$ 2.00$, postpaid.
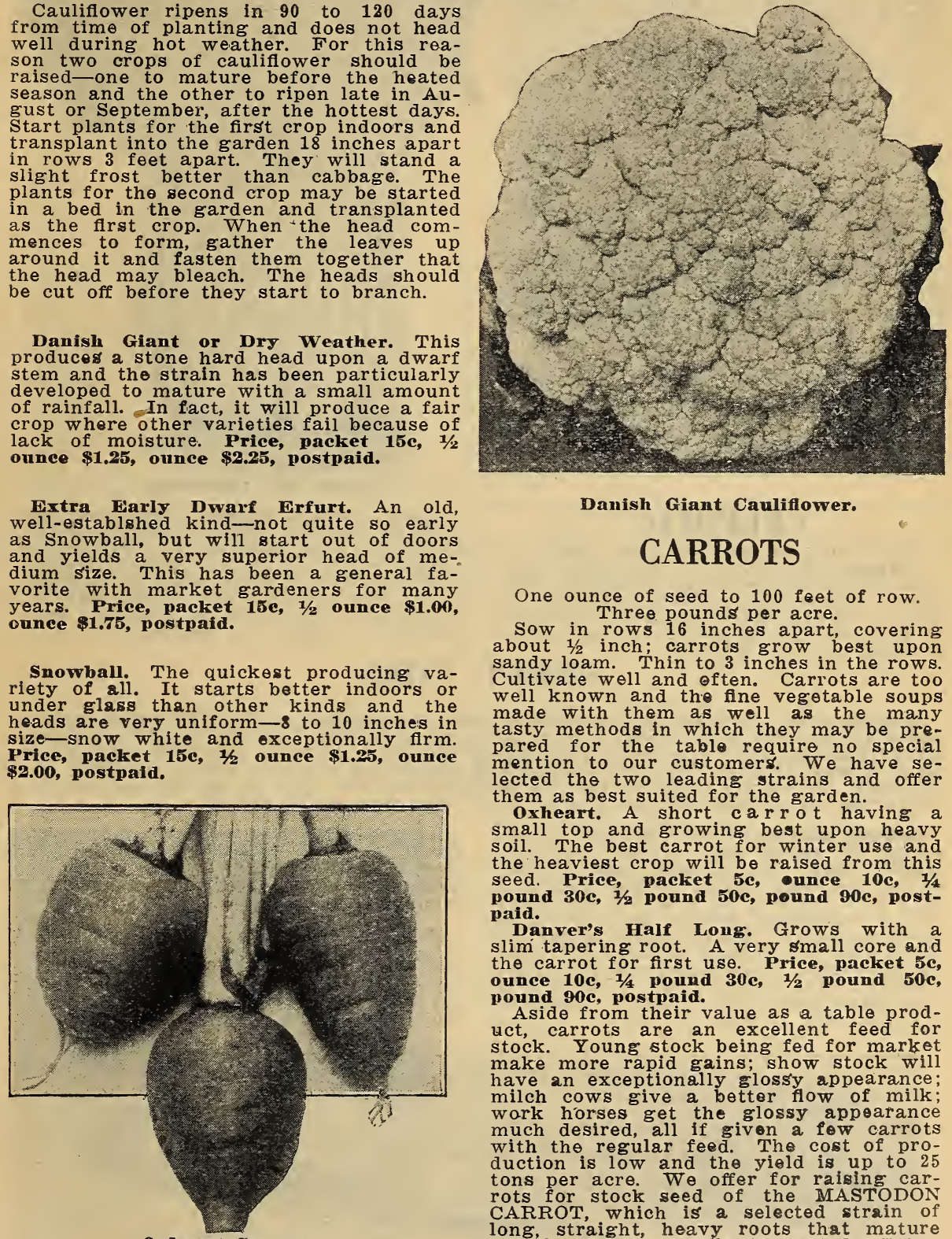

Danish Giant Cauliflower.

\section{CARROTS}

One ounce of seed to 100 feet of row. Three pounds per acre.

Sow in rows 16 inches apart, covering about $1 / 2$ inch; carrots grow best upon sandy loam. Thin to 3 inches in the rows. Cultivate well and often. Carrots are too well known and the fine vegetable soups made with them as well as the many tasty methods in which they may be pre. pared for the table require no special mention to our customers. We have selected the two leading strains and offer them as best suited for the garden.

oxheart. A short carrot having a small top and growing best upon heavy soil. The best carrot for winter use and the heaviest crop will be raised from this seed. Price, packet 5c, ounce 10c, $1 / 4$ pound 30e, $1 / 2$ pound 50c, pound $90 \mathrm{c}$, postpaid.

Danver's Half Long. Grows with a slim tapering root. A very small core and the carrot for first use. Price, packet 5e, ounce $10 \mathrm{c}, 1 / 4$ pound $30 \mathrm{c}, 1 / 2$ pound $50 \mathrm{c}$, pound 90c, postpaid.

Aside from their value as a table product, carrots are an excellent feed for stock. Young stock being fed for market make more rapid gains; show stock will have an exceptionally glossy appearance; milch cows give a better flow of milk; work horses get the glossy appoarance much desired, all if given a fow carrots with the regular feed. The cost of production is low and the yield is up to 25 tons per acre. We offer for raising carrots for stock seed of the MASTODON CARROT, which is a selected strain of long, straight, heavy roots that mature rapidly and are easily harvested. Price. packet $5 e$, ounce $10 \mathrm{c}, 1 / 4$ pound $30 \mathrm{c}$, pound Doc, postpaid. 


\section{CELERY}

Celery requires more work than most vegetables, but the crop is well worth the extra effort. Plants should be started in the house, in March, and transplanted into trenches about a foot deep when plants are 3 or 4 inches high. The plants should be well watered when transplanted and the dirt kept around the stems as the plants grow. This hilling is done that the plant may blanch as it grows. The blanched stems are much better tasting than if allowed to grow exposed to the weather.

White Plume. The earliest variety we know. It grows rapidly and will blanch in a short time when hilled. It is not quite so large as other varieties, but is desirable because it is earlier. Price. packet $10 \mathrm{c}$, ounce $30 \mathrm{c}, 1 / 4$ pound $\$ 1.00$. postpaid.

Golden Self Blanehing. A few days later than White Plume, but it produces a much heavier plant of thick, crisp stems, making a very choice crop of unsurpassed celery. Price, packet 10c, ounce 50c, $1 / 4$ pound $\$ 1.75$, postpaid.

Giant Pascal. The celery to plant if you want a large crop of heavy celery with an exceptionally large heart. It is not so quick to develop as the other kinds, but has larger bunches and is the best keeper of all. Price, packet 10c. ounce 35e, $1 / 4$ pound $\$ 1.25$, pound $\$ 4.00$, postpaid.

\section{CELERIAC}

One ounce of seed for 1,000 plants.

Culture. Start at the same time and give the same treatment as celery. Cultivate thoroughly. Plants require no hilling. When the roots have a diameter of 2 inches they are ready to use. Pack in damp sand for winter.

\section{SWEET CORN}

Nothing from the garden gives quite so much satisiaction as the first "roasting ed:s" and a small patch will furnish a most delicious vegetable from the middle of Augusi until freoze-up time. We have a particularly fine stock of sweet corn this year-nearly all of it was raised in this county and all is acclimated and tests better than $90 \%$ germination. So we feel confident that we do not exceed the truth by saying that our sued will bring the earliest and best crop of sweet corn that can be raised.

Golden Bantam. This is the newest strain of sweet corn which has been placed upon the market and nothing which has been offered to the trade met with such approval as this corn did. Many of our customers declare that it is as much superior to the old kinds as the old kinds were better than ordinary field corn for table use. The stalks grow 4 to 5 feet high and have 2 cobs about 6 inches long upon each stalk. It is early maturing and the corn is good to eat for a long

time after the first may be picker. have home-grown seed of 95 per cent germination which we offer at: $\mathbf{P}$. packet 10c, $1 / 2$ pound $20 \mathrm{c}$, pound 3\%s, 5 pounds \$1.50, postpaid.

Peep o' Day. The earliest sweet corn Produces several ears upon each stalk of corn which cooks almost white and is very toothsome. This corn is much used for canning. Price, packet 10e, $1 / 2$ ponus! 20 , pound 35 e, 5 pounds $\$ 1.50$, postpaid.

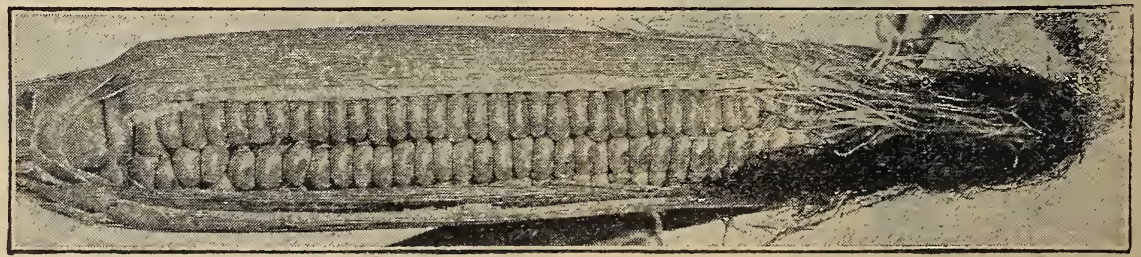

Golden Bantam. 


\section{Chinese Wool Flower}

The plants are tender and should be started indoors and transplanted after frost season is over; protect the transplanted shoots by putting a can or stiff paper around them for a week or more-until the roots become firmly set.

Each stem grows two and a half or three feet high and soon starts blooming with a center head, often six inches across. Then a score or more branches grow out of each main stem and each branch bears a ball of scarlet wool; all the branches

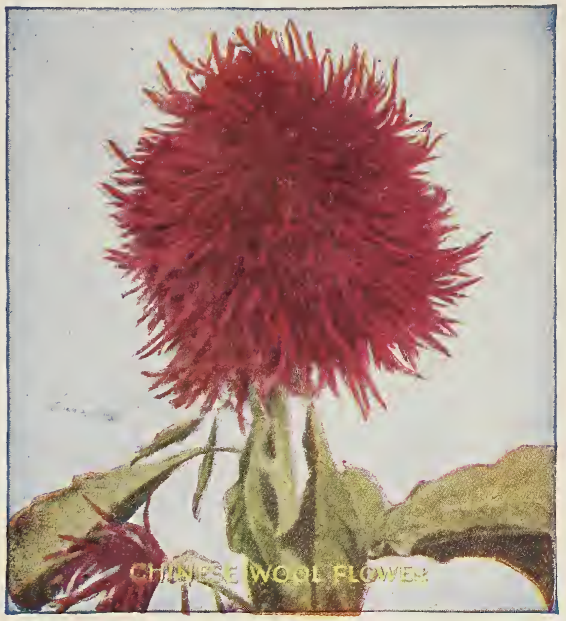
support numerous laterals with small heads of bloom mixed with foliage, so that the plants each look like a splendidly arranged bouquet set into the ground. None of the blooms fade in any way until frost comes in the fall but continue to expand and glow with a deepening richness of color-a dark crimson scarlet. A row of plants set one foot apart along a path or bed makes a very handsome hedge. You will be well satisfied with the result if you plant some of these. Price: Pkt. 25c postpaid.

\section{Asters}

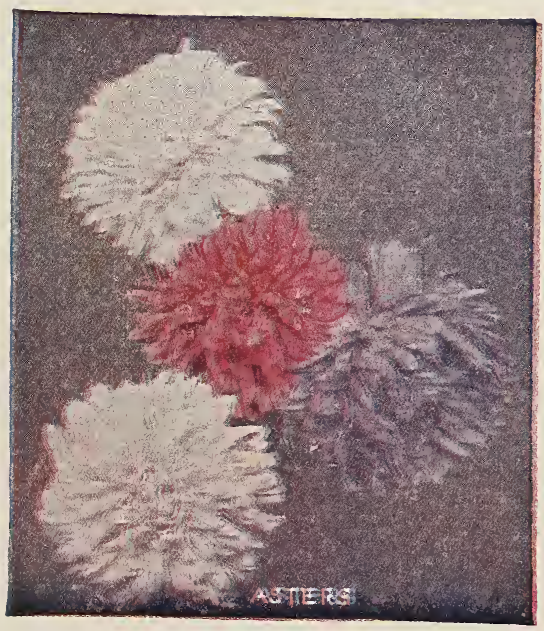

This beautiful flower is being constantly improved, and is now one of the most desirable and effective of our garden beauties. As a bedder it is beyond description, as large beds of these lovely flowers greet you everywhere. Indispensable for cut flowers, fine as pot plants and great to show at fairs and exhibitions.

We offer a mixture of all the best varieties of asters suitable for cut flowers consisting principally of white, pink and the brightest red, with a small proportion of blue and purple and intermediate shades. It is a good substitute for the higher priced separate colors. See page 23. 


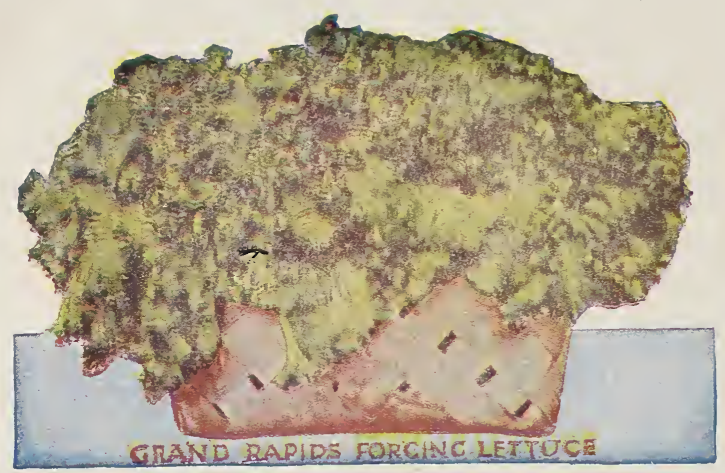

\section{Grand Rapids Lettuce}

As many as fifty large green houses at Grand Rapids, Michigan, are devoted to forcing this lettuce in winter. The growers have distanced all competitors, obtaining the highest prices in the markets. Of superior quality and beautiful appearance, Grand Rapids is a strong grower, also garden variety. See page 11.

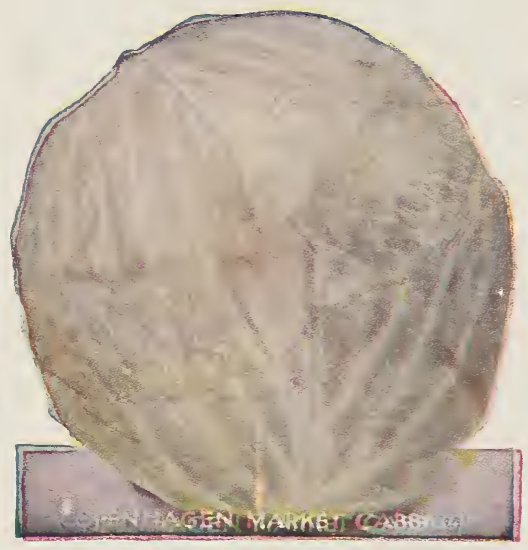

\section{Copenhagen Market Cabbaze}

A new early variety. Very popular with market gardeners. The heads average about ten pounds each in weight, are hard and solid with small core. The quality is extra fine and sweet. It is a short stemmed variety, the heads nearly resting on the ground. The leaves are rather small and tightly folded, making it possible to set them close together in the field. See page 6 .

\section{Nott's Excelsior}

The earliest and best dwarf wrinkled pea. Fast taking the place of American Wonder. It is early, while the pods are large, numerous. and well filled. The peas are tender and of a most delicious flavor when cooked. See page 16.

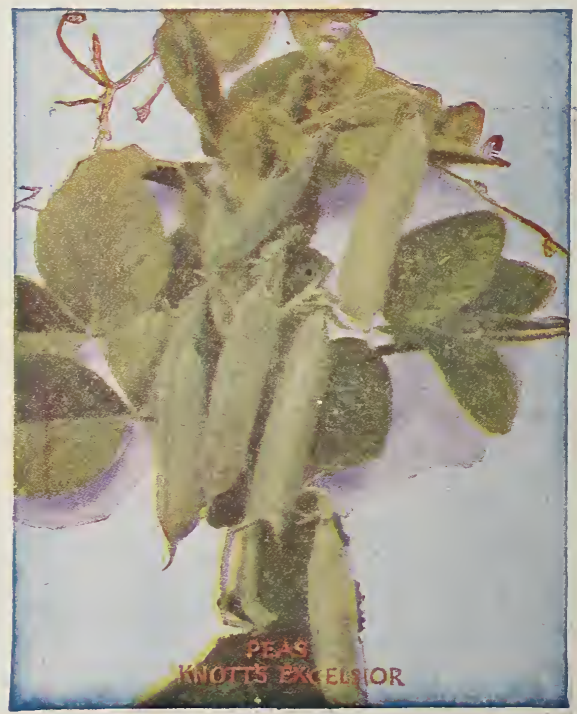


iarly Minnesota. A well-known standvariety, not quite so early as Peep o' $\checkmark$, but produces a much larger ear of ow corn. Price, packet 10e, $1 / 2$ pound pound 35e, 5 pounds $\$ 1.50$, postpaid.

Vhite Cob Cory. An old favorite which many friends. A very large white ear d from tip to butt with broad, deepgrains which are sweet and tender. ce, wacket $10 \mathrm{c}, 1 / 2$ pound $20 \mathrm{c}$, pound $35 \mathrm{e}$, ounds $\$ 1.50$, postpaid.

onntry Gentleman. A late-maturing, cious corn. Stalks grow 5 to 7 feet and have 2 to 5 cobs each. The ker- rels have no regular arrangement and this corn is called "Zig Zag" by some seedsmen. Price, packet. 10c, 1/2 pound 20e, pound $35 c, 5$ pounds $\$ 1.50$, postpaid.

Black Mexican. A corn which is different from the others. The seed is black and the corn when fit to eat is white, but darkens as it ripens. It is later than the other varieties we list, but the corn is very sweet and no better tasting corn can be raised. We have a supply of homegrown seed which is well cured and shows perfect germination. Price, packet 10e, $1 / 2$ pound 20c, pound 35e, 5 pounds \$1.50, postpaid.

\section{POP CORN}

he young people of the family, and en the older ones too, are better at ae than "running" around" and will stay home if some sttraction is provide 1 . more healthful attraction can be of ad during the long fall and wint $=r$ nings than popping and eating a pan pop corn. And, if the corn has been ie raised, another feature is added $i$. the attraction. Fop corn is easily digested and takes the place of candy which costs much money and is not healthful. It is easily grown and every garden should have, at least, a few rows of pop corn. We offer home-grown seed which we are positive will ripen any ordinary season Price, packet 5e, 1/2 pound 15e, pound 25e. postpaid.

\section{CUCUMBERS}

ot how much we make, but how much we save determines our financial standing. : amount the average family saves is largely determined by the cost of living. Every$1 \mathrm{~g}$ which is raised in the garden and eaten takes the place of something which would bought at the highest prices the world ever knew. A dozen hills of cucumbers will nish a much relished vegetable for the table during two months of the summer and

cucumbers not eaten green make the best pickles it is possible to have.
ut 10 seeds in each hill and have hills

eet apart each way. Unless the ground rich, put a shovelful of manure into $h$ hill and put earth over the manure which to plant the seed. When th. nts start leave 4 or 5 of the sturdiest wing in each hill and cultivate well l often. Cucumbers should be picke.t fast as they reach good size, as a vine 1 stop bearing as soon as fruit is a ed to ripen upon it.

iarly Fortune. P r o d u ces a large. oth fruit, green in color. While not te so early as some varieties, the fruit l keep fresh a longer time than the ers we list. For this reason it is much d for growing table cucumbers. Price, het 5e, ounce 10c, $1 / 4$ pound 30c, pound Ho, postpaid.

mproved Long Green. The largest its-often 15 inches long-are raised n this variety. Used for slicing green put into mixed pickles that are pped. Price, packet 5e, ounce 10c, 1/4 nd 30e, pound $\$ 1.00$, postpaid.

mproved Early Frame. This raises a se crop of short, heavy fruits which $y$ be used for either table or pickling. rou plant but one variety of cueumber want both green cucumbers and rles, plant this kind. Price, packet ounce $10 \mathrm{c}, 1 / 4$ pound $30 \mathrm{c}$, pound $\$ 1.00$. tpaid.

oston Pickling. The kind to plant if want a large number of mediumd, round, firm cucumbers for pickling. ee, packet sc, ounce $10 c$, $1 / 1$ pound 30c, nd 90e, postpaid.

arly Cluster. Produces its fruits in iters of 2 or 3 upon a single branch. vines bear a large number of clusters are desirable for sweet pickles, or place a small cucumber is wanted. se, packet 5e, ounce 10c, $1 / 1$ pound 25e, nd 90c, postpaid.

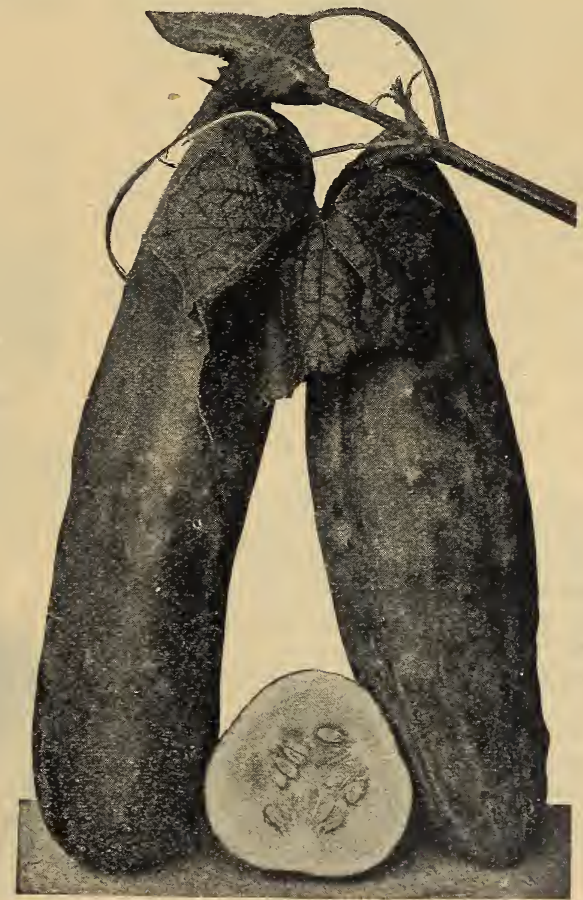

Early Fortune Cucumber. 


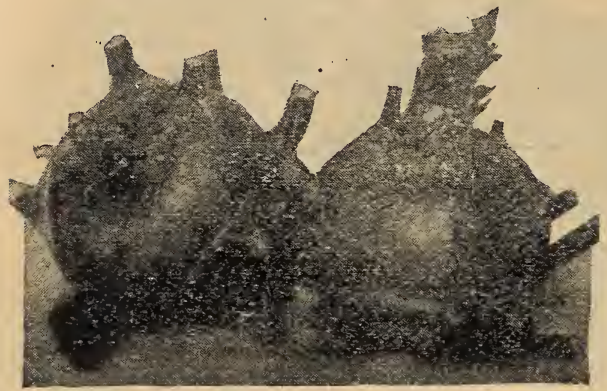

Kohl Rabi.

\section{KALE}

One ounce for 200 feet of row.

Plant in rows 16 inches apart; thin as lettuce and leave the plants in the garden until nipped by frost for winter use. Then pull it and hang in the cellar. It may be cooked for greens, being especially fine with smoked meat. The green leaves make a pretty garnish for any dish.

Tall Scotch Curled. A finely curied, low spreading variety which is very hardy. Price, packet 5e, ounce $20 \mathrm{c}$, $1 / 4$ pound $75 c$, postpaid.

\section{GOURDS}

The old saying was, "Work while you work, and play while you play," but a few gourds raised in the garden combine work and play. They are not a food, bi:t the handsome vines and blossoms with the many peculiar. gourds afford much pleas. ure, while the gourds are put to many different uses when ripe. Plant them as you do cucumbers and train the vines the direction you want them to grow.

Dish Cloth. The center of the fruit is a bunch of fibers which may be used as a dish cloth when dried. Price, packet 5r, ounce 15e, postpaid.

Dipper. The shell is shaped like a dipper and when dried and cleaned makes a novel dipper. Price, packet 5e, ounc: postpaid.

Japanese Nest Wgg. Produces a fruit about the size and shape of an egg. The dried gourds are used for nest egos or stocking darners. Price, packet 5e, ounec 15c, postpaid.

Mixed. Some of all kinds. Price, packet sc, ounce 15c, postpaid.

Northern Seed Co., Valley City, N. D.

Enclosed please find order for more seeds, also check enclosed for payment of same. I received my first order and am more than pleased. Such prompt service I never got from any other seed house.

Very truly yours,

Mrs. F. La Page.

\section{KOHL RABI}

One ounce of seed for 300 feet of row.

This is a little known vegetable which will mature any place cabbage can be grown and makes a welcome variety for the table. It grows more like a turnip than cabbage, being a bulb which is formed above the ground, but combines the good qualities of both cabbage a turnip. The seed should be sown early in the spring-frost does not hurt it-in rows 18 inches apart and thinned to 6 inches in the row. It is ready for use ahead of cabbage and is cooked like cabbage. If a number of plantings are made it may be a part of the vegetable supply through the entire summer.

Early White Vienna. This is the variety best adapted for our territory. Price, packet 5e, ounce $20 c, 1 / 4$ pound $70 c$, postpaid.

\section{ENDIVE}

One ounce for 200 feet of row.

The leaves, which somewhat resemble lettuce, may be cured and then become nearly white and keep crisp for a long time. This makes them fine for salads when no greens are available. Plant in rows 16 inches apart and thin to 12 inches in the row. The small plants pulled when thinning may be used as lettuce is used.

Moss Curled. Grows a dense, compact head of crisp, tender leaves. Price, packet 10e, ounce 15e, $1 / 4$ pound 50c, postpaid.

\section{EGG PLANT}

This is a very desirable vegetable, but requires much care. The seed is of very slow germination and should be started indoors and transplanted after the warm weather has settled, as the plants will not recover from a setback. While the plants are small they should be protected from the hot sun. Though it takes considerable work to raise a crop of egg plant the fine bulbs which may be made into many appetizing dishes are worth the effort.

Improved Large Purple. This produces a vigorous plant bearing large bulbs and is very early. Price, packet 10e, ounce 50c, postpaid.

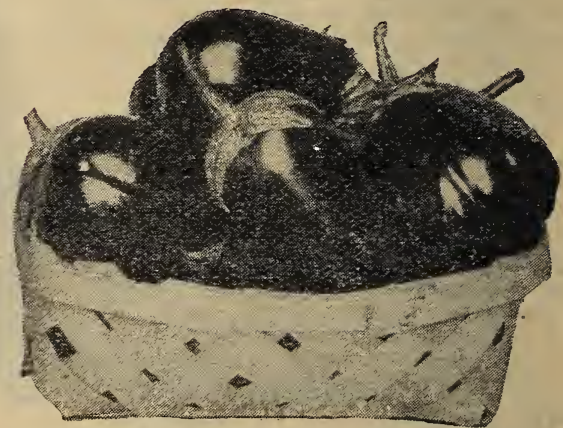

Improved Large Purple Egg Plant. 


\section{LETTUCE}

One ounce for 200 feet of row.

Plant in rows a foot apart and thin as the plants grow; the leaves may be used for table when quite small but retain their flavor until the seed stems are formed. As lettuce will stand, a number of frosts it may be planted very early in the spring. If il number of plantings are made a week or more apart, or early late and medium varietiss are planted at one time a supply of lettuce may be had through the entire growing suason. Loose leaf lettuce is ready for use as soon as the leaves are formed. while head lettuce is best when the head is fully developed.

Grand Rapids. A loose leaf sort that does best under glass, but produces a very fine crop when planted in the open. Has a large bright green leaf crimped around the edges and remains tender for a long time. Price, packet 5c, ounce 10e, 1/.1 pound 30c, pound $\$ 1.00$, postpaid.

Black Seeded Simpson. Produces a very thin leaf. This lettuce will stand handling better than most sorts. Price, packpt 5e, ounce 10e, $1 / 4$ pound $30 \mathrm{c}$, pound $\$ 1.00$. postpaid.

Early Curled Silesia. An exceptionally early variety which has a large, tender. light green leaf. This is the first thing of the spring planting to be ready for use from the garden. Price, packet 5e ounce 10c, $1 / 4$ pound $30 c$, pound $\$ 1.00$, postpaid.

Prizehead. Grows in a large, loose cluster of finely ribbed leaves varying from brown to light green in color. T is kind produces more lettuce from a give? number of plants than any other leaf lettuce. It is much used by market gardeners. Price, packet 5c, ounce 10c, $1 / 4$ pound 30e, pound $\$ 1.00$, postpaid.

Early Curled Simpson. A decided'y crisp variety. Color, very light greer never spotted or brown in any part. Quality excellent; sweet in flavor. Pric: packet 5e, ounce $10 \mathrm{c}$, $1 / 4$ pound $30 \mathrm{c}$, poun? $\$ 1.00$, postpaid.

The foregoing are the leading varieties of leaf lettuce. We offer here the thre leading varieties of head lettuce which have stood the tests in this country.
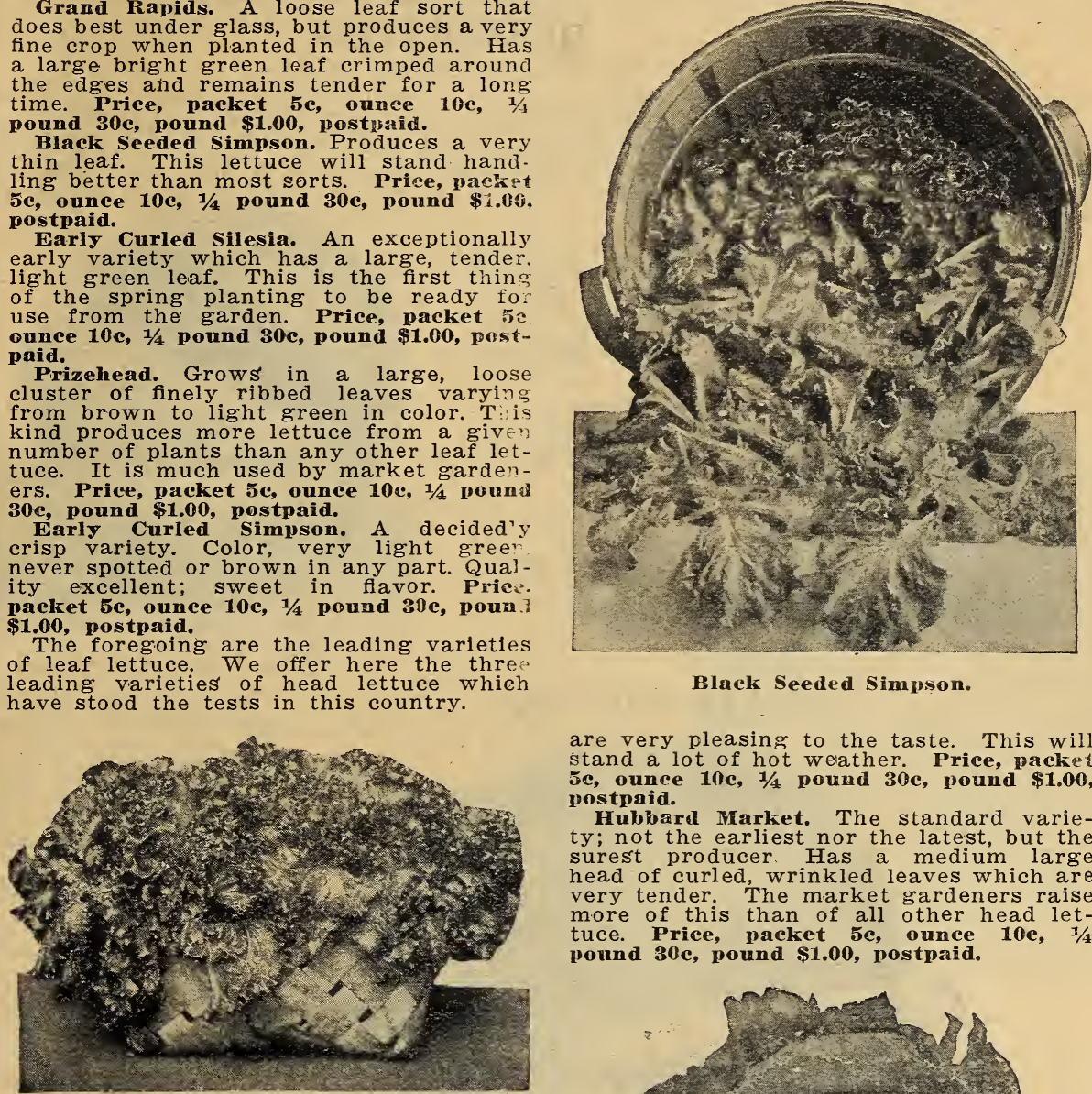

Black Seeded Simpson.

are very pleasing to the taste. This will stand a lot of hot weather. Price, packes se, ounce 10e, $1 / 4$ pound $30 c$, pound $\$ 1.00$, postpaid.

Hubbard Market. The standard variety; not the earliest nor the latest, but the surest producer. Has a medium large head of curled, wrinkled leaves which are very tender. The market gardeners raise more of this than of all other head lettuce. Price, packet 5e, ounce 10c, 1/4 pound 30c, pound $\$ 1.00$, postpaid.

\section{Hanson Head Lettuce.}

Hanson Head. One of the most valuable of the crisp heading sorts. It is $v$ hardy and will stand more unfavorable weather than other head lettuce. Has a large head of crisp leaves, green at th? outside and blanching towards the cer ter. The table quality is excellent and $i$ remains in splendid condition for use long time after maturity. Price, packest 5e, ounce 10e, $1 / 4$ pound $30 c$, pound $\$ 1.00$, postpaid.

Early White Cabbage. The earliest head lettuce. A large, firm head of leaves which resemble cabbage in texture, but

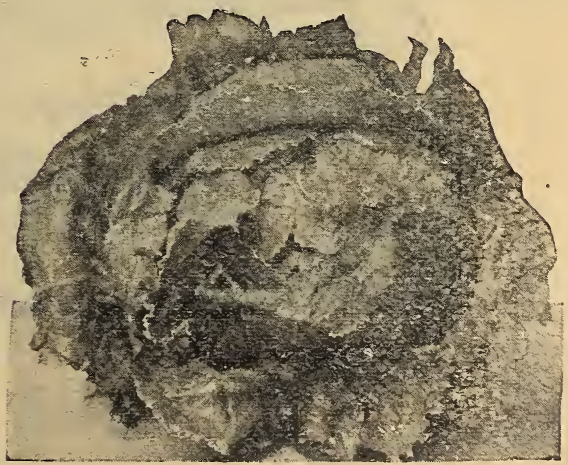

Grand Rapids. 


\section{LEEK}

One ounce of seed for 200 feet of row.

This is a plant much used in Europe, but little known in this country. The blanched stems and roots are used to flavor soup and gravy and are cooked with meat. The flavor is something like that of an onion, but the leek has a peculiar tang not found in the onion and this is much prized by people accustomed to it. Plant the seed in a bed early in spring and transplant 8 inches apart e way when plants are 6 inches tall. $\mathrm{Cc}$ all but the center leaves when transple ing and cultivate as celery is handled

Large American Flag. Has a qu growth producing long stems of large and very mild flavor. Price, packet ounce 15c, postpaid.

\section{MUSKMELONS}

One ounce of seed for 100 hills.

Melons require a much richer soil than the common garden products and should $\mathrm{h}$ more water than usually falls in this state, but where care is taken to provid,e suita soil and water is put upon the hills when a dry spell comes, the crop from a few 1 will furnish a rich reward for the extra labor

Plant 12 or 15 seeds in hills 6 feet apart each way and thin to 4 best nlants af they start. Cultivation will preserve the moisture and keep the weeds out of the vil

Extra Early Hackensack. One of the earliest and hardiest kinds. Produces large fruit slightly flattened. Skin is green tinged with yellow; the meat is green and coarse, but very sweet. Price, packet 5c, ounce 10c, $1 / 4$ pound 30c, postpaid.

Improved Early Green Nutmeg. Not quite so large as the Hackensack and the meat is more solid, but a very desirable melon. Price, packet 5c, ounce 10c, 1/4 pound 30c, postpaid.

osage. An oval-shaped fruit, slightly ribbed. Has a green mottled skin and fine texture salmon colored flesh. Has a very small cavity and will keep longer than the larger sorts. Price, packet $5:$, ounce 10c, $1 / 4$ pound $30 e$, postpaid.

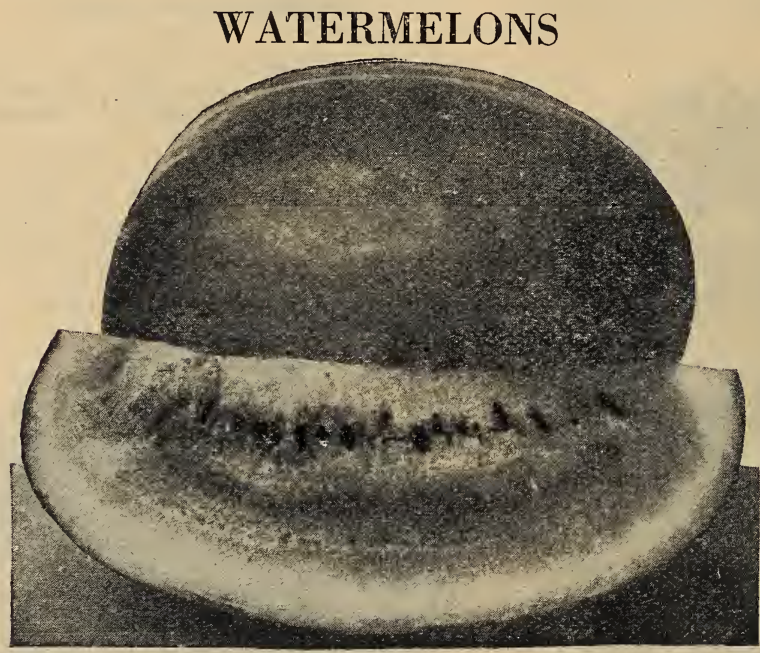

Cole's Extra Early.

\section{CITRONS}

These are unsurpassed for pickles and should be grown like melons.

Red seed. Globe shaped and look like

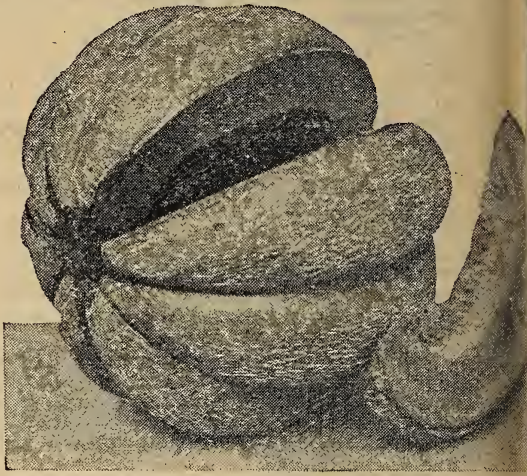

Extra Early Hackensack.

Watermelons require $t$ same treatment as muskm ons and what is said rega ing muskmelons will apply watermelons. We offer varieties of watermelon $t$ are sure to bring a satisf tory crop if the directions followed.

Cole's Extra Early. T melon has been particula bred to the northern clim and will produce a beaut crop of medium-sized fru nearly round, with a thin s: and deep red meat that melt in your mouth when ri The fact that this melon $v$ not stand shipping on accol of its thin skin is the o reason that shippers do raise them exclusively. Pri packet, 5e, ounce 10e, $1 / 4$ por z5e, postpaid.

Pinny's Extra Ea r 1 y. strain of the oblong me which has been adapted to Northwest by careful select and breeding. Has a mott skin. white seeds and deliciı meat. Price, packet 5e, ou: 10e, $1 / 4$ pound $25 e$, postpaid. 


\section{OKRA, Also called GUMBO}

This should be handled like tomatoes and the pods picked soon as they become firm. The pods may be used green or dried and kept for many months before

The young seed pods are used for fla- voring soups, stews and pickles. negro cooks of the South claim that ing equals gumbo soup.

Perkin's Mammoth. Long Pod. Is earliest strain and grows about 3 high and produces a large crop of 1 heavy pods of best quality. Price, pac 5e, ounce 15c, postpaid.

\section{ONIONS}

One ounce of seed for 200 feet of row. Five pounds per acre.

The onion can be raised to good advantage upon almost any kind of soil and the hurt them and they may be planted work done to produce it. Frost in spring does in rows 16 inches apart and thinned early in the spring as the ground can be wor crop is to be matured, as and thinned to four inches apart as the plants grow. If down. Rolling a barrel over the the bulbs commence to form the tops should be brol

Yellow Globe Danvers. A standard yellow, globe shaped bulb with a very solid body which has the sharp taste much desired by many onion users. This is heavy cropper and an excellent keeper. Price, packet 5c, ounce $25 c$, $1 / 4$ pound 85 . $1 / 2$ pound $\$ 1.60$, pound $\$ 3.00$, postpaid.

Red Weathersfield. The best known of the red onions. Produces a large, heavy bulb rather flattened; red on the outside and shading to sparkling white in the center. Not the earliest, but a very sure yielder and the crop will keep until the next year's crop is ready if properly stored. Price, packet 5e, ounce 25c, $1 / 4$ pound $85 e, 1 / 2$ pound $\$ 1.60$, pound $\$ 3.00$,
postpaid.

Prizetaker. An improved strain of $\mathrm{Yel}$ low Globe. Produces a larger bulb which matures earlier in the season and is not quite so strong. This is a good keeper. Price, packet 5e, ounce 25e, $1 / 4$ pound 90c, $1 / 2$ pound $\$ 1.70$, pound $\$ 3.25$, postpaid.

Yellow Flat Danvers. A flat bulb which matures about as the Yellow Globe, but is milder. Price, packet sc, ounce 25 , $1 / 4$ pound $85 e, 1 / 2$ pound $\$ 1.60$, pound $\$ 3.00$, postpaid.
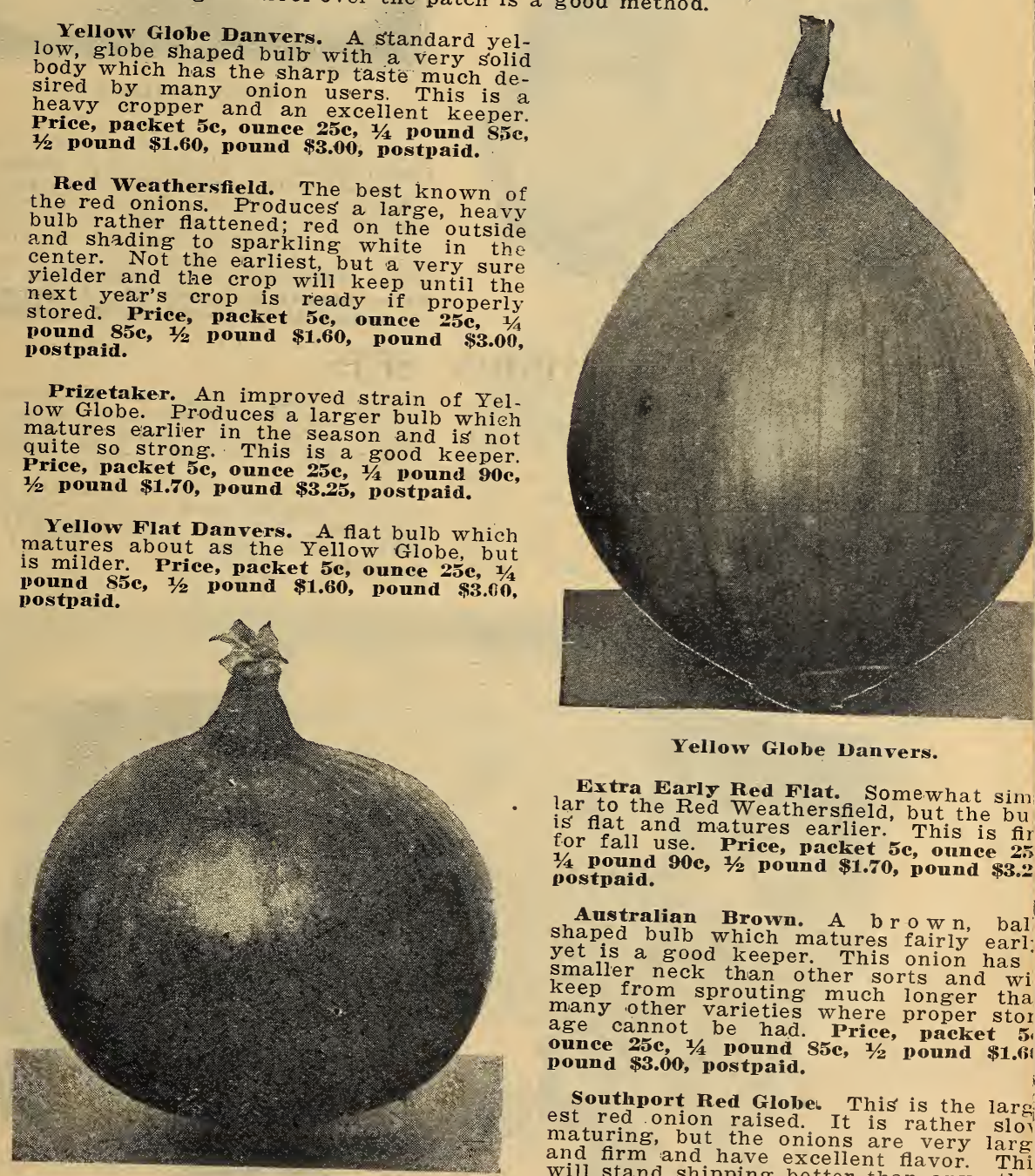

Yellow Globe Danvers.

Extra Early Red Flat. Somewhat sim lar to the Red Weathersfield, but the bu is flat and matures earlier. This is fir for fall use. Price, packet 5c, onnce 2. $1 / 4$ pound 90e, $1 / 2$ pound $\$ 1.70$, pound $\$ 3.2$ postpaid.

Australian Brown. A b r o w n, bal shaped bulb which matures fairly earl yet is a good keeper. This onion has smaller neck than other sorts and wi keep from sprouting much longer tha many other varieties where proper stor age cannot be had. Price, packet 5. ounce $25 c, 1 / 4$ pound S5e, $1 / 2$ pound $\$ 1.6 !$ pound \$3.00, postpaid.

Southport Red Globe. This is the larg est red onion raised. It is rather sloi maturing, but the onions are very larg and firm and have excellent flavor will stand shipping better thi red onion. Price, packet 5e, ounce $25 c$, 1 , pound 85e, $1 / 2$ pound $\$ 1.60$, pound $\$ 3.04$ postpaid. 


\section{ONIONS-Continued}

Mammoth Silverskin. If you want the largest onion any seed will produce, plant this variety. A monster white bulb composed of crisp white meat in heavy layers; very mild flavored. This onion is particularly fine for slicing. Price, packet 5 , ounce $25 c, 1 / 4$ pound 90e, $1 / 2$ pound $\$ 1.75$; pound $\$ 3.25$, postpaid.

White Barlatta. A decided novelty. When the bulbs are fully matured they are small, perfectly formed globes. They have sparkling white flesh and the deli-

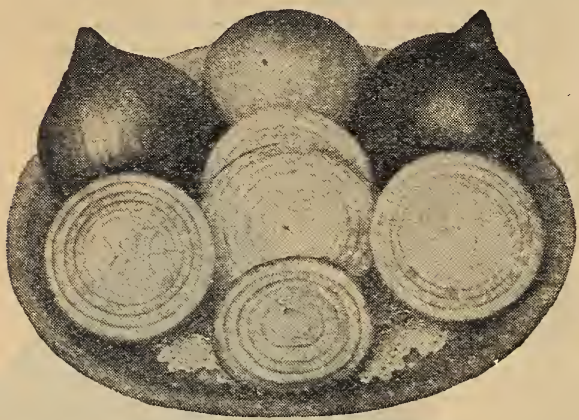

Southport Red Giobe.

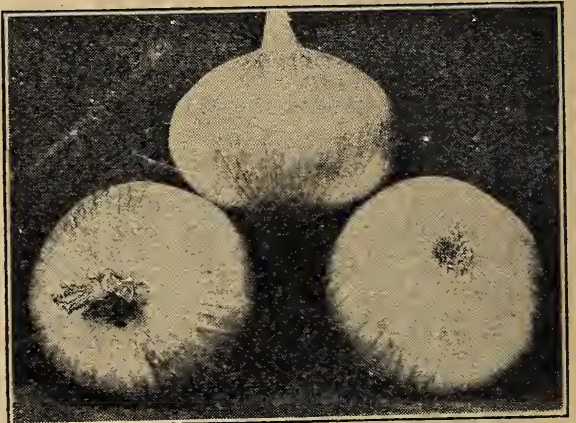

White Barlatta.

cate flavor which makes perfect pickles. Price, packet 5e, ounce 25e, $1 / 4$ pound $85 c$, $1 / 2$ pound $\$ 1.60$, pound $\$ 3.00$, postpaid.

White Picking onion. Extensively used for pickling or sets. Plant thicker than for ordinary crop and a yield of uniform medium-sized bulbs with a clear white skin and mild flavor will result. Price, packet 5e, ounce 25c, $1 / 4$ pound $85 c$, $1 / 2$ pound $\$ 1.60$, pound $\$ 3.00$, postpaid.

\section{ONION SETS}

Young onions will be fit to eat earlier if raised from sets than from seed and the set onions may be left in the ground and will mature earlier than the seed onions. We do not ship sets until the danger of frost is over in the spring. The set crop for 1919 was very short; we had a contract for a good supply, but will not get all of our order. For this reason we would advise that you order sets early

that you may be sure of obtaining what you want. From present indications there will be no sets upon the open market next season and we will fill orders in the order received.

Prices, red bottom sets, quart 25c, $1 / 4$ bushel $\$ 1.50$, postpaid; yellow bottom sets. quart 25c, $1 / 4$ bushel $\$ 1.50$, postpaid; white bottom sets, quart 30c, $1 / 4$ bushel $\$ 2.00$. postpaid.

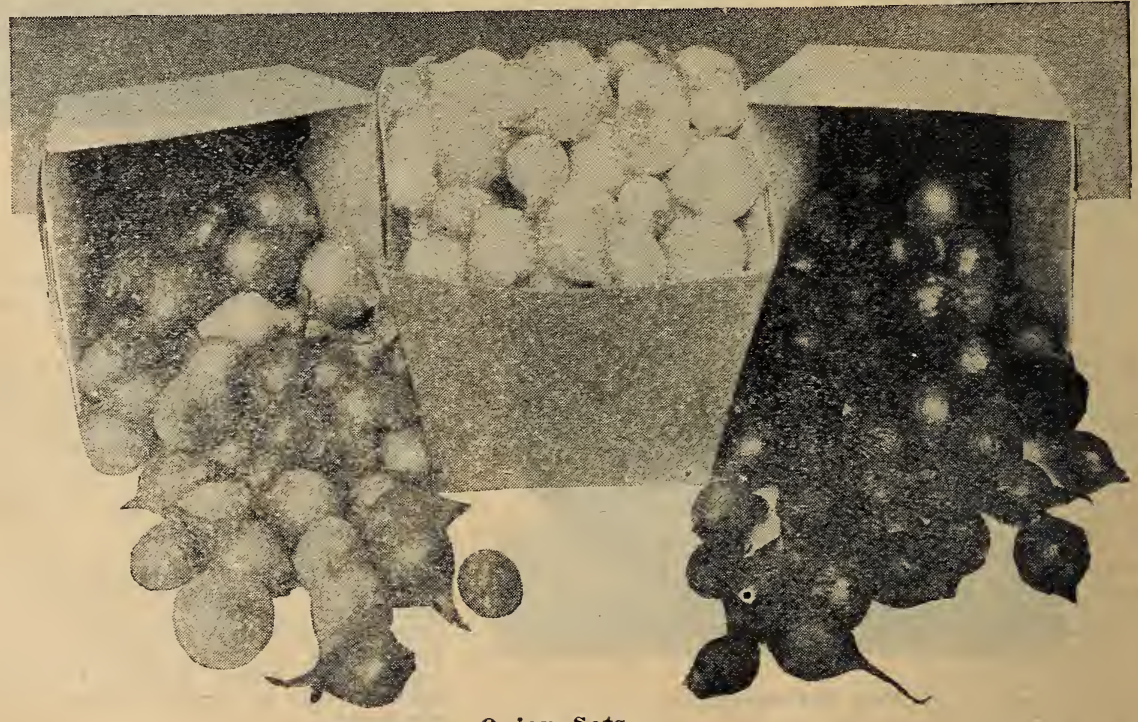

Onion Sets. 


\section{PEAS}

Very few farmers in this country take the precautions to have pure strain seed or take the time to grow and care for a crop of beans or peas so that they will have firstclass seed. Because of this fact, the bulk of the northwestern dealers obtain their. stocks from eastern and southern growers. The past season, the seed crops of the growis high.

We are particularly fortunate in having a large amount of home-grown peas and beans which were raised, some under contract for us and the rest by people to whom we furnished seed which we know was pure and the crop properly cared for. This gives us a very fine stock which we know is of the right strains and most important is aceliported seed. But "first satisfactory results which might not be obtained from imwhich is not correct the first first served" and, while we will not put out anything your order come early.

One pound of seed for 60 feet of row. One hundred and twenty pounds per acre.

Sow in a light sandy soil for early peas. If a number of plantings are made 2 weeks apart or early, medium, and late peas are planted at the same time th season for green peas may be made th last from about July 1st until frost. The pods should be picked soon as the peas are well formed and the vines will bear fresh pods. But when the pods commence to ripen the vines stop bearing. Ripe peas are fine for soup and will keep a long time.

\section{WRINKLED VARIETIES}

Laxtonian. A medium early dwarf vine which grows about 12 inches high and needs no supports. The pods are very large, often having 10 peas in a single pod. The extra heavy vines make this a favorite for home gardens, as the vines will continue to bear for a long time if the pods are picked regularly. Price, large packet $10 \mathrm{c}$, $1 / 2$ pound $25 c$, pound $45 c$, 5 pounds $\$ 2.00$, postpaid.

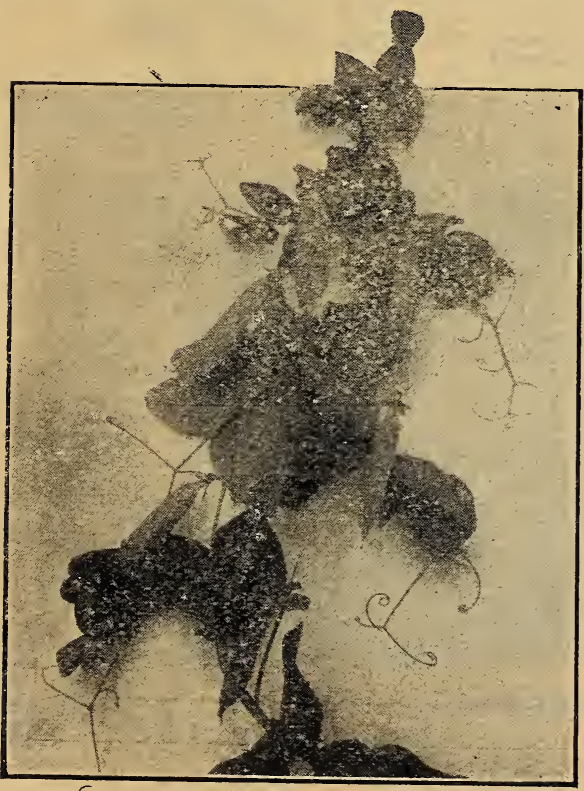

American Wonder.

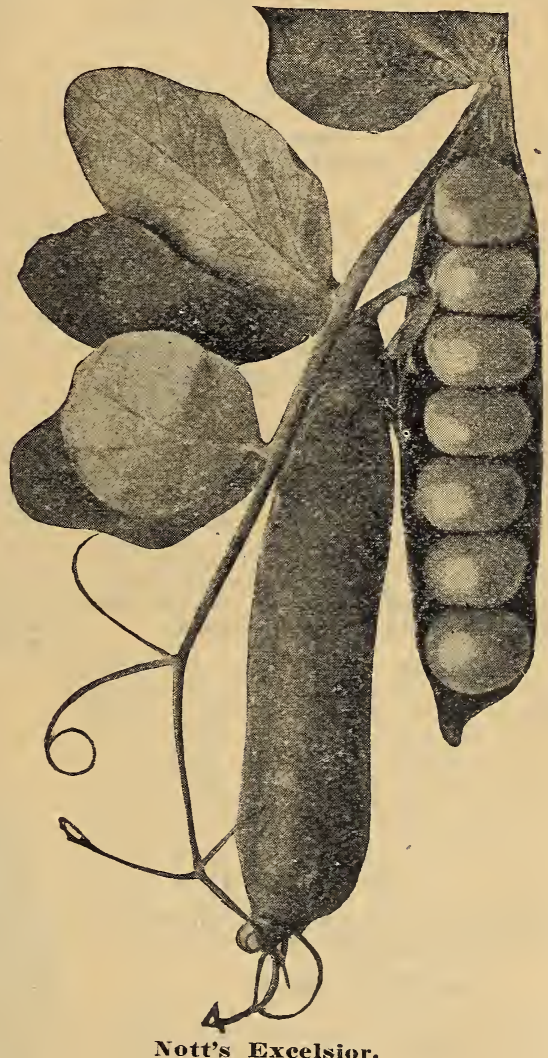

American Wonder. Vigorous, productive vines with a luxuriant growth of foliage, having leaves upon but one side of the stalk. This makes picking much easier and as the vines grow but 10 to 12 inches high and are filled with straight, heavy pods containing many delicious peas, this is well worthy of a place in any garden. Price, large packet 10c, $1 / 2$ pound 25e, pound 40c, 5 pounds $\$ 1.90$, postpaid. 


\section{PEAS-Continued}

Prosperity. So called by the gardener ho claimed that it brought prosperity to m. A very early bush pea carrying a avy, even maturing crop of long pods at have exceptionally large peas. The ct that the pods all mature at the same ne allows the gardener to clean the nes at a single picking, and save time id labor in marketing the crop. Price, rge packet 10c, $1 / 2$ pound $25 c$, pound 40 s, pounds $\$ 1.90$, postpaid.

MeLean's Little Gem. Produces a crop peas very rich and buttery. The suriority of the crop has won it many ' $m$ friends. Price, large packet 1fe, $1 / 2$ und 25e, pound 40e, 5 pounds $\$ 1.90$, postlid.

Premium Gem. Somewhat similar to cLean's Little Gem, but is a little slowgrowth and brings a heavier crop of ost delicious peas. Price, large pack"t ie, $1 / 2$ pound $25 c$, pound $40 \mathrm{~s}$, 5 pounds .90 , postpaid.

Bliss Everbearing. Vines stout, about 12 feet high, bearing many broad pods. the pods are picked as they fill, new anches will be thrown out and another op of pods will be produced. The peas - e sweet, cook tender and this is consid'ed the best for the garden by many of ir customers. Price, large packet 10e, $1 / 2$ ound 25c, pound $40 \mathrm{c}$, 5 pounds $\$ 1.90$, ostpaid.

Ch a mpio n of England. All of our merican peas are strains of European igin, most of them in England, and this as been declared the best variety the nglish growers ever produced. A heavy opper, large, rather late maturing, but 0 sweeter pea is grown upon any vine. rice, large packet $10 c, 1 / 2$ pound $25 c$, ound 45c, 5 pounds $\$ 2.00$, postpaid.

Nott's Excelsior. The pea for the orthwest. The earliest of the wrinkled eas. Vines grow 8 to 10 inches high, ut are full of well-developed pods filled ith green peas so delicious that they ielt in your mouth. We have seen these eas grown and matured for several years ere at Valley City and each year they nprove in earliness and vigor. You will lake a mistake if you do not have a libral supply of these home-grown seeds 1 your order for the next garden. Price, lrge packet 10c, 1/2 pound $25 c$, pound 45e, pounds $\$ 2.00$, postpaid.

\section{SMOOTH PEAS}

The round peas do not grow as large as te wrinkled kinds, but are usually earer and some people claim that they are ner flavored.

Alaska. Ready for table in 40 days is ot uncommon for this pea. A strong ush growing about 2 feet high bearing luxuriant crop of most delicious peas. 'rice, large packet 10e, $1 / 2$ pound 25e, ound $40 \mathrm{e}, 5$ pounds $\$ 1.90$, postpaid.

Extra Early. Grows very rapidly and latures a fair crop of excellent peas very venly. This is the market gardener's hoice for early peas. Price, large packet 0e, $1 / 2$ pound $25 \mathrm{c}$, pound $40 \mathrm{c}, 5$ pounds 1.90 , postpaid.

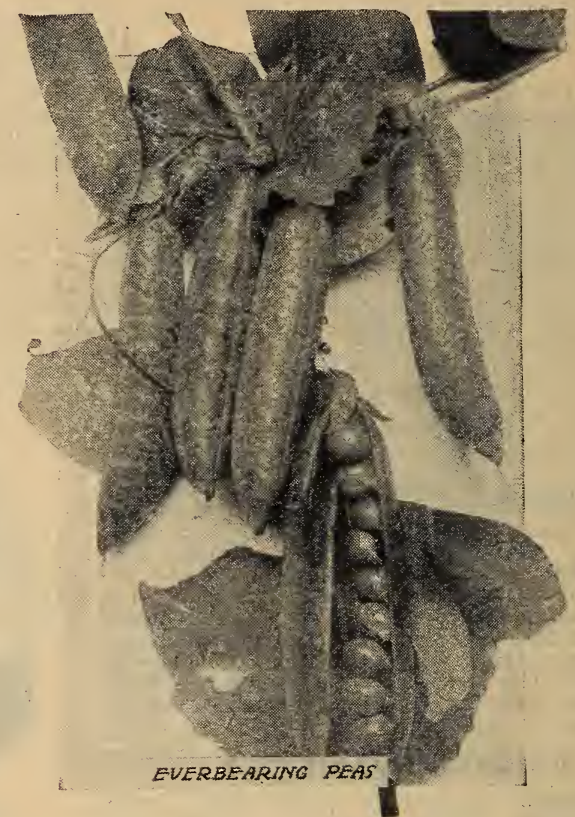

DWARF GRAY SUGAR PEA

This is something different from the other peas, as both the pods and young peas are cooked and eaten. Will be ready for the table ahead of string. beans and many people consider the flavor superi.or to beans. Try a few of these this year and you will always have them in the garden other years. Price, large packet 10c, $1 / 2$ pound $25 e$, pound $45 e, 5$ pounds $\$ 2.60$, postpaid.

\section{Field Peas}

These will grow and mature any place in the Northwest and the crop is as good feed for hogs, cattle or horses as can be grown. Back east, upon land which is run down too badly to raise oats or barley, beans and peas are the main crops; the beans for market and the peas for feed. A few acres of peas will finish a bunch of hogs as well as any grain. The crop may be threshed and fed or "hogged off."

We must get away from the grain idea and no better start can be made in the right direction than by having a bunch of hogs to finish upon a field of peas. The pork will be higher priced and the land upon which the peas were raised will produce a better crop the next year.

Two bushels per acre is the correct amount of seed. Wle offer home-grown acclimated CANADIAN FIELD PEAS at $25 \mathrm{c}$ per pound postpaid or $\$ 5.00$ per bushel by freight or express. Sacks extra, 65c each.

Northern Seed Co., Valley City, N. D.

I have planted your seeds four years and am more than pleased with the results. Osage, Minn. Mrs. J. J. Breuer. 


\section{PARSLEY}

One ounce of seed for 200 feet of row.

Used as flavoring for soups and stews. The leaves are used green or may. be dried and powdered and used that way.

Plant in rows about a foot apart and thin to 4 inches between plants. It germinates very slowly and a few radish seed planted with the parsley will mark the rows for cultivation and the radishes will be out of the way before the parsley reaches much size.

Moss Curled. Produces a rich, dark green growth which from a distance looks like moss. If the leaves commence to turn brown, cut the plant back and a heavier growth of green will come. Repeated cuttings will make the growth thicker. Price, packet 5c, ounce 10e, $1 / 4$ pound 30e, postpaid.

\section{PARSNIP}

This is one vegetable which will grow with little care and may be used in the fall or left in the ground and used the next spring. The flavor is improved by a frost and many people claim that nothing which grows from the ground equals a dish of well-prepared parsnips. They should be planted and handled as carrots are handled.

Hollow Crown or Gurnsey. This is the best of the strains offered to the trade. Has a long, smooth, tapering root which grows well under the ground and does grows well under the ground and growing sorts. Price, packet 5e, ounce 10e, 1/4 pound 25e, $1 / 2$ pound $45 e$, pound $90 c$, postpaid.

Northern Seed Co., Valley City, N. D.

Dear Sir: I am thankful that I got the seed. I know that your seeds are good because the seeds we got last year were very good. I am sending you the names of five of my friends for catalogs.

Gilluct Kosen.

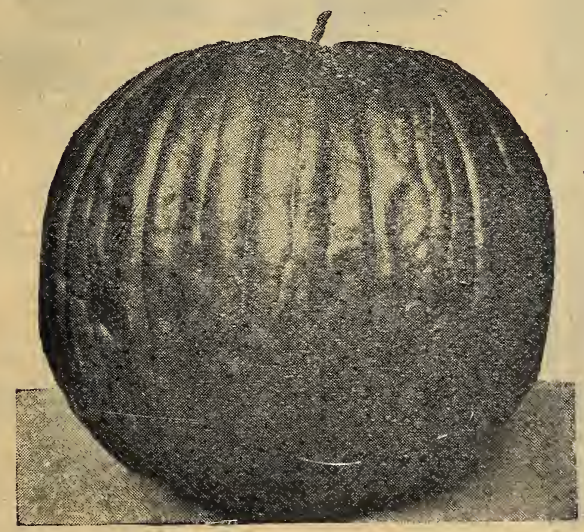

Connecticut Field.

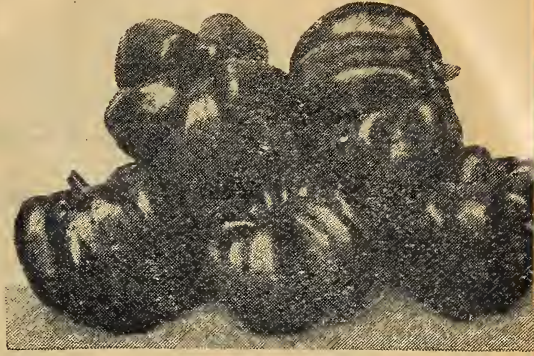

Bell Peppers.

\section{PEPPERS}

One ounce of seed for 1,500 plants.

Peppers grow too slowly to be star out of doors and mature in an ordin season. They should be started in house or under glass early in the spr and set out when danger of frost is or Have plants about 30 inches apart e way.

Bell or Bull Nose. Produces a la fruit shaped like a bell, very desira for stuffing or for mixed pickles. Pr packet 10e, ounce 50e, postpaid.

Long Red Cayenne. A medium e sort having slender twisted fruit abol inches long. Deep green while young, turns scarlet as it ripens. This is $\mathrm{m}$ desired for catsups and preserves, as flavor is excellent, while the hands coloring of the fruit adds to the att tiveness of the mixtures in which are used. Price, packet 10e, ounce postpaid.

\section{PUMPKINS}

One pound of seed for 140 hills. Fo pounds per acre.

No fall feast is complete without pu kin pie-and it is good for any other casion. Pumpkins may be grown as cumbers are handled, or planted betr the corn rows the last time corn is c vated, and will yield a bountiful with no extra work.

New England Pie (sometimes c: Sugar Pumpkin). This is a rather variety of early maturing yellow pum which has slight ribs and a very ht close-grained flesh. The best pie pi kin that can be raised. Price, packe ounce 10c, $1 / 4$ pound 35e, pound $\$ 1.25$, paid.

Connecticut Field. Raised for Many tons of excellent feed for hogs cattle can be raised from a few $p c$ of this seed. Just plant it betweer rows of the corn the last time you , vate the corn and when the corn is the pumpkins will be ready to be $h$ into the feed lot. Price, packet 5c, 10e, $x / 4$ pound $30 c$, pound $\$ 1.10$, postp! 


\section{RADISHES}

One ounce of seed for 100 feet of row.

Plant in rows about a foot apart, putting the seeds about two inches apart in the row. Radishes grow rapidly; in fact the faster growth makes the best radish. For summer to insure the best food, value.

Early Scarlet Globe. The little round radish which makes one bite of the best eating imaginable. The fact that this radish retains its bright red color a long time after being pulled makes it a favorite with market gardeners. Price packet 5c, ounce $10 \mathrm{c}, 1 / 4$ pound 30c, pound $\$ 1.00$, postpaid.

Early Scarlet Turnip. Not quite so early as the Early Scarlet Globe, but a larger radish shaped like a turnip; deep red in color and firm, close-grained meat. Price, packet 5c, ounce 10c, $1 / 4$ pound $30 c$, pound \$1.00, postpaid.

Early Scarlet Turnip White Tipped. A much-desired strain which produces a red turnip-shaped radish with white tip. This is a medium early producer and has most excellent flavor. Price, packet 5c, ounce 10c, $1 / 4$ pound $30 c$, pound $\$ 1.00$, postpaid.

Fremch Breakfast. An oblong radish, scarlet at the top and shaded to white at the tip. A very handsome appearing radish with a slightly stronger flavor than a red radish. Price, packet 5c, ounce 10e, $1 / 4$ pound 30c, pound $\$ 1.00$, postpaid.

Chartier. One of the highly developed strains produced by European gardeners. A long, tapering root, red at the top and white at the bottom. The flesh is especially crisp, as the radish will "snap" into pieces when bent in the hand. Price packet 5c, onnce $10 \mathrm{c}, 1 / 4$ pound $30 \mathrm{c}$, pound $\$ 1.00$, postpald.

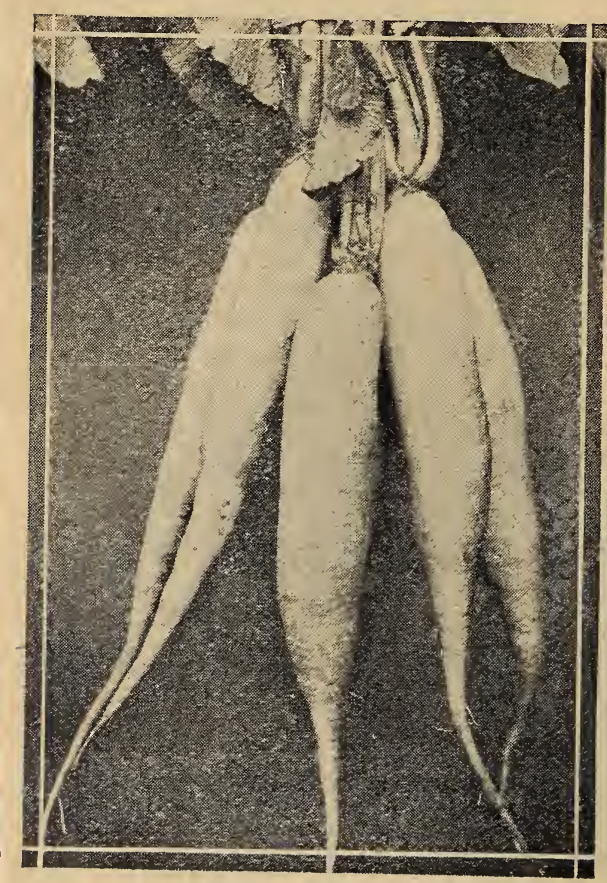

White Icicle.

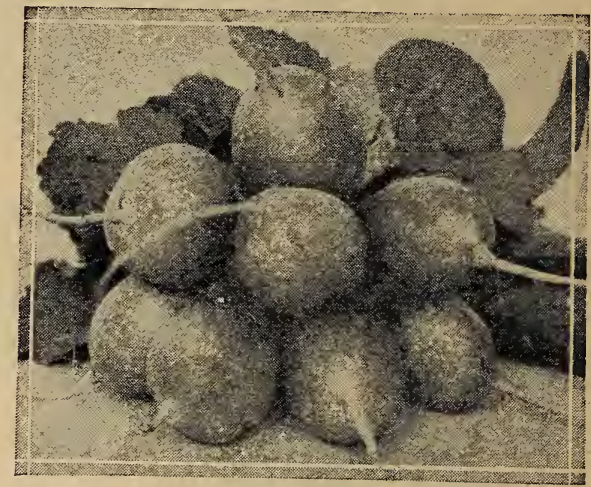

Searlet Globe.

Early White Turnip. The earliest white radish. Grows to a ball about one inch across and, while crisp and juicy, nd. not the "tang" of the red radishes. Price. packet 5e, ounce 10c, $1 / 4$ pound 30c, pound $\$ 1.00$ postpaid'

White Olive. A slower maturing radish than White Turnip but a heavier radish, pure white throughout. Price, packet 5c, ounce 10c, $1 / 4$ pound 30c, pound $\$ 1.00$, postpaid.

White Icicle. A long tapering white radish. Quite early and very finely flavored. Price, packet 5c, ounce 10c, $1 / 4$ pound 30c, pound $\$ 1.00$, postpaid.

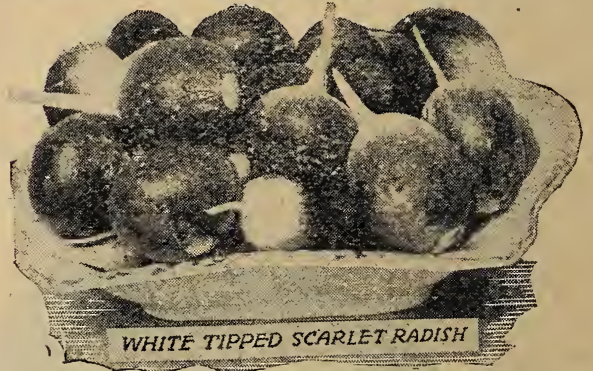

White Strasburg. A slow growing, delicious white radish. It may be eaten quite small but retains its delicate flavor until two inches in diameter. Price, packet 5e, ounce 10c, $1 / 4$ pound $30 \mathrm{c}$, pound $\$ 1.00$, postpaid.

Black Spanish. This is a radish which may be kept all winter and has "the real radish taste" any time. Plart and care for them like carrots and have radishes for Christmas dinner. Price, packet 5c, ounce 10c, $1 / 4$ pound 35e, pound $\$ 1.10$, postpaid.

China Rose. A white winter radish which grows to a good size-1 $1 / 2$ or 2 inches across at the top and slightiy larger at the bottom. It may be kept as the Black Spanish and makes a.welcome variation for winter diet. Price, packet 5c. ounce $10 \mathrm{c}, 1 / 4$. pound $35 c$, pound $\$ 1.10$, postpaid. 


\section{SALSIFY}

One ounce of seed for 100 feet of row.

This is sometimes called "Vegetable -Oyster."

It is a little known vegetable which should be grown and used, especially by the people of this country who live upon a diet of meat, bread and, potatoes for the greater part of the year. Salsify may be grown in any garden with no more care than potatoes and the roots, tasting much like an oyster may be prepared for the table in many pleasing ways. Sow early in spring in rows 20 inches apart and thin to four or five inches between plants. Pack the mature roots in sand and keep in a cool place and they will be ready for use at any time thru the winter.

Mammoth Sandwich Island. This is the variety best adapted to our conditions. It produces a large tapering root with few stringers. Price, Packet 5e, ounce 25e, postpaid.

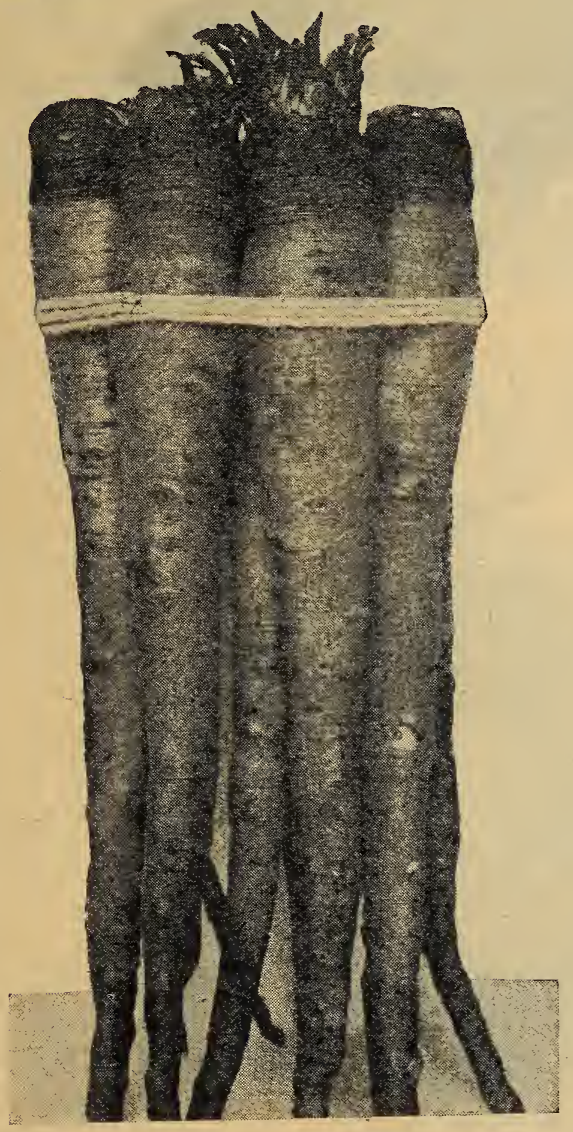

Mammoth Sandwich Island Salsify.

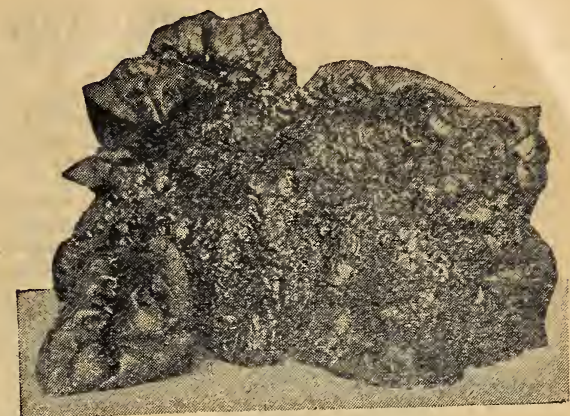

Spinach.

\section{SPINACH}

One ounce of seed for 100 feet of row.

The highest praise any "green" is ever given is to say that it is "like spinach." This shows that the knowing ones want spinach. It is easily grown; plant early in spring in rows 20 inches apart and thin to four inches between plants. When a plant is cut off to be used a new crop of leaves start. Price, packet 5c, ounce 10c, $1 / 4$ pound $30 c$, pound $\$ 1.00$, postpaid.

\section{SUNFLOWER}

2 ounces to 100 feet of row -10 pounds to the acre.

Culture. Plant in rows three feet apart and thin to one plant every six inches. Bury the seed about one inch firming the soil well. Frequent cultivation. will give better results.

Iammoth Russian. Stalks grow eight to fourteen feet high and the heads have a diameter of 12 to 22 inches. Sunflowers a be planted and handled the same as can be planted and crop is matured the seed will make. one of the best poultry feeds obtainable. The yield has been known to be a hundred bushels per acre. It will to be a hundred bushels per acre. give the fowls a bright lustrous plummage, it keeps them the eggs hatch more condition, it maks and will do more to keep a flock laying than any other one food that can be fed. The dry heads may be that can be fo, can reach them or the seed flailed or threshed out. Every poultry raiser should grow at least a small patch raiser should grow the chickens. Price, ounce 10e, pound 30e, postpaid. 10 pounds by freight or express at purchasers expense $\$ 1.50$.

Northern Seed Co., Valley City, N. D.

Please send me a new catalog for this spring. I ordered seed from you last year and everything was O. K., so I want a catalog as soon as possible. Have you some kind of seed they call Wonder Berries? I have seen them out here but do not seem to be able to get the seed. Phon, Mont. 


\section{SQUASH}

One ounce for 25 hills.

apare the ground as for cucumbers and plant the summer kind in hills four r kinds have larger growth of foliage than feet apart; the reason being that the rinter squash be careful to not bruise than the summer varieties. When gathering. keep all winter. The summer varieties and store in a cool dry place and they reep any length of time. iton Marrov. A medium large squash winter kind. It matures two weeks l of the Hubbard, which it resembles ape, but has a deeper yellow flesh. lavor is excellent. Price, Packet 5c, 15c, $1 / 4$ pound $40 c$, pound $\$ 1.50$, post-

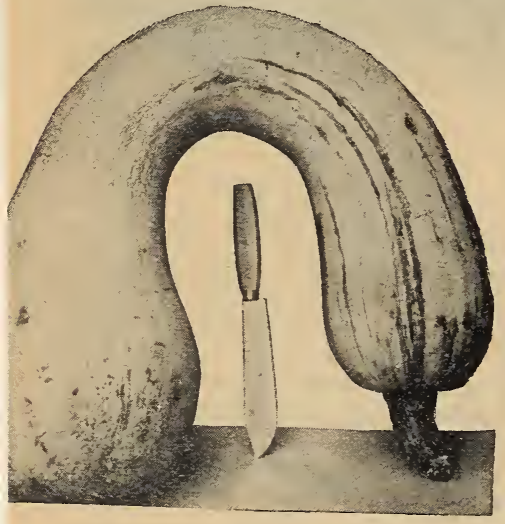

wrinkled dark green skin and light yellow pound 40c, pound und $40 c$, pound $\$ 1.50$, postpaid.

Early White Bush Scallop. The earliest excellent flat somewhat scalloped fruit of 15e, $1 / 4$ pound 40 . Price, Packet 5c, ounce Summer Crook, pound $\$ 1.50$, postpaid. squash which matures. A bright yellow for fall use. Price, pack early and is fine $1 / 1$ pound $40 c$, pound 5150 , 5e, ounce 15e, Summer So, pound $\$ 1.50$, postpaid.

Summer Squash should be used while the shell can be dented by the finger nail. The meat toughens as the shell hardens.

Summer Crookneck.

ard. The kind that was grown home." Considered, the best for storage. Has a large fruit with

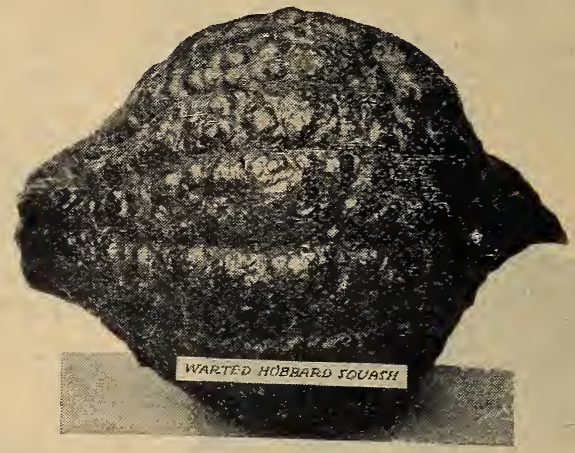

\section{TOMATOES} toes do best upon a light warm soil which is not too rich and the main thing
iecuring a good crop of tomatoes is to have the small plants keep growing
e time they start until they have reached about half their full lants get a set back, even though they start and grow full growth. If the 11 be much less than it would be from al start and grow well afterwards the $\mathrm{n}$ a hotbed, or shallow box in the ibout six weeks before time to set rs-they should be set out to set re not too cold. When plants have aves, transplant into boxes or setting plants four inches ar rden them by exposing to the out$r$ part of the time each day and tting out, protect them if a cold mes. To have best results in early as well as the largest and best $\mathrm{s}$ well to train and trim the vines. nes are eight to ten inches high, ll begin to throw out branches. te sturdiest of these and pinch off 's except the one branch and the $m$. Care must be exercised to the the fruiting branches which will $\mathrm{n}$ by the buds which which will or the branch starts. In a short two remaining branches will belually vigorous and un will bevarieties will grow four to six in a season. They should be tied inches to a stake; $2 \times 2$ inches is right size-set close to the root. II set to almost the top of the e side branches are kept trimmed such a method of training and the fruits are kept free from the ad being exposed to the sun, they

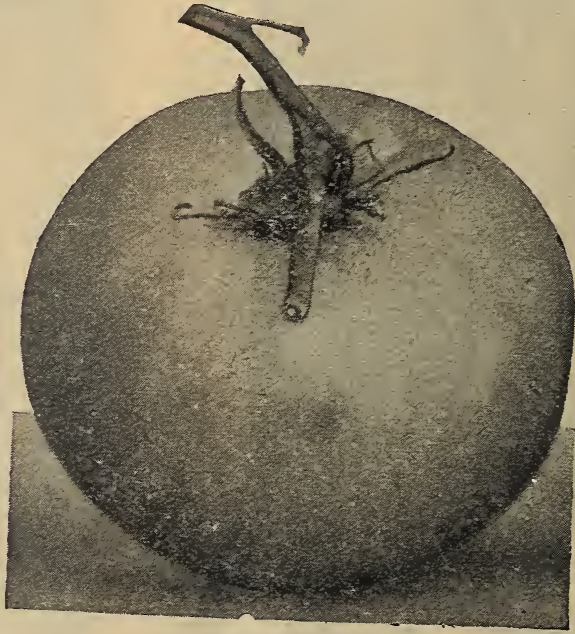

Earliana. 


\section{TOMATOES-Continued}

faster than when covered by foliage. itality of the plant, nuuch of which is leveloping foliage upon the useless aes, will all go into a larger crop of tomatoes. Ten or a dozen plants the care described here will give a crop of better tomatoes than three that number of plants as ordinarily d. And the properly handled plants ake less space in the garden and no time than trying to make the larger

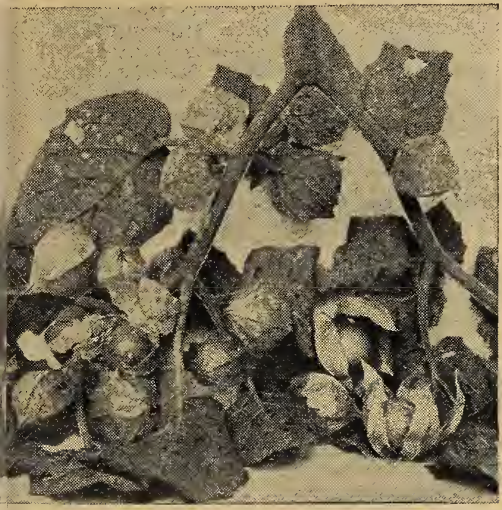

wh Tomatoes or Ground Cherries. number yield a crop under the common method.

Farliana. The king of early tomatoes. Produces a large crop of good sized, very smooth fruit, bright red outside having solid flesh which is exceptionally sweet. The tomato for the home garden. Price, Packet 5e, ounce 30c, $1 / 4$ pound. $\$ 1.00$, vound \$3.50, postpaid.

Acme. Not quite so early as the Earliana but has a somewhat larger fruit. Purple and pink outside with a very heavy skin. This is much grown by market gardeners because the fruit will stand handling better than the other sorts. Price, Packet 5c, ounce 30c, $1 / 4$ pound 90c, pound $\$ 3.40$, postpaid.

Dvarf Ghampion. Does not grow as tall as most kinds but yields an enormous crop of medium sized tomatoes which are fine for canning. Price, Packet 5c, ounce 40e, $1 / 4$ pound $\$ 1.25$, pound $\$ 4.50$, postpaid.

Chalk's Early Jewel. An old favorite which stands more abuse than the other sorts. A middle sized deep red, luscious fruit. The vines continue to bear for a great length of time. Price, Packet Бc ounce 25e, postpaid.

Yellow Cherry. Fruits are light yellow, about one-half inch in diameter and are borne in small clusters. Begins to bear early and continues until frost. Price Packet 5c. ounce 10c, pnstpgid

Grotind oz Husk Cherries. Fine Iv naking pres and dr icious for preserver The vines cover the sround $2 d_{1}$ yie abundantly. "she fruil is enc...ed in loose husk. Frice, Packet 5c, ounce 40 postpaid.

\section{TURNIPS and RUTABAGAS}

One ounce of seed for 200 feet of row. Three pounds per acre. early use. sow soon as the ground, can be worked in the spring. For main crop, after the middle of June. Beside being excellent for the table, these roots make ration for stock during the winter when all dry food is used. A mess of sliced in addition to their high food value, seem to act as a tonic for stock and a regular $f$ roots will greatly increase the flow of milk from cows. Plant them in rows et apart and thin to one plant each six inches.

le Top Strap Leaf Turnip. The main urnip. Matures in eight weeks. The ; red and purple above ground and beneath the surface. The flesh is nd retains its fine flavor for a long then stored for winter. Price, Packet nce 10c, $1 / 4$ pound $30 \mathrm{c}$, pound $\$ 1.00$, id.

te Egg Turnip. This is much planted arly turnips. The roots are egg 1 and white. They may be used small, often being ready in five from planting. Does not grow as as the Purple Top, and, has a milder Price, Packet 5c, ounce 10c, 1/4 30e, pound \$1.00, postpaid.

rican Purple Toy Rutabaga. Pro the large, yellow, oblong roots are fine to eat all winter. A touch st improves the flavor. Has a very neck and keeps well. Price, Packet nee 10c, $1 / 4$ pound 30e, pound $\$ 1.00$, iid.

arch Rutabaga. Planted mostly for use, but is a fair keeper. A flat ound with small top; crimson above ound and yellow below. Flesh firm llow. Price, Packet 5c, ounce 10c nd 30c, pound $\$ 1.00$, postpaid.

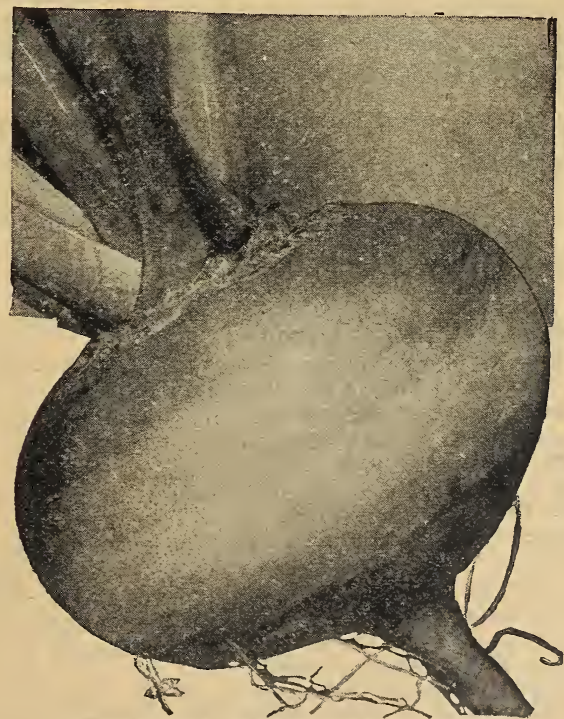

Purple Top Strap Leaf Turnias. 


\section{CAMPUS LAWN GRASS}

The campus of the State Normal School at Valley City contains one of the finest lawns in the northwest. Some years ago, we superintended the preparation of the ground and furnished the seed which was planted upon a section of the lawn. The result was so satisfactory that people of the city who were starting lawns came to us for "the same kind of grass seed that was used on the Normal grounds" in such numbers that we called the mixture "Campus Lawn Grass" and have been selling it ever since. It is composed of Kentucky Blue Grass and White Dutch Clover and we use only the purest strains of high germinating seed which we can obtain in preparing the mixture. It gives a bright green lawn, especially velvety from spring till late fall.

Starting a lawn is a very particular work. All of the soil has many hundred small seeds-weeds and wild grasses-in each square foot of surface and unless the tame grass is given a "head start" the foul seeds will come first and smother the tame grass. Have the ground well pulverized; then rake the grass seed into the surface, covering it not more than one-half irch; use plenty seed. We recommend one pound for each 350 square feet of surface. Then soak the entire surface of the lawn deeper than the seed and water it at least twice a week for six or eight weeks. The lawn grass seed will all start at one time and keep growing if sufficient water is used; this will prevent the wild seeds starting and makes the lawn evenly covered with a heavy green growth. Then do not cut it very late in the fall and you will have a lawn which will need, nothing but an occasional watering and the lawn mower for many years.

Price: 70c per pound; postpaid; 60c per pound by freight or express at purchaser's expense.

\section{VEGETABLE PLANTS}

Many people have not the time or place to grow the plants for vegetables which cannot be started out of doors. Our green house makes a specialty of furnishing strong healthy plants for transplanting into the garden at prices which are less than most people could produce the plants in their own homes for. Having large hotbeds and raising piants enough to keep a crew at work enables us to offer strong bealthy plants at very reasonable prices.

We will hold your orders until the weather is safe for shipping and advise that you set out the plants received from us soon as they arrive.

Following are the prices which include packing and postage:

CABBAGE' PLANTS-Early or late varieties, per hundred...............\$1.30 CELERY PLANTS-White Plume or Giant Pascal, per hundred...............50

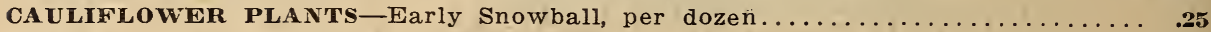

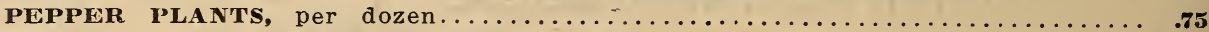

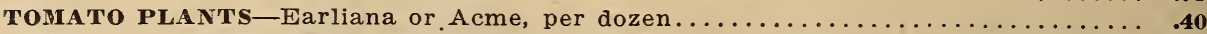

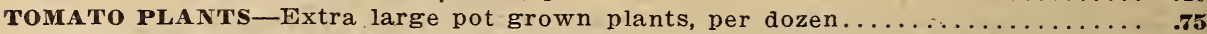

We cannot ship pot grown tomato plants by mail and the price is for plants to be shipped by express; you pay the express charges.

\section{HERBS}

Anise-Used for cordials, garnishings and flavorings. Price: Large Pkt., 10; postpaid. Balm-Leaves used for making pleasant beverages. Price: Large Pkt., 10e; postpaid. Basil Sweet-The leaves are used in flavoring soups, etc. Price: Large Pkt., 10c; postpaid.

Borage-Leaves used, for flavoring; flowers furnish bee pasture. Price: Large Pkt. $10 \mathrm{c}$ postpaid.

Caraway-Grown for the seeds which are used for flavoring. Price: Large Pkt., 10c; postpaid.

Catnip or Catmint-The leaves and young shoots used for seasoning. Price: Large

Pkt., 10c; postpaid.

Coriander-Grown for seed; used in making candy and to disguise the taste of medicines. Price: Large Pkt., 10c; postpaid.

Dill-Has an aromatic odor and pungent taste, used in the making of dill pickles. Price: Large Pkt., 10e; postpaid.

Fennel Sweet-Seeds used in confections and medicines. Young shoots used in salads, soups, etc. Price: Large Pkt., 10c; postpaid.

Horehound-Used in seasoning and cough remedies. Price: Pkt., 10c; postpaid.

Lavender-Used in the distillation of lavender water and dried to perfume linen.

Price: Pkt., 10c; postpaid. Majoram Sweet-The young shoots or the dried leaves used to flavor soups, dressings,
etc. Price: Pkt., 10c; postpaid.

Pennyroyal-For flavoring puddings, etc. Price: Pkt., 10c; postpaid.

Rosemary-Leaves used to flavor meats. Blossoms used in making toilet waters. Not large enough for use until the second, year. Price: Large Pkt., 10c; postpaid.

Sage-Much used and indispensable for flavoring. Price: Large Pkt., 10c; postpaid.

Summer Savory-The dried stems and leaves used in flavoring soups, dressings, etc.

Price: Large Pkt., 10es postpaid.

Thyme-A medicinal herb, grows about 10 inches high, used largely as seasoning or in the treatment of nervous headaches. Price: Large Pkt., 10c; postpaid. 


\section{FLOWERS}

Benjamin Franklin's saying "All work and no play makes Jack a dull boy" is truthully applied to the young folk's labor in the garden. But a bed, or number of beds of flowers become "play" to a great majority of children and the grown folks will derive much satisfaction and enjoyment from the glorious masses of rich fragrant blooms which a variety of flowers will produce from a small space. A little care in selection and cultivation will yield flowers from early spring until killing frosts in the fall Growing flowers make the garden a brighter place to work and cut flowers are fall. Growing flowers make decoration for the house or table. After all, we take nothing with us when we leave the world so that our aim should be to get as much out of life as possible, and every one will enjoy flowers around the home.

We have selected here the varieties best suited, for our trade and we know that, if given a fair chance, they will produce blooms here.

\section{Ageratum}

Blooms early and continues to bloom late in the fall; a small blue flower, very pleasins to the eye.

Imperial Dwarf Blue. Grows about eight inches tall and bears a profusion of blooms. r'rice, Packet 10, postpaid.

\section{Alyssum}

A very pretty edging for beds; grows like a tiny hedge of green dotted with varicolored fragrant blooms.

Sveet. Grows about eight inches high but spreads wide. Price, Packet 10c, postpaid.

\section{Anemone-also called Wind Flower}

A choice autumn bloom. It is at its best when the most of the others have faded.

Single Mixed. Blooms when stems are six inches long and the blooms often measure two inches across. Resembles the poppy in shape and coloring. Price, Packet 10c, postpaid.

\section{Aster}

May be planted very early, as they stand frost.

Queen of the Market. A very early flowering sort having a main stem 18 inches long which bears 10 to 15 blooms. We offer the following strains: vinite, light blue, dark blue, crimson, mixed (containing all of the above and many others) at 10e per packet, postpaid.

Crego Giant. An American development which blooms slower than the Queen of the Market, but has larger blooms which have very long petals that usually curl. We have this variety in lavender and pink. Price, packet 10c, postpaid.

\section{Bachelor's Button}

Rather tender but makes a rapid growth if planted late in the spring. Produces many colored flowers that resemble the bloom upon a wild thistle. This is called "Corn Flower" and is a well established favorite with old gardeners. Price, packet 10e, postpaid.

\section{Balsam-also called Lady Slipper} Produces many large blooms shaped somewhat like a slipper and as many colors as the rainbow. A large number of "stools" each bearing two or three blooms grow from a single seed. Will give flowers from August first until killed by frost. We offer a choice mixture containing all of the strains which mature in this climate Price, packet 10c, postpaid.

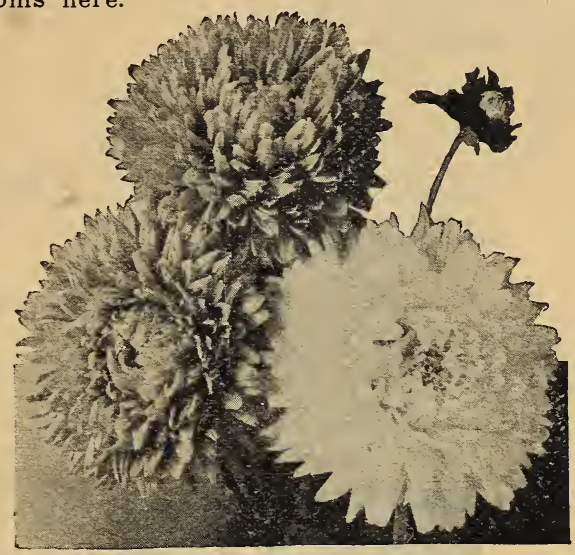

Asters.

\section{Canterbury Bells}

A large bell shaped bloom of delicate texture in many shades and colors. Price, packet $10 c$, postpaid.

\section{Castor Beans}

Make a very effective center for a flower bed, as the stems grow six feet tall and and are covered with wide foliage. I'rice, packet $10 \mathrm{c}$, postpaid.

\section{Chrysanthemum}

The "top notch" of splendor in flowers. They are grown extensively by florists for cut flowers because of their elegant appearance but can be easily grown in an ordinary garden. There are two distinct varieties, one growing from seed and the other propagated by dividing the roots of growing plants. We offer here the seed of the best summer blooming kind. Price, packet $10 \mathrm{c}$, postpaid.

\section{Candytuft}

This was a prime favorite in the gardens of 50 years ago and still has many friends. Grows 15 inches high and produces a profusion of long handsome blooms in about 10.0 days growing time. Price, packet 10e, postpaid.

\section{Cosmos}

A fall blooming bush which reaches five feet high from spring planting and is a mass of blooms from August until snow flies. Price, packet 10c, postpaid. 


\section{Cypress Vine}

Particularly effective if trained upon a light trellise. Has a profusion of star sliaped white and scarlet blossoms and its finely cut foliage is very showy. Will climb 15 feet in a single season. Price, packet 10e, postpaid.

\section{Forget-Me-Not}

Does not bloom until the second year but is much admired in permanent flower beds for its dainty blue flowers, that come early and stay late. Will not winter kill if given protection in the garden. Price, packet 10c, postpaid.

\section{Four O’clock}

A hardy plant that bears red, white and blue stripped blossoms which open in the afternoon. This was grown in American gardens before clocks were known and its name indicates its opening time. Price, packet 10e, postpaid.

\section{Heliotrope}

Much prized for the dainty fragrance of its fragile blooms. The roots should be taken up in the fall and kept from freezing, in a dry place, and set out the next spring. Price, packet 10c, postpaid.

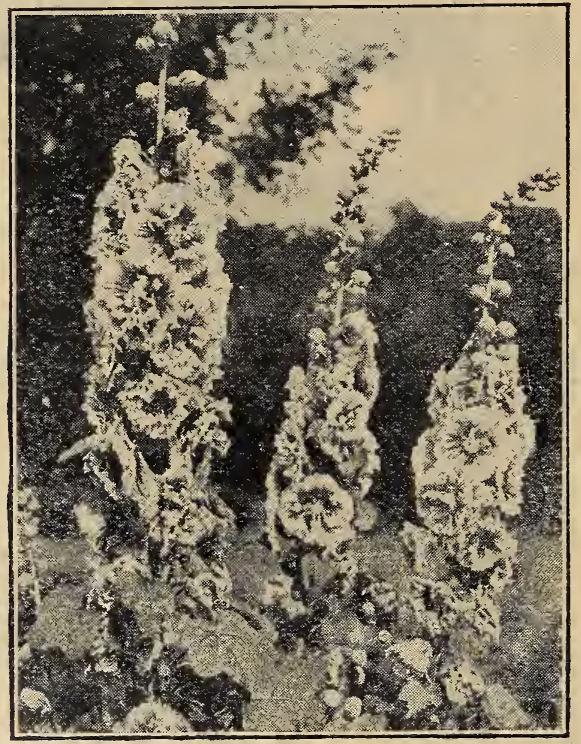

Hollyhoeks.

\section{Hollyhocks}

There are two varieties of this plant; one blooms the year it is planted and the other will winter in the garden and give blooms early and late the second year. The stems grow as high as five feet and are covered with many colored spike blossoms.
Early Flowering. Blooms the first yea - if planted in May, flowers appear in Aug ust-and bears many colored double blos soms. Price, packet 10e, postpaid.

Hardy Perennial. The best of the seeon year bloomers. Will be covered wif blooms in June and continues to bloom un til late in the fall. Price, packet 10c, post paid.

\section{Kochia}

This is called summer cypress and grown for the wonderful stand of heav foliage-often three feet high in a singl season-which it produces. It is brigh green thru the summer and turns scarle in the fall, making a handsome border o hedge. It is often used making up boquet as its delightful green sets off the beautie of flowers. Price, packet 10e, postpaid.

\section{Mignonette}

No flower garden is complete withou this dainty shaped blossom containins many colored petals. A few blossoms pro duce a pleasing odor which permeates th. entire lot upon which they are planted We have a particularly hardy strain whicl produces large blooms. Price, packet I0c postpaid.

\section{Marigold}

This is rather delicate and should b. started indoors and handled as tomati plants. But the elegant yellow and orangt blooms will repay you for the extra worl required to produce them.

Dwarf Freneh. A low bush whicl flowers quite early and brings many mag. nificent blooms. Price, packet 10c, post. paid.

Tall African. Grows tall and stately and, while rather slow, the blooms art very showy. Price, packet 10c, postpaid

\section{Larkspur}

One of the best flowers for beginner at raising flowers. Easily raised and fur nishes a large number of blossoms vary. ing from white thru blends of red anc blue. Price, packet 10e, postpaid.

\section{Morning Glory}

Grows anywhere and will climb to an: height if a support is furnished. Th many bell-shaped blooms of differen colors which grow over the entire lengtl of the vines make a very pretty signt Price, packet 10c, postpaid.

\section{Nicotiana}

A member of the Tobacco family, whic is easily grown and carries a wealth handsome blooms with a very pleasin odor. Price, wacket 10c, postpaid.

\section{Nasturtium}

A very popular flower which is easil grown upon almost any kin of soil an will dieep sending out blooms for a lon: time if the flowers are picked regularly Price, packet 10e, postpaid. 


\section{Pansy}

Our ancestors called this "Heart's Ease" and the name seems to be peculiarly fitted to the sentiment expressed by a cluster of fresh pansies.

Collossal. We have used this seed for three years upon our test plots and it produced the largest and finest flowers for us that we ever saw. Nothing produced from the same amount of labor will give the amount of pleasure to be derived from a bed of these pansies. Price, packet 25e, postpaid.

Giant Trimardeau. A hardy, vigorous variety which furnishes well rounded, many shaded flowers, usually marked with three blotches of contrasting colors. Price, packet 10c, postpaid.

White With Purple Eye. A select strain that has been bred to produce a striking flower described by the name of the kind. Price, packet 10c, postpaid.

Goldelse. A bright canary yellow flower upon a strong stem. Price, packet 10c, postpaid.

King of the Blacks. A flower which looks as tho the leaves were cut from black velvet. Price, packet 10c, postuaid.

Kewpie. Bronze center shading lighter towards the outside. Price, packet 10c, postpaid.

Mixed. Some of each of the named sorts. Price, packet 10c, postpaid.

\section{Petunia}

Should not be planted early but makes a quick growth if watered freely. Produces many blooms in all shades and hues of the rainbow. Price, packet 10c, postpaid.

\section{Snap Dragon}

This is an old favorite and the florists, by careful selection, have made a wonderful improvement in the blooms. Large spikes of odd shaped lobes with finely marked throats. Has a very pleasant perfume and while not very hardy, if the plants are protected from freezing and thawing, will survive the winter and bloom early next spring. Price, packet 10c, postpaid.

\section{Pinks}

The many shaded pink blooms that look like very fine cuttings of tissue paper surrounded by green foliage make a desirable addition to any garden or bouquet. Price, packet 10c, postpaid.

\section{Phlox}

For a splendid mass of elegant colors that will last many weeks, nothing is equal to a bed of phlox. Plant early and you will enjoy it a long time. Price, packet 10c, postpaid.

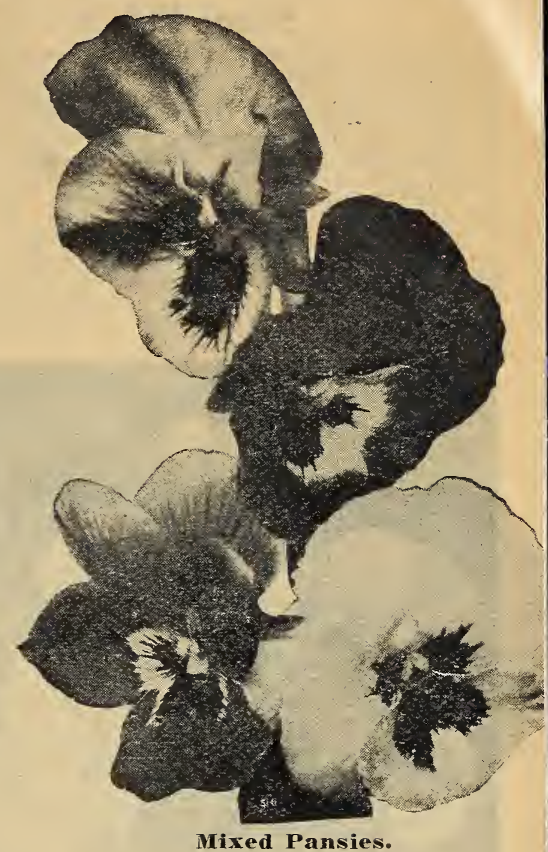

Poppy

The queen of flowers. A bed of bloo ing poppies always looks elegant and few of them in a bunch of flowers make look like "Ready Money." We hí selected the varieties best suited to northwest.

Carnation Flowered. Produces ma large sized flowers of different hues a colors. Price, packet 10c, postpaid.

California. A deep yellow bloom wh was adopted by popular vote in Califor as the state flower. Price, packet 1 postpaid.

Mixed. A combination of the stand sorts. Price, packet 10c, postpaid.

\section{Portulaca}

Also called "Moss Rose." This will gr and bloom where most plants perish account of dry weather. The foliage sembles a growth of moss and the bloo are the size and shape of a rose. T will satisfy the beginner in flower growi as it will produce a crop for little wo Price, packet 10c, postpaid.

\section{Stocks}

A very popular plant which does well pots or out of doors. Plants should started as tomatoes are handled and yield a large number of multi-color flowers with a fragrance second to nothi in the garden. Price, packet 10c, po paid. 


\section{Sweet Pea}

This is the most commonly grown flower. For best results, prepare a trench ten inches or a foot deep with a layer of rotted manure in the bottom and earth enough to firm and put seed into on top of the manure; then soak the seed over night and plant seeds three inches apart in the trench. A frame should be provided upon which the vines may climbthe sunny side of a fence being an excellent place to put a trench. If the blooms are picked every few days, a supply of beautiful flowers will be at hand the entire summer.

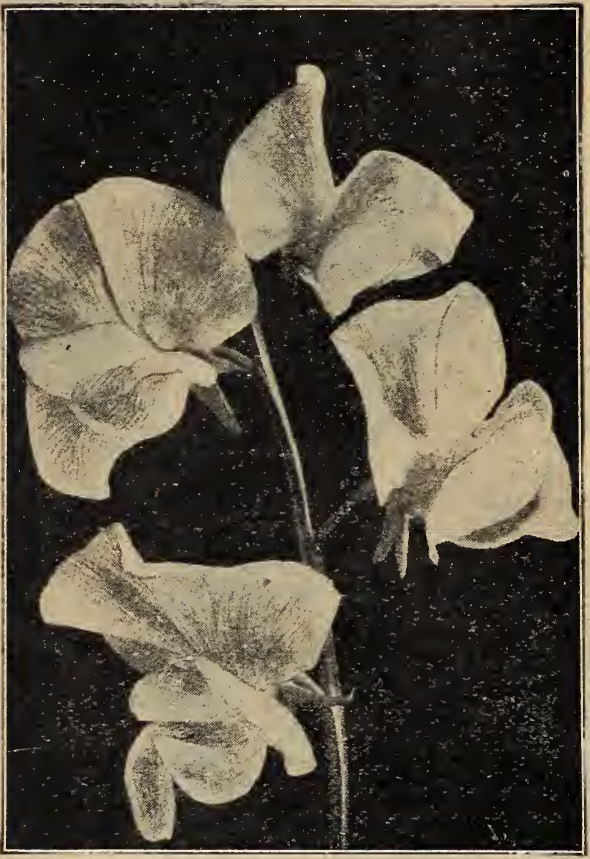

America Spencer Sweet Peas.

Spencer Type. These are the latest strains and will yield larger blooms than the common varieties.

America-Spencer. White striped with bright crimson. Price, packet 10c, ounce 25c, postpaid.

Captain of the Blues-Spencer. A very distinct purple. Price, packet 10c, ounce 25e, postpaid.

Countess-Spencer. A very delicious pink. Price, packet $10 \mathrm{c}$, ounce $25 \mathrm{c}$, postpaid.

Dorothy Eckford-Spencer. Pure white. Price, packet 10c, ounce 25c, postpaid.

King Edward-Spencer. Dazzling crimson. Price, packet 10c, ounce 30c, postpaid.

othello-Spencer. The nearest jet black which has ever been produced in sweet peas. Price, packet 10c, ounce 25c, postpaid.

Sterling. Stent-Spencer . Bright red. Price, packet $10 \mathrm{c}$, ounce 3 e, postpaid.

rixed spencer. Some of each of the named sorts. For general results this will be found a most satisfactory seed. Price, packet 10c, ounce 25c, postpaid.
Grandiffora Type. They do not grow quite so large as the spencer but many people prefer them.

Blanche Burpee. Fure white. Price, packet 10c, ounce 20c, postpaid.

New Countess. A delicate lavender. Price, packet 10c, ounce 20c, postpaid.

Dark Knight. Very dark purple. Price, packet $10 \mathrm{c}$, ounce $20 \mathrm{c}$, postpaid.

Firefiy. Brilliant red. Price, packet 10c, ounce $20 \mathrm{c}$, postpaid.

Kathryn Tracy. Soft pink. Price, packet 10c, ounce 20c, postpaid.

All Colors. A pleasing mixture of popular strains. Price, packet 10c, ounce 20c, postpaid.

\section{Sweet William}

This has been grown in permanent flower gardens for more than a century. Does not bloom the first season, but if given a little care will not winter kill and one planting lasts six or eight years; after the first season it blooms early and late. The flowers are handsomely colored and marked and borne upon stiff stems in great profusion, forming dense round heads or clusters, often four inches across. The colors are exceedingly varied, ranging from white thru many shades of red and blue to nearly black, usually two shades in each plant. Set six inches apart they make a handsome border, or they may be gr $\diamond w n$ in beds.

We offer a particularly hardy strain.

Diadem. Price, packet 10c, postpaid.

\section{Wall Flower}

Something for the long months when the only flowers seen out of doors are the frost figures. Start the plants indoors quite early in the spring; when three inches high, transplant into pots; after danger of frost is over set out in the garden; before frost in the fall, take the plants up and set into pots and put them in a sunny window. You will have handsome flowers all winter.

Triumph. A distinct blood red blossom of large size and velvety texture borne upon a sturdy stem. It will do your eyes good. Price, packet 10c, postpaid.

\section{Wild Cucumber}

A wonderful climber which will cover the porch or fence with beautiful foliage which lasts all summer. Price, packet Ive, ounce 25e, postpaid.

\section{Verbena}

This is one of the surest blooming flowers raised in the northwest. The blooms grow in clusters often three inches across and have a pleasant aroma.

Hybrid Mixed. A wide range of colorswhite to dark purple with nearly all of the shades between. Price, packet 10c, postpaid.

\section{Zinnia}

The stems grow to 18 inches high and bear blooms that are a large ball of curled, twisted leaves of brilliant hues. This is a very showy flower and an ornament for any garden. Price, packet 10c, postpaid.

The seed of Verbena and Zinnia is very hard and should be soaked at least 24 hours before planting. 


\section{DECORATIVE PLANTS}

While a great variety of flowers and plants may be grown out of doors in a single season from seed quite a number must be started in the house or under glass. Our green house is in charge of experts who have studied and know the best strains to start and the best methods of starting them and we are particularly confident that you will be well pleased with the plants which we offer here if you favor us , with an order for some of them.

\section{SUMMER FLOWERING BULBS}

Gladiolus. Good mixed, named varieties. Price, per dozen $\$ 1.00$, postpaid.

Gladiolus. Extra fancy, in either white, red, pink or blue. Price, per dozen \$1.25, postpaid.

Cannas. Dry bulbs. Price, each 20c, postpaid.

Cannas. Started plants. Price, each 30e, postpaid.

Dahlias. All colors, dry bulbs. Price, each 25e, postpaid.

Cinnamon Vine. Price, each 10c, postpaid.

Maderia Vine. Popular climbers. Price, per dozen $\$ 1.00$, postpaid.

Peony Roots. Best sorts (state color). Strong roots. Price, each 50e, per dozen $\$ 5.00$, postpaid.

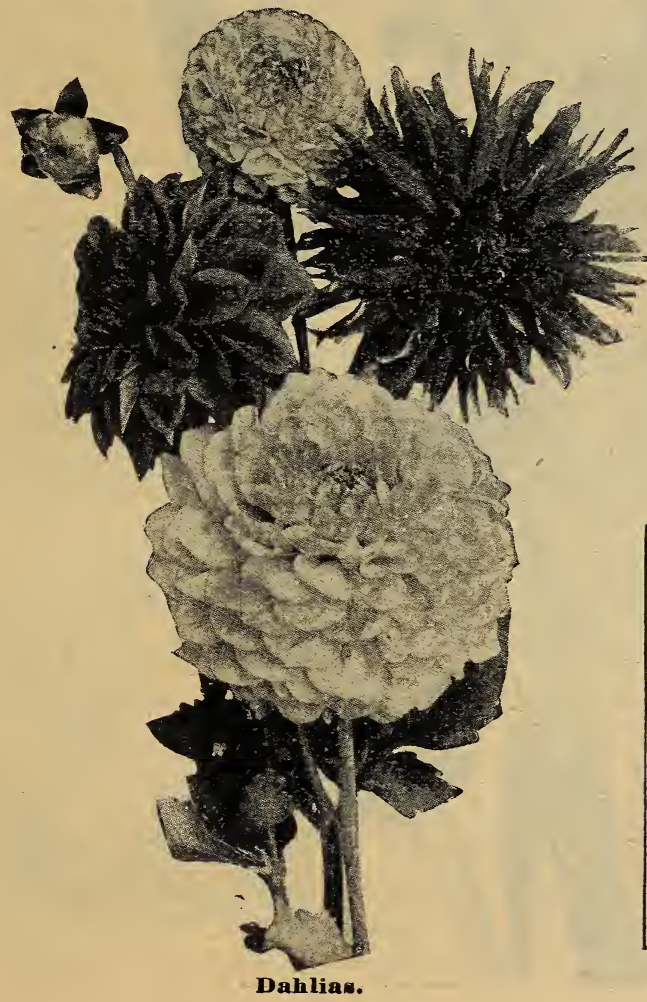

Northern Seed Co., Valley City, N. D.

I have used your seeds three years and have had fine gardens every year. The White Wax Beans are fine.

Grenora, N. D. - Mrs. Glenn D .Isaacson.

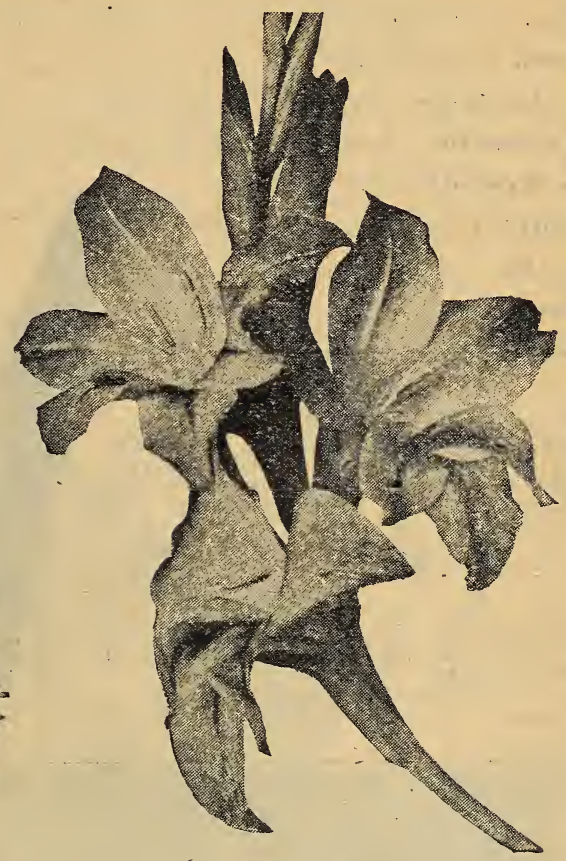

Gladiolus.

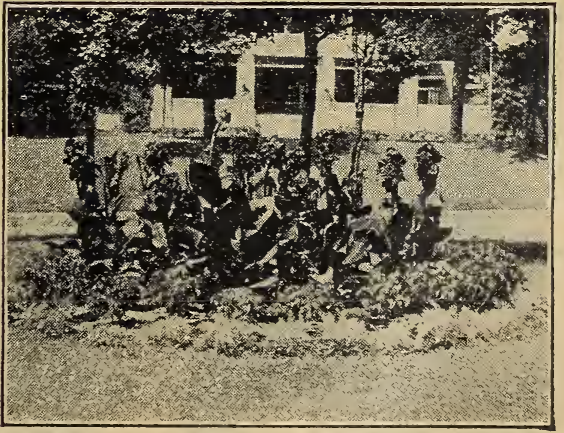

Cannaø. 


\section{WWRING BULBS FOR} FALL PLANTING

the parent stock of nearly all these must be imported, the unsettled con1 of foreign markets and the unceres of transportation make it impossiquote prices upon these goods. We he varieties now in stock-and we to be able to carry these as well as thers obtainable and will ask that rrite for quotations upon your wants lbs. We will be pleased, at any time, rise you concerning our stock and the

fodils. Dóuble yellow.

eissus. Paper white.

ch Hyacinths. All colors, first size. eh Hyacinths. All colors, second size. an Hyacinths. White.

a Lily. Bulbs.

ter Lily. Bulbs.

esias.

ern Seed Co., Valley City, N. D. lank you for the prompt attention my order for your garden seeds. used your seeds for two years and :hem excellent. Am sending you ir order. From,

Mr. and Mrs. Fred Huguet. N. D., R. 2, Box 9 .

srn Seed Co., Valley City, N. D.

ve used your seeds for five years and not use any other.
), Mont.
Yours for success,
Fred Hohndahl.

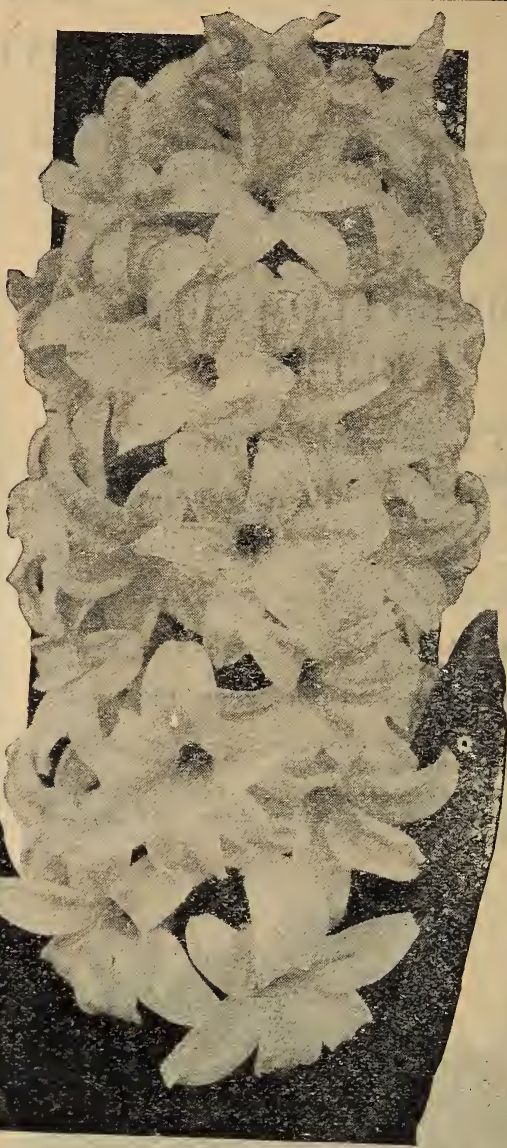

Hyacinth.

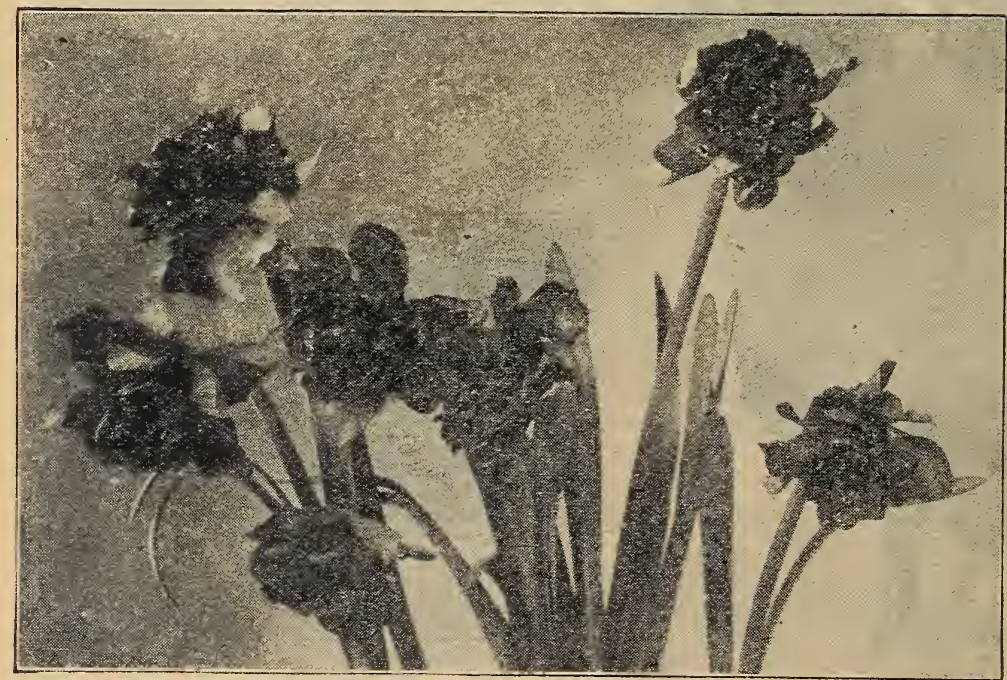

Nareissus. 


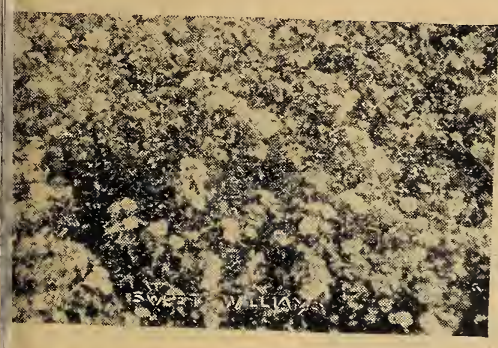

Sweet William.

\section{IARDY PERENNIAL} PLANTS

ior Fall and Spring Planting)

y Aster. Purple flowers, strong Price, each 35c, postpaid. psis. Tall yellow flowers. Price,
e, postpaid.

ily. Yellow. Price, each 35c, post-

hum. Assorted colors. Price, each tpaid.

a Daisy. Price, each 35e, postpaid. t-Me-Not. Price, each 20c, postHove. Price, each 35e, postpaid. rdia. Price, each 25c, postpaid. , Glow. Price, each 35e, postpaid.

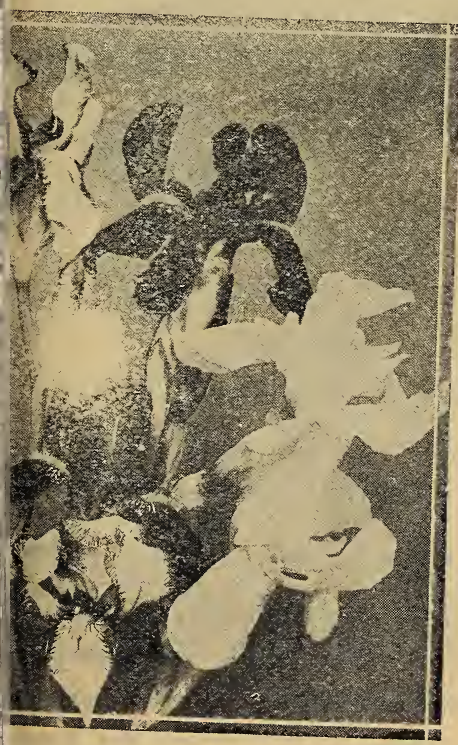

Iris.

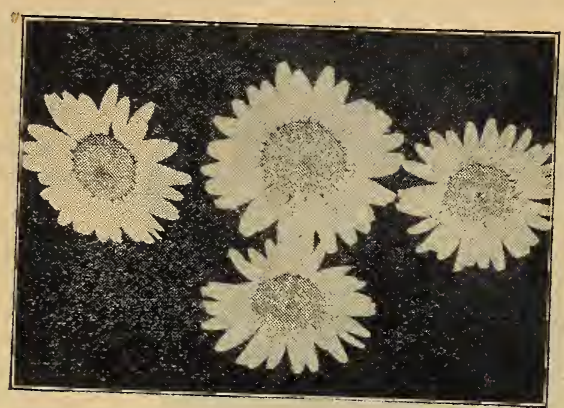

Shasta Daisies.

Hollyhock. Price, each 25e, postpaid.

Iris. Blue and yellow varieties. Strong plants. Price, each 25c, postpaid.

Larkspur. Large clumps, assorted colors. Price, each 50c, postpaid.

Hardy Lillies. Price, each 25c, postpaid.

Oriental Poppies. Assorted colors. Price, per dozen $\$ 2.00$, postpaid.

Sweet William. Price, per dozen \$2.00,
stpaid.
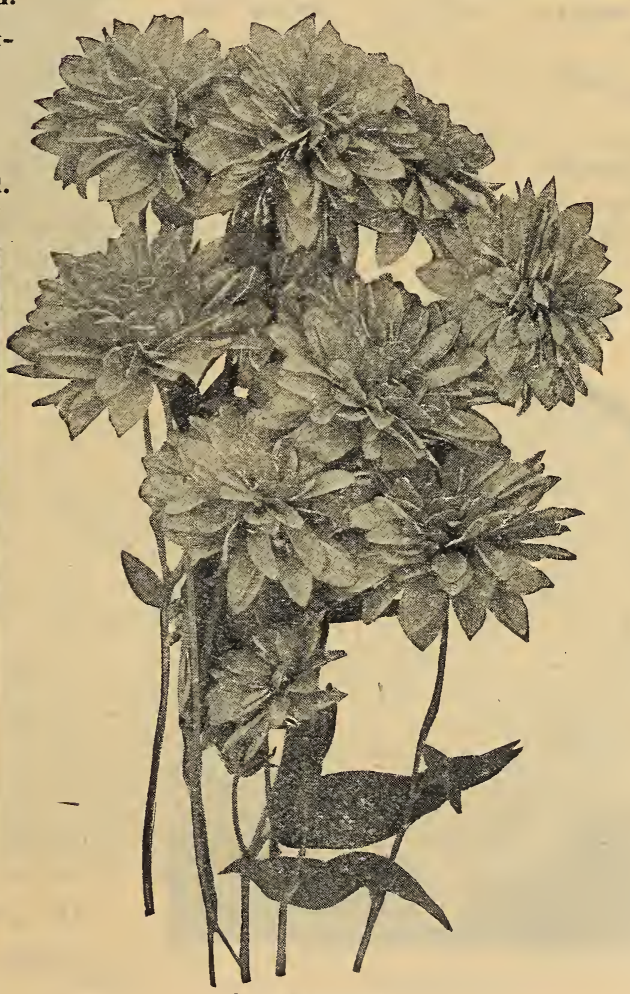

Golden Glow. 


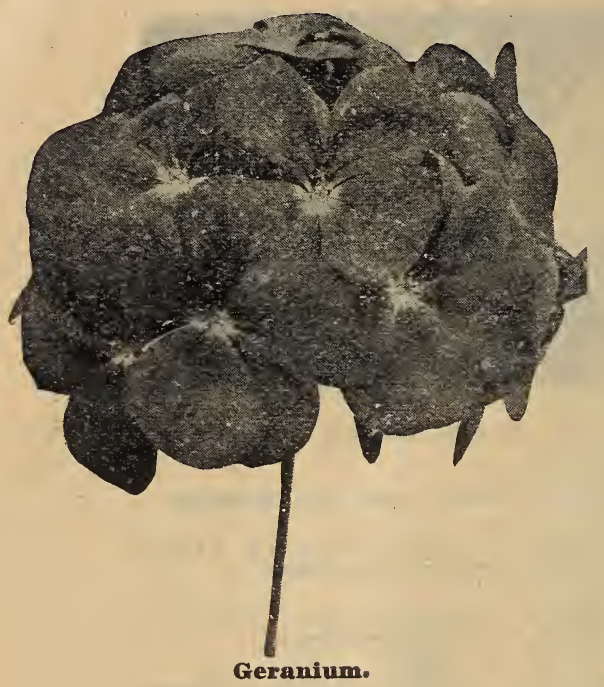

Geraniums. Standard varieties. Price, per dozen $\$ 4.00$.

Geraniums. Fancy leaved varieties. Price, each 50c.

Geraniums. Pelargonium or Lady Washington. Price, each t5e to $\$ 1.00$.

Marguerite Daisies. Price, each 35c.

Lobelias. Pretty for border plants. Price, per dozen \$1.00.

Salvia or Scarlet Sage. Large plants Price,.Per dozen \$1.50.

Heliotrope. Four inch pots. Price, each 35e.

\section{SPRING BEDDING PLANTS}

(For the Flower Bed, Porch Box and Window Garden)

Aster Plants. Seedlings. Frice, per dozen 35c.

Aster Plants. Pot grown. Price, per dozen 75e.

Ageratum. Purple and white, for borders. Price, per dozen \$1.00.

Alyssum. Price, per dozen 35c.

Coleus or Foliage Plant. Price, each 15e.

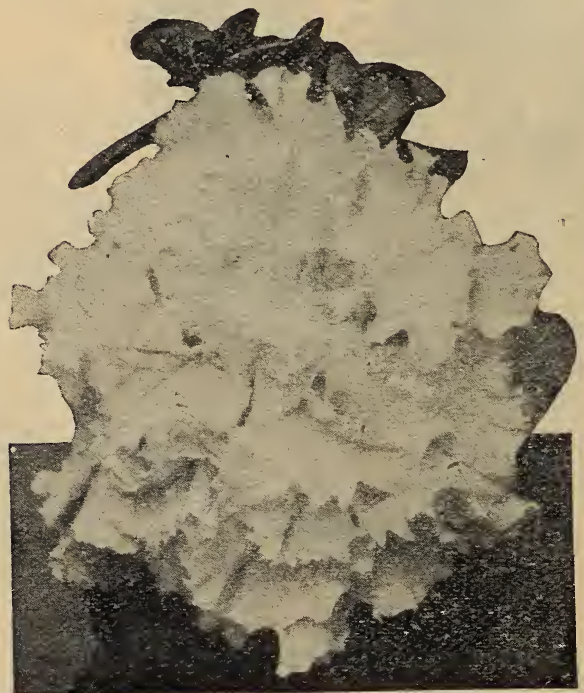

Petunia.

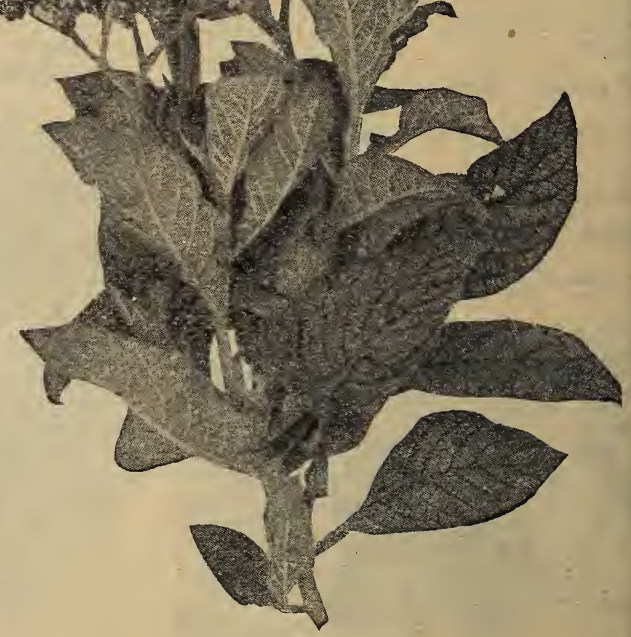

Heliotrope.

Heliotrope. Three inch pots. Price, each 20c.

Verbena. Price, per dozen 75c.

Feverfew. Large plants in bloom. Price, each 35e.

Pansy Plants. Finest strain. Price, per dozen 50c.

Petunias. Double. Price, each 25e.

Petunias. Single. Price, dozen 35e.

Phlox Rrummondi. Price, per dozen 35e.

stocks. Ten weeks. Price, per dozen 35e. 


\section{DESIGN WORK}

Our florist makes a specialty of this class of work and we are ready at all tim Our florist makes a specialty
to furnish any of the designs listed on short notice. Flowers or designs are packi
to reach you in perfect condition regardless of extremes of temperature.

Wreaths of assorted flowers, according to size............. \$ 6.00 to $\$ 20$.

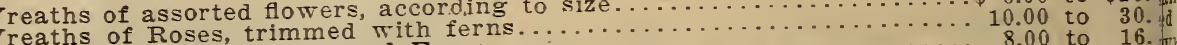

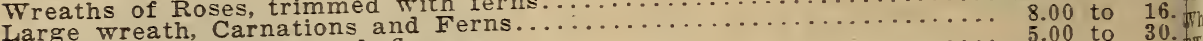

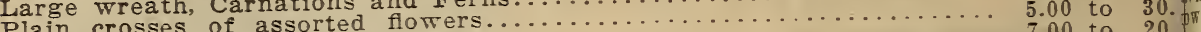

Maltese crosses, Casket crosses, etc.......................... 7.00 to 20. lee

Standing cross on large mounted base ........................ 15.00 to 30.

Standing Harp or Lyre, 2 to 3 feet in height ......................... 100 to

Broken Wheel on easel, 18 to 24 inches in diameter................ 10.00 to

Broken Column, 20 to \pm 2 inches high............................ 8.00 to

Stars, Hearts, Shields, etc..................................... 7.00 to

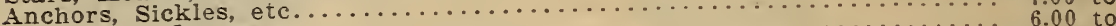

Baskets of flowers................................................ 200 to

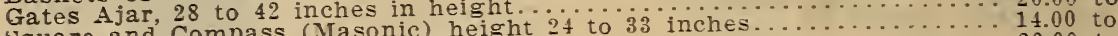

square and Compass (Masonic) height 24 to 33 inches................ 20.00 to

Cross and, Crown (Masonic), width of crown 14 to 20 inches............. 10.00 to

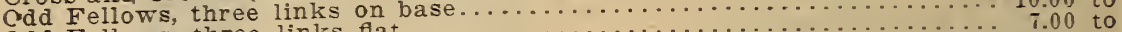

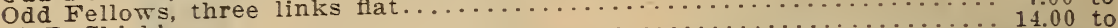

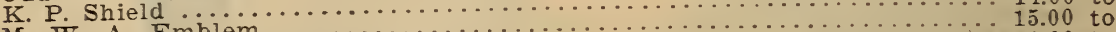

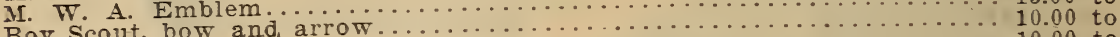

Boy Scout, bow and arrow......................................... 100 to

Yeoman Shield..........................................

Bouquet of Roses tied, size varies with number of blooms............ 2.00 to

Spray of Carnations, tied.

\section{CUT FLOWERS}
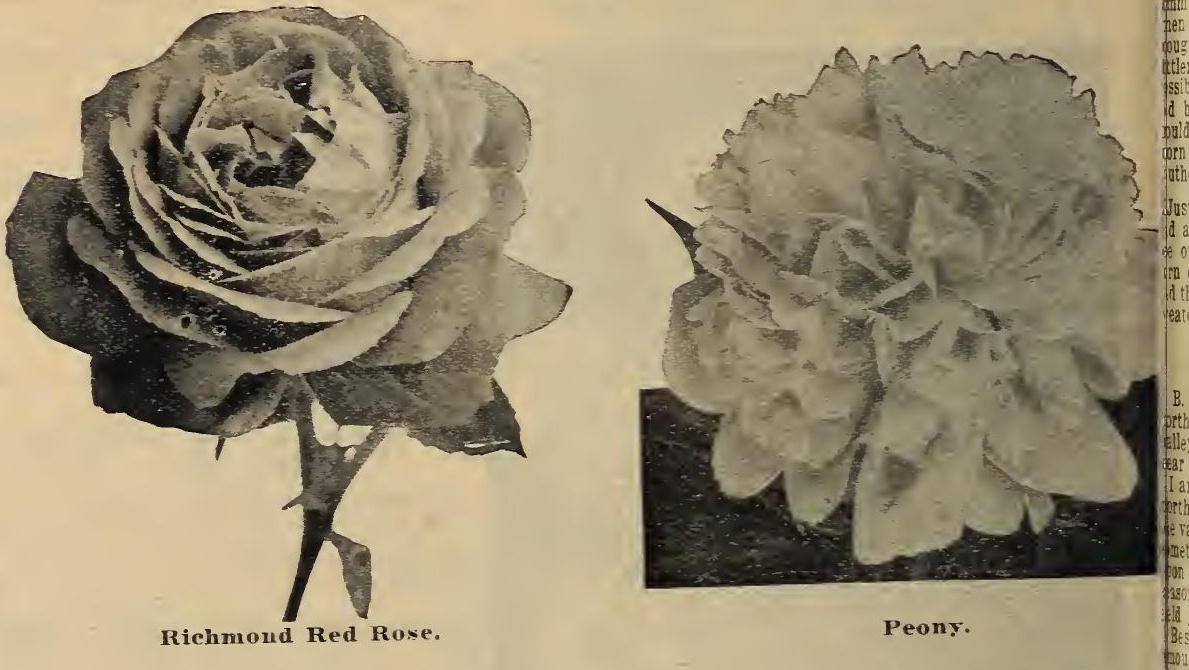

We can supply choice cut flowers of the kind named during the months nif These flowers are grown here at Valley City, our service is quick and stocks alr fresh.

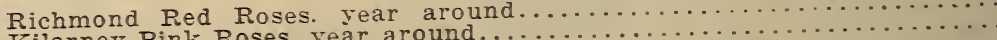

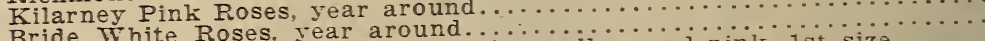

Carnations, red, White and pin.

Smiax, per string, Yov. to Feb.

Tulips, all colors, Jan. to June

Daffodils, yellow, Feb. to May.

Gladiolus, April to Sept.

Peonies, May to June.. 


\section{SEED CORN}

rof. W. M. Hays, one of the leading farm experts of the country, says: "The inherited lity of corn to yield heavily or poorly all comes in the ten pounds, more or less of d pianted. to the acre."

When you buy seed corn from us you get the benefit of our years of experience in wing, selecting and curing seed. We do not claim always to offer the cheapest in e, but we do claim to offer the best seed at any price and that our prices are cheapest rields and not first cost gre considered.

n Iowa and Illinois "Corn is King" and values have gone from forty dollars acre to two hundred fifty dollars per e. A farmer, discussing this matter "Those acres will raise no more grain hay than when they sold for forty lars. I dot understand, how the farmers in there make ends meet."

'he explanation is that the methods of ming have changed and now the farmer in the high priced lands raises different ps and instead of selling grain and hay s robbing his farm of its fertilityis milk, beef, pork and poultry and ains the fertility which the crop took $m$ the soil in the manure which is put lik upon the farm.

i) ne of the first steps in this change of thods of farming was raising corn. thin the memory of men in every nmunity in the northwest is the time en central and northern lowa were ught too far north for corn by the tlers there. But time proved that corn, ssibly not the same varieties whir i been raised "back east" and south, uld mature in all of Iowa and the "rn belt" moved up thrcugh Iowa, Ithern Minnesota and South Dakota.

rust now, North Dakota is on the edge 1 as we learn to raise corn and make : other changes which will come with - $n$ crops, land values here will increase the returns from the land will become zater accordingly. But we must have a kind of corn which will mature in our shorter season and which grows so that ii may be harvested with machinery to make the crop profitable.

In North Dakota White Dent the Northern Seed, Company offers to the trade the corn for this country.

tures ten days earlier than Northwestern Dent. The past season the crew commenced picking the seed which we are offering the first of September and our tests show perfect germination of the seed. The ears are six to ten inches long, three inches in diameter and contain fourteen rows of deep, close fitting grains with a very small cob.

An Illinois corn man who saw our stock october 12th declared that the corn was cured enough then to grade No. 1 upon the Chicago market. The stalks grew five and a half to nine feet tall and have a heavy foliage making a heavy crop of forage in addition to the grain. The ears, two, three, four, five, upon each stalk are fifteen inches to two feet from the ground giving plenty clearance for a corn binder or picker.

We are especially proud of our stock of this corn which was raised for us upon a farm adjoining Valley City and urge that you join the procession towards better farming by planting a liberal field of this corn this year.

Price, 1/4 bushel \$1.50, 1/2 bushel \$2.50, bushel $\$ 4.50$, by freight or express at purchaser's expense, sacks extra, 65 e eaca.

\section{B. Cox, Manager,}

rthern Seed Company,

lley City. North Dakota.

ar Mr. Cox:

a pakota should plant almost exclusively the rth Dakota White Dent Seed Corn. For several years we have experimented with various kinds of corn recommended and grown in this section but nearly every year mething happens to the other varieties. We have found however, we can depend on growing the North Dakota White Dent and bringing it to a fairly good maturity ason after season. This year we could husk our North Dakota White Dent in the id just the same as the Kansas farmer husks his.

Besides this, it is a high grade corn, small cob and deep kernel, with a fairly good lount of fodder. We suggest that you advise and urge your customers to purchase d plant the North Dakota White Dent exclusively, as we mean to do on the Northwest irsery Company's ground, for our own feed.

Respectfully yours,

E. C. Hilborn,

Sec'y. The Northwest Nursery Co.

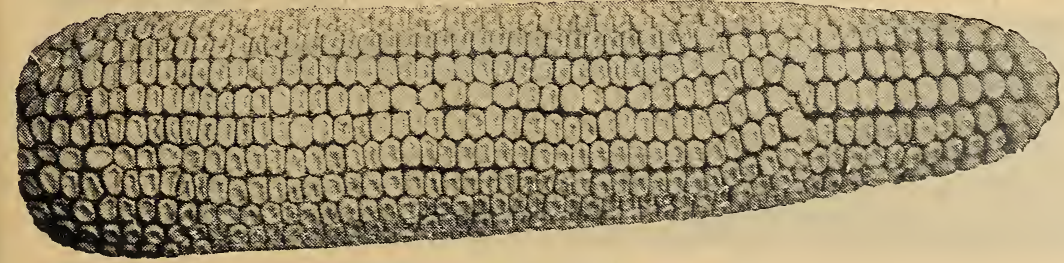

Vorth Dakota White Dent.

Prices Subject To Change Without Notice. 


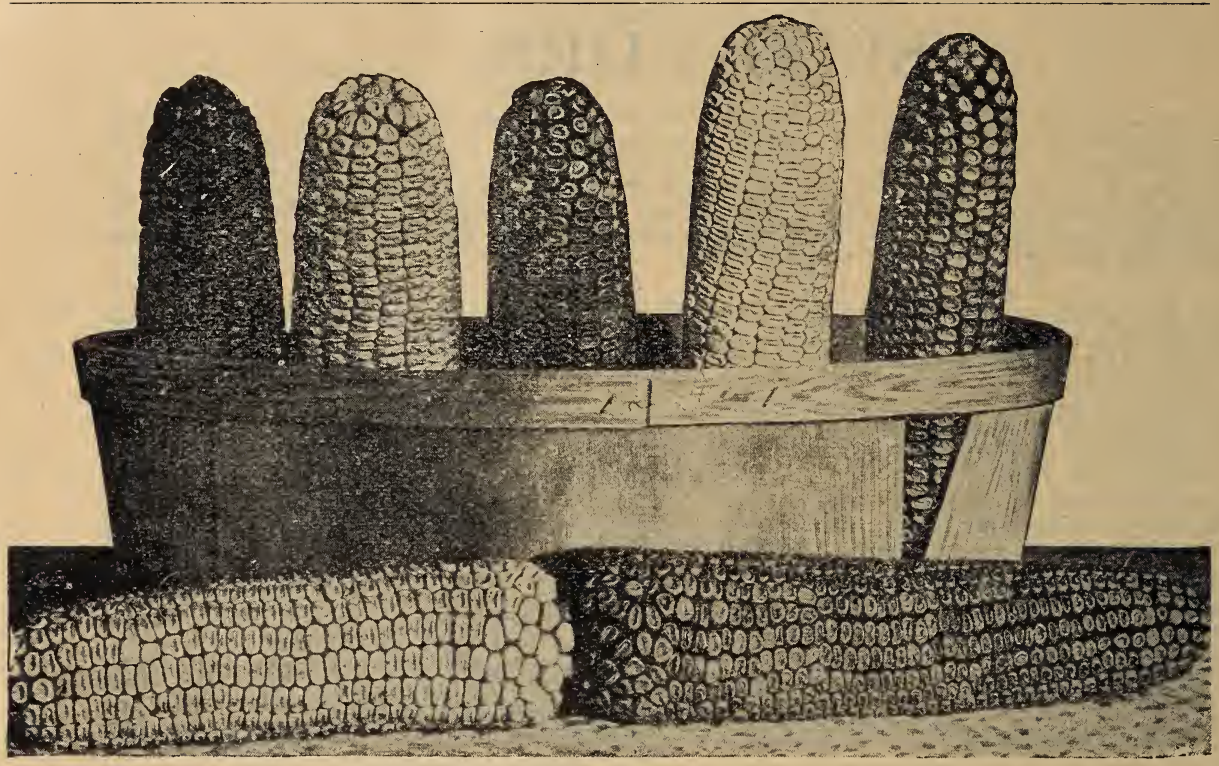

Northwestern Dent.

\section{NORTHWESTERN DENT}

This is a cross between a red flint and yellow dent corn and was the first dent corn which could be depended upon to mature a crop in the northwest. For this reason, it is the most extensively grown dent corn in our territory today. Ripens in one hundred days, under ordinary conditions and produces stalks about seven feet high. with ears well-up from the ground. The grains are red with yellow cap. Though not a handisome corn, it has many friends because in past years it produced a crop where other dents failed.

Our seed is North Dakota grown, carefully dried and tests better than $90 \%$ germination. Price, $1 / 4$ bushel \$1.50, 1/2 bushel $\$ 2.50,1$ bushel $\$ 4.00,2$ bushels or more at $\$ 3.50$ per bushel, sacks, 65e each.

\section{MINNESOTA 13}

A variety of corn óriginated by Prof. W. M. Hays while in charge of the Minnesota State Experiment Station. In recognition of his work for northwestern farmers, Prof. Hays has since been made Assistant Secretary of Agriculture at Washington, D. C. The authorities in Minnesota and other experiment stations consider the origin of Minnesota 13 as his greatest contribution to this section.

The ears are of handsome appearance bearing 16 to 20 rows of bright rich yellow smooth wedge shaped kernels packed closely upon the cob from tip to butt. Ears average eight inches long and usually two on a stalk. No corn excels in quality Minnesota 13; the cobs are well filled and the individual kernels plump and of good color. Stalks grow about seven feet tall and are leafy, making excellent nutritious fodder. We have North Dakota grown seed. Price, $1 / 4$ bushel \$1.50, $1 / 2$ bushel $\$ 2.50,1$ bushel $\$ 4.00,2$ bushel or more at $\$ 3.50$ per bushel, sacks, 65 each.

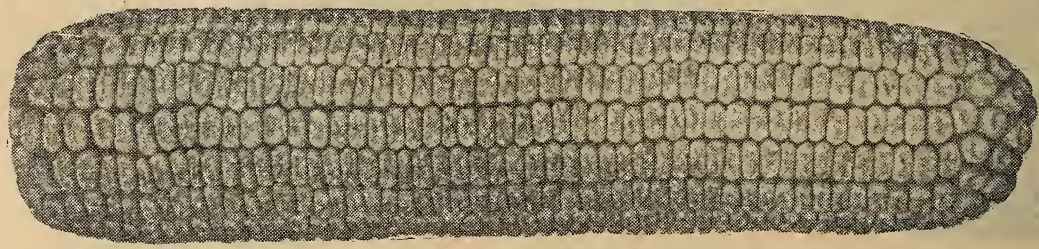

Minnesota 13.

Prices Subject To Change Without Notice. 


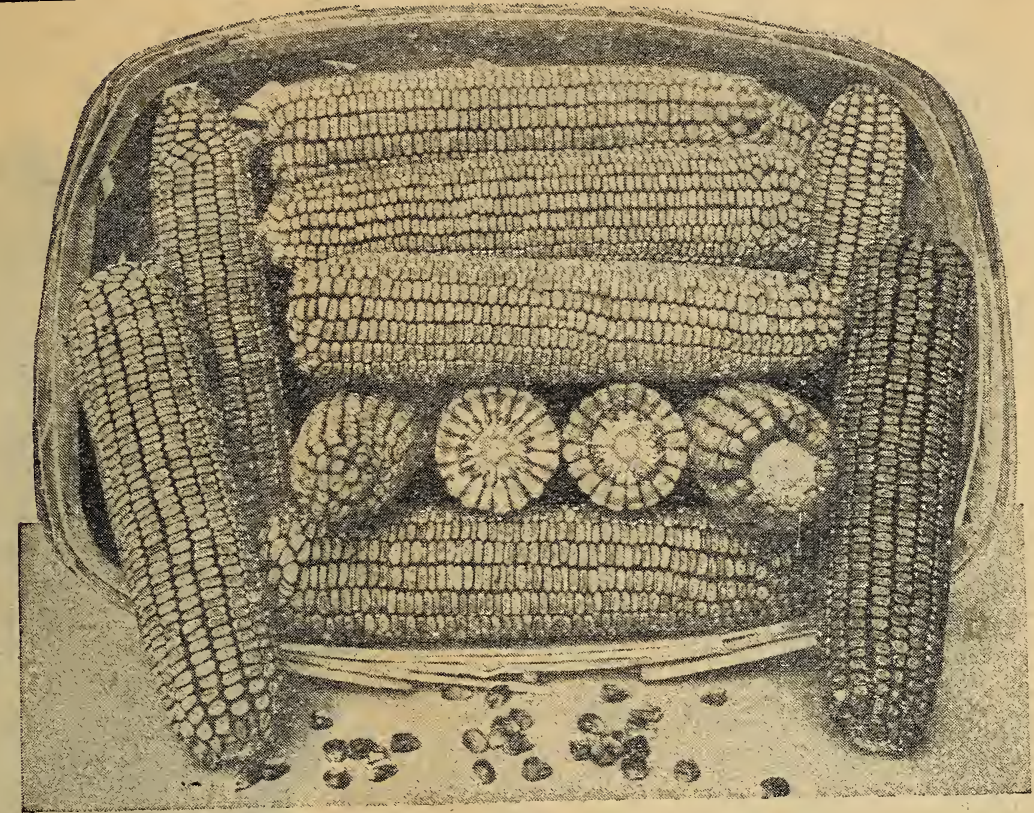

White Rustler.

\section{WHITE RUSTLER}

This is the parent of our North Dakota White Dent. The strain is of northern origin and yields an early crop of excellent corn with a heavy growth of fodder.

White Rustler will grow and mature under more unfavorable conditions than any other variety of dent corn. Our stock of North Dakota grown seed germinating $95 \%$ is the best seed that can be planted by any farmer. Price, 1/4 bushel \$1.50, 1/2 bushel \$2.50, 1 bushel \$4.00, 2 bushel or more at \$3.50 per bushel, sacks, 65e each.

\section{FLINT CORN}

Before we had a dent corn which would mature in the Northwest there were flint matur being ripened here year after year. Because of this fact, many of the pioneers declare that flinit is the corn of our country.

Flint corn is earlier than dent but does not have as much foliage and yields less fodder if you want nothing except corn, plant flint.

We have selected three varieties of flint and can assure you that either of them will produce a crop of ripe corn in an ordinary year.

\section{NORTH DAKOTA WHITE FLINT}

An exceptionally early North Dakota grown flint. It does not grow quite as large and the ears are not so long as other kinds, but it always ripens.

Plant a few acres of this and when the hog pasture is dried out turn your pigs inito the flint corn. They will clean up the corn and most of the fodder. You will be surprised at the growth young hogs will make, or the flesh old hogs will put on while running in the corn. This saves much work feeding hogs through the busy fall, puts a "finish" upon the hogs and harvests the corn leaving ground, ready for next crop. Price, \$4.00 per single bushel, 2 bushels or more $\$ 3.50$ per pushel, sacks extra, 65e each.

\section{GEHN FLINT}

A yellow flint corn which grows rather iarger than North Dakota White Flint but yields a heavy crop of golden yellow grain.

Seed grown in North Dakota, carefully selected and tested. Price, \$4.00 per single bushel. 2 bushel or more at $\$ 3.50$ per bushel, sacks extra, at 65c each.

\section{SQUAW FLINT}

In 1804-5 President Jefferson sent Lewis and Clarke to explore the newly acquired Louisiana Purchase which France had ceded to us. The explorers wintered with the Mandan Indians and found them eating corn which had been raised, with the iew hand-made tools the squaws could manufacture. The corn which these Indians were raising had been grown in the Northwest ever since the white men had any knowledge of the country or its inhabitants. When the first settlers came to the country, they got seed from the Indians and selection and breeding of this original stock has developed what we offer to the trade as Squaw flint.

A very early flint, small stalks, two to four ears upon each stalk. Corn varicolored often three colors upon a single cob. It is the earliest ripening corn ever sold and is especially good for hogging off. Price, \$4.00 ver single bushel, 2 bushel or more at $\$ 3.50$ per businel, sacks extra. at $65 \mathrm{c}$ each. 


\section{FODDER CORN}

This is planted where a heavy crop of forage is wanted and little or no grain expected. We supply southern grown seed and ten foot stalks in ten weeks is not uncommon. If planted thick, the stalks do not get too large and ten tons of cured fodder, all of which is palatable, will grow from a single acre.

Large Yellow Dent. Makes a very rapid growth. A tall, many jointed stalk with wide leaves. Price, \$2.50 per bushel, sacks extra, 65e each.

Red Cob Fodder. A white grain grown upon a red cob which makes a wonderful growth of stalk and leaves in short time. Price, \$2.50 per bushel, sacks extra, 65c each.

\section{SWEET CORN FODDER}

Many of our customers raise for roughage, sweet corn which is cut and cured, then feed cobs and fodder. They clalm this makes better fodder than the regular field corns. We offer a medium early sweet corn which makes rank growth of fodder and produces many ears. Write for prices.

\section{AMBER CANE}

This is a sorghum plant of the same family as the sugar producers. It should be seeded when the ground is well warmed in the spring and best results are obtained from planting in rows wide enough apart for cultivation, using 12 to 15 pounds of seed per acre. If cultivated as corn should be, five or six tons of fine hay may be harvested from each acre. The stems are small and juicy while the broad leaves cure into a most desirable fodder. Cut it with the grain binder and stand the bundles in long "V" shaped shocks then leave the shocks until the hay is wanted for feed in the barn or lot. The cane leaves and stalks contain so much sap that it is hard to preserve the fodder if put into stacks before thoroughly dried, but the shocks can stand thru the winter without injuring the fodder. The bundles are smooth as wheat or oats and catch very little snow; corn shocks always bother catching snow and freezing down.

Our local sale of Amber Cane seed has increased from 500 pounds in 1910 to 25,000 pounds last season. Every farmer who plants a small patch and a number of his neighbors who observe the crop and the results from feeding it, each want a larger field next year. Price, \$5.00 per liundred by freiglit or express at purchaser's expense.

\section{OATS}

In all nature, nothing stands still. Your seed this year is either better or worse than last year. Oats, if grown year after year from the same seed upon the same soil, "runs out," and this stage has been reached in this country by the old strains.

A few years ago, Hickox-Rumsey Company of Batavia, New York, obtained from the Royal Agricultural Station of Sweden, a supply of Victory Oats, a new variety, which had been bred there. This was a very heavy oat with a light chaff. We sold a car load of seed raised by this firm in the vicinity of Valley City for planting in 1919. The yield as reported by our cus-

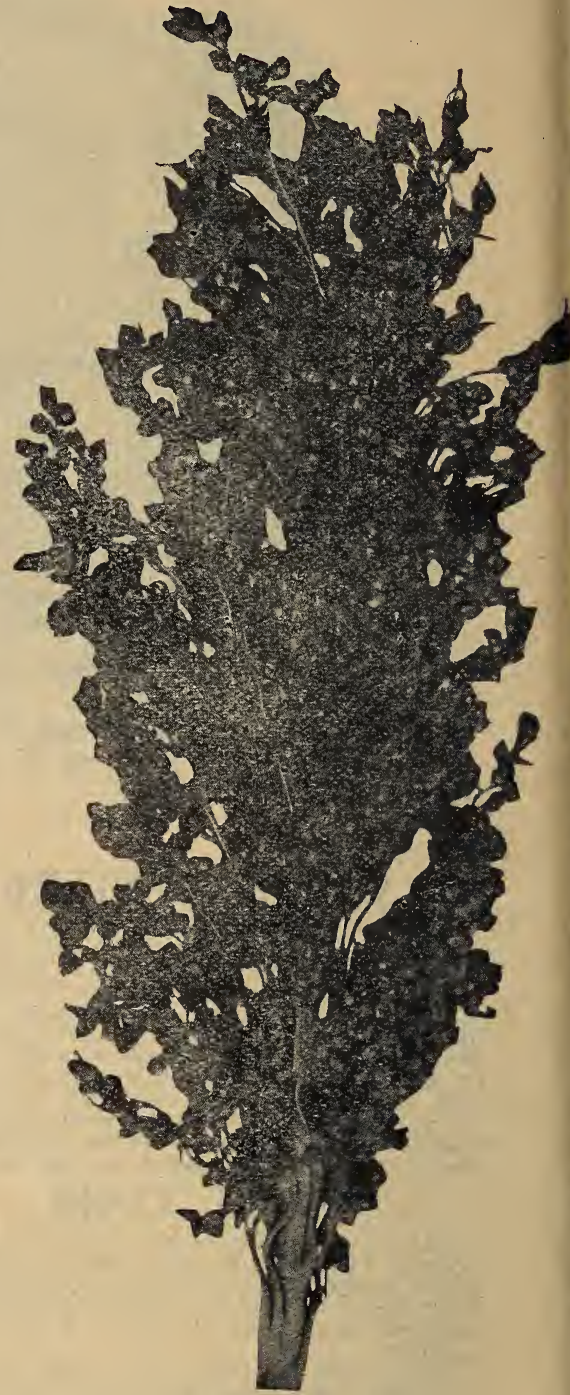

Early Amber Cane.

tomers was from thirty-three and onethird to $100 \%$ more than from the other oats planted upon the same farms.

We have a stock of this new Victory Oat raised in Barnes county in 1919 from seed just three generations from the first importation. This seed has been thoroly cleaned and is the best oats raised in North Dakota the past season. They ripened earlier than other oats in the country and are very desirable seed. A small patch of these will yield seed for the average farm the next year. The increase in crop over ordinary seed will pay for the new seed and give you a change of seed. with no cost. Price, single bushel \$2.00, 2 bushel more at $\$ 1.75$ per bushel, sacks extra, 65e each. 


\section{Silver Mine Oats}

This variety has given remarkable crops during the past five years to our trade. Matures in 95 to 100 days. The seed is white and much in demand for breakfast foods. Price, \$1.50 per bushel, sacks extra, b5e each.

\section{White Russian Oats}

A long, white, thin skinned berry borne upon very stiff straw. This variety is much earlier than others upon the market and will yield a fair crop under adverse conditions and a bumper crop under favorable conditions. Price, \$1.50 per bushel, sacks extra, 65e each.

\section{FLAX}

When wilt commenced to destroy the flax crops, North Dakota farmers, to a large extent, quit planting flax. The authorities at the agricultural college have developed strains of flax which are practically immune from wilt, so the old objection to raising flax can be overcome. Never before in the country's history has the price of flax been so high and there seems little prospect of any great reduction for some years to come. Pulp wood is being usel in America four times as fast as the trees grow. This means that in a few years the supply of pulp woods will be exhausted and some substitute must be found. Flax straw makes a better paper than pulp and can be used for all the purposes to which the by-products of the paper mills are put. This season, buyers are paying $\$ 10.00$ per ton for flax straw loaded upon cars at many stations over the state and they claim there is a demand for scores of times the amount of flax straw that is now raised.

This will mean a new industry for the state and money for every farmer who is ready to get his share. If you have not raised flax, put in a small field this year and have wilt resistant flax for sale or seed next season and save the straw. It will be worth money.

We have contracted for the crop from a number of fields but the price we will pay will be determined by the market when it is delivered to us. Please write for prices.

\section{ODERBRUCKER BARLEY}

Because barley is the chief grain crop of : a large part of Wisconsin, the State Experiment Station there spent much time and labor developing a superior strain of barley. They sought a heavy yielder which was rich in protein-this being the greatest chemical element desired in food.

Prof. Moore, of that station, declares that Oderbrucker barley yields ten bushels more per acre than any other variety tested and has a higher protien content than the others. He concludes his report with this statement: "In stiffuess of straw and rust resistance it is superior to all

We obtained a supply of this seed from Wisconsin some years ago and offer pure bred, elean seed, thoroly acelimated. Write for prices.

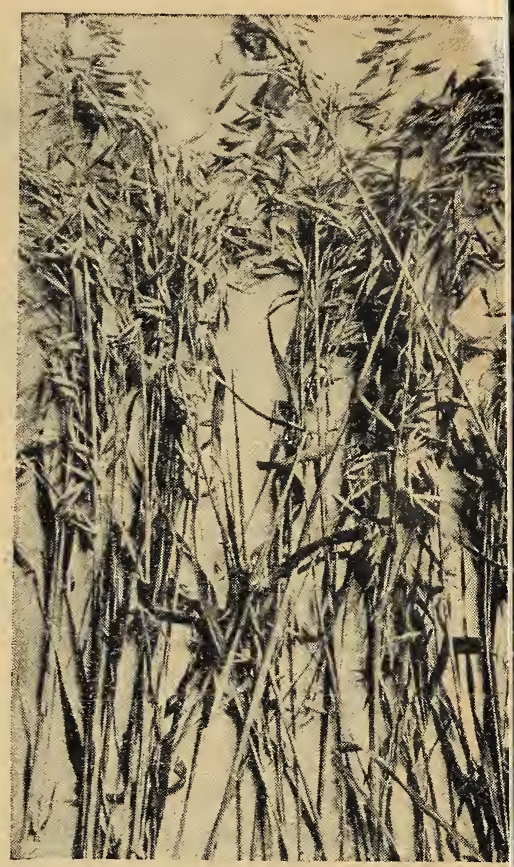

Victory oats.

\section{SPELTZ}

This can be grown in a shorter sea and upon poorer soil than any other the feed grain crops of the Northwes

It matures in a shorter season than of the feed crops and yields a heavy of most excellent feed.

Write for sample and prices.

\section{RAPE}

Plant five to ten pounds broadcast $u$ rich soil. Rape makes a very rapid gro and may be pastured six weeks af having two or results are obtained one while the or more fields and pastur

Rape is one of the turnip family grows leaves instead of roots. The brc leaves contain more water than most $p$ : ture crops; this makes the leaves tens and the stock will devour large or sm leaves. The dry matter in the leaves cc tains a larger percentage of protein muscle builder) and ash (the bone build than any other green crop grown. T] makes rape pasture the best for growi pigs, sheep, calves or colts. The lear taste good and supply the elements nece sary to keep the young stock growir Three five-acre tracts will carry two ku dred growing hogs from June 1st un snow flies and furnish "roughage" up which they may run while being finish for market. Price, 1 pound 25e, postpa pounds. 


\section{WHEAT}

Last season thousands of acres of wheat that looked like a "bumper crop" July first were not cut because the rust attacked the crop and the heads failed to fill. A large acreage which was cut did not yield enough grain to pay for harvesting and threshing.

Here in Barnes county, upon one side of the road could be seen a field of marquis or blue stem not harvested while the other side of the road upon similar soil, plowed and planted in the same way, was a field of D 5 which threshed tweny or more bushels per acre.

D 5 is a variety of wheat discovered by the agents of North Dakota Agricultural College in siberia. It is practically rust proof-a firm, hard wheat borne upon a stiff straw which stands clean while the ordinary wheat straw becomes spoted with rust and soon "crinkles" down.

When durum wheat was first introduced in this country, the millers claimed it would not "mill" and for a few years paid a much smaller price for it than for the fife or blue stem. But as soon as durum became generally known, the millers, wh. had always bought it, decided it would make flour and during many seasons pay a premium for it over fife or blue stem. At present, the same millers make the same claims concerning $D 5$ that were made against durum. But if it is raised generally, will not the history of durum be repeated?

But if the millers always buy D 5 at a slight discount, would it not be profitable to raise twenty bushels per acre of wheat to sell a few cents per bushel less than tie "market" than to plant wheat which will rust and not pay for harvesting?

We have contracted for the crop from a number of farms upon which only D 5 was raised and have a fine stock of cleaned seed to offer. $\$ 3.00$ per bu. Sacks extra.

\section{RYE}

Land which has been planted to wheat, oats or barley until it seems "run out" will often produce a crop of other grain because different grains require different plant foods and while a field may be deficient in the requirements of one crop it will produce other grain.

Rye matures faster than the other grains and for this reason is often planted to "clean up" a field. It ripens so early that most of the foul plants, such as mustard and wild oats, that grow from seed, will be harvested before their seed has shelled and not allowed to spread over the field.

There are two kinds of rye-one planted in the fall and one planted in the spring.

Prices on application.

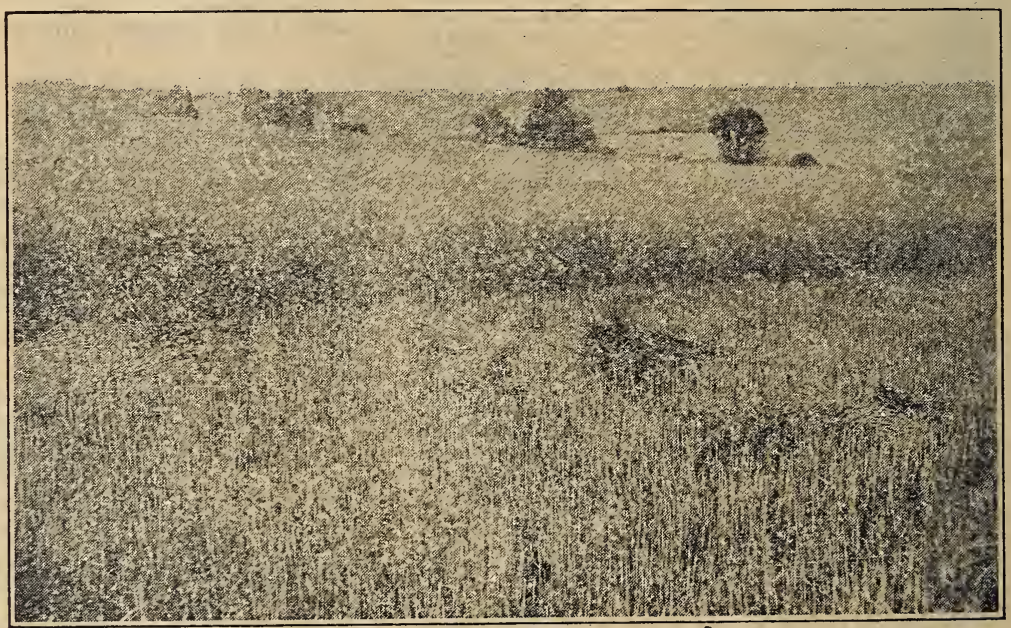

Field of $D 5$ Wheat. 


\section{MILLET}

The finest hay and heaviest yield is obtained by planting $1 / 2$ bushel per acre. For hay, millet should be planted late in the spring as the quick growth that comes with warm weather makes the best hay. We have, hanging in our office, a bunch of Southern Golden Millet planted June $7 \mathrm{th}$ and pulled July 29 th, the stems being 48 inches long, covered with broad leaves and head just showing. The millet should be cut for hay as soon as the heads are formed.

All of our hay millet seed is Kansas grown as we have found that home grown seed does not produce a large crop of foliage but brings seed upon short stems.

Common Millet. The good qualities of this millet are numerous and among them, it is drought resistant, will produce a fair crop on poor soil, is one of the earliest; stools freely and makes a very fine quality of hay. We look for a heavy demand for this seed so would urge early orders. Price, $\$ 2.25$ per bushel by freight or express at purchaser's expense. Sacks extra 65c.

Golden Millet. A rather new development of millet which is a decided improvement upon the old strains. Produces a heavy crop of broad thick leaves and is particularly desirable as fodder for cows. Price, \$2.75 per bushel, sacks extra, 65e each.

Siberian Millet. The old favorits. The hay is rather finer and longer than fro the Golden millet and farmers tell us it makes better feed for horses than any other variety. Price, \$2.50 per bushel, sacks extra, 65e.

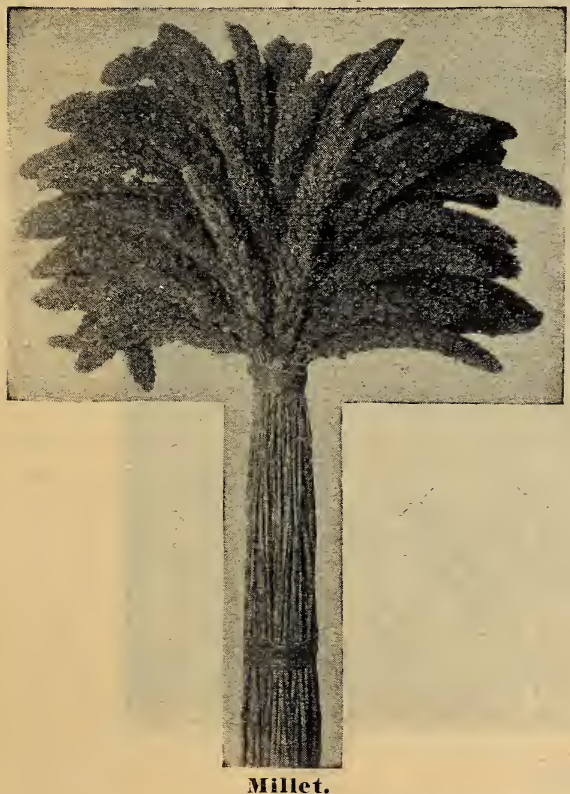

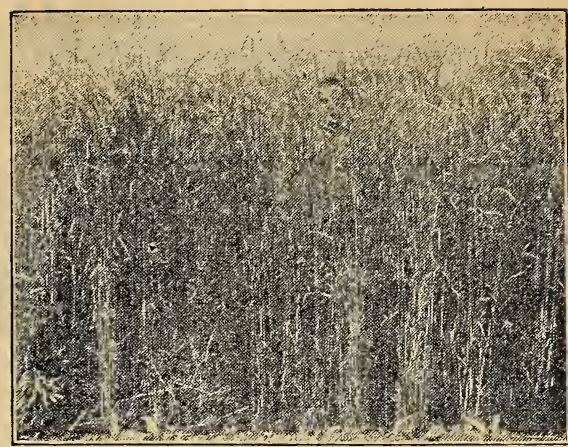

Rye.

Japanese Millet. This grows as much as ten feet tall and makes a wonderful crop. The seed being triangular and dark brown, does not resemble any other millet. The hay is coarser than the other millets but all stock will eat it clean. Write for price.

Besides being raised for hay, millet may be allowed to ripen seed which is threshed and used for feed. All of the prepared poultry feeds upon the market contain a large percentage of millet. Ground millet is as good feed for hogs or fatting cattle as corn.

We offer the two leading varieties of seed millets and the amount of feed you will obtain from a few acres of one of them will be a most agrceable surprise.

Early Fortune Millet. Produces a heavy crop of plump dark red seed. Many agriculturists plant this upon foul land and, as it ripens early, get the weed seed when the millet is cut. Price, \$2.75 per bushel, sacks extra, 65e each.

Broom Corn Millet. This does not grow so tall as other millets but the heads branch. Because the seed is such excellent hog feed, some seedsmen oall this "Hog Millet." Price," \$2.50 per bushel, sacks extra, 65e each.

Northern Seed Co., Valley City, N. D.

Kind Sirs: We have used your seeds for years and like them far the best of any we ever used before and am sending to you for a large order of seeds today. A well satisfied customer. Respectfully,

Pelican Rapids, Minn. Mrs. Norman Brock.

Northern Seed Co.; Valley City, N. D.

Gentlemen: I have used your seeds for several years past and have found them very satisfactory. Kindly fill enclosed order immediately and oblige.

Zohl, N. D. Respectfully, Mrs. Carl Hohman.

Northern Seed Co., Valley City, N. D.

Gentlemen: I have used your seed for soveral years past and have found them satisfactory. Kindly fill enclosed order immediately and oblige. Respectfully,

Coteau, N. Dak.

Prices Subject To Change Without Notice. 


\section{ALFALFA}

She highest praise any seedsman or enisiastic farmer ever offered for a forage ip is to say "it is good as alfalfa." But en put to the test, nothing that ever ne out of the ground equalled alfalfa, ler hay or pasture. When green, horses, tle, hogs or sheep will eat it rather than y growing grass or grain, while alfalfa $y$ will make more milk per ton than in fed to cows. Even chickens will eat alfa hay and lay more eggs thru winif fed a liberal amount of hay with the tin.

llfalfa should be sown upon ground ich has been plowed six or eight inches :p and the furrow thoroughly pulverized. ow in the fall or early spring then disc not take the crop off the oround the st year, but when plants are eight inches l, run a mowing machine set high as it 11 work over the field and let the cutgs lie for a mulch. Alfalfa should go o the winter with eight inches of growth ove ground beoause the crown which 'ms just under the surface of the ground 11 be damaged by freezing and thawing; sse chances can be avoided by having a avy mulch upon the field.

[wo crops of hay are cut any ordinary ison and the field will yield excellent sture early and late if not cut for hay.

Vorthern Brand. In offering this szed the trade, we have seven seasons exrience back of our statement that no tter alfalfa can be had anywhere at any ice. We have bought the seed from the ne fields for seven seasons and know

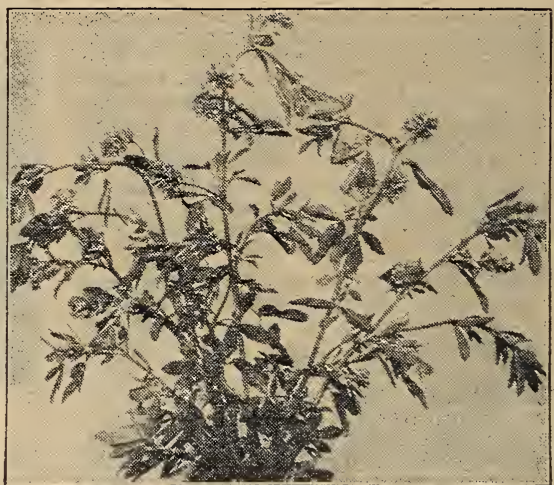

Alfalfa in Bloom.

that it is pure and goes to the trade $100 \%$ perfect with a germination test better than $90 \%$.

As a field of alfalfa is a permanent investment the first cost of seed is spread over many crops so the best will prove cheaper than an inferior seed at smaller first cost. Price, 1 pound $70 c$, postpaid, by freight or express at purchaser's expense $\$ 55.00$ per hundred, sacks extra, 650 each.

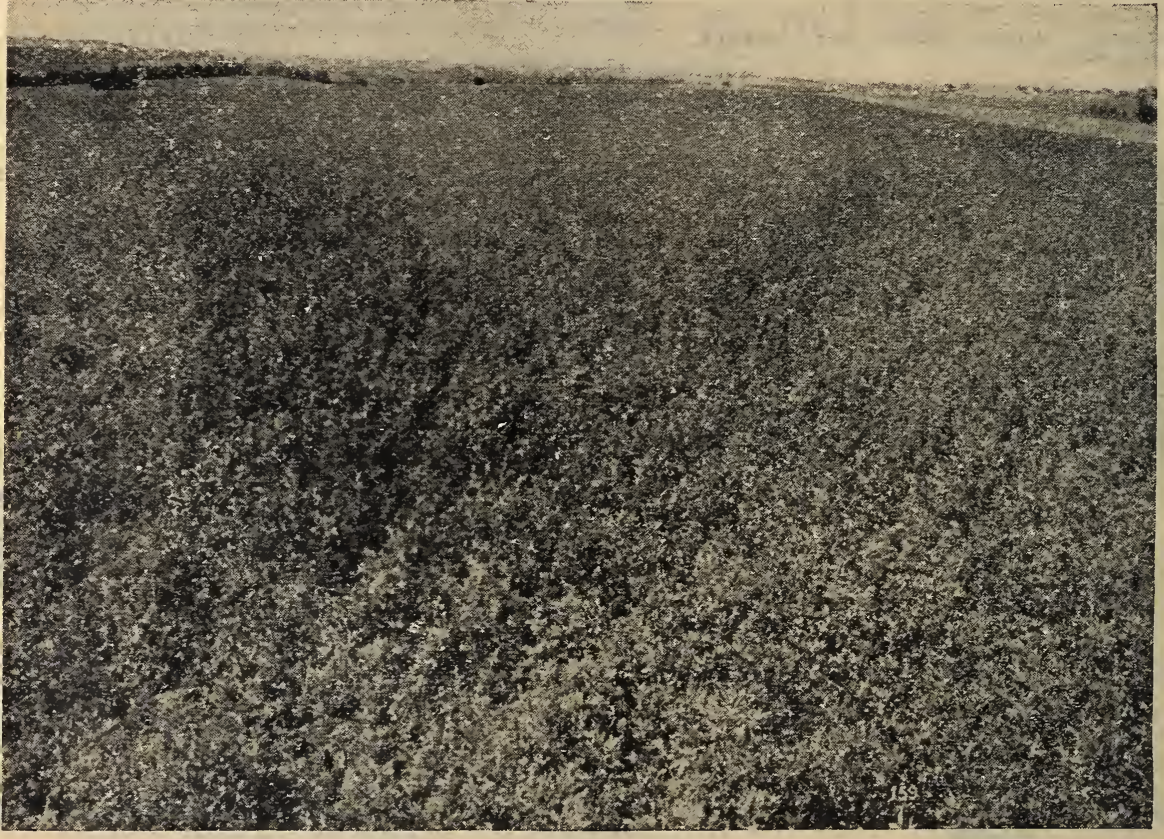

Northern Brand Alfalfa.

Prices Subject To Change Without Notice. 


\section{Early Blood Turnip Beets}

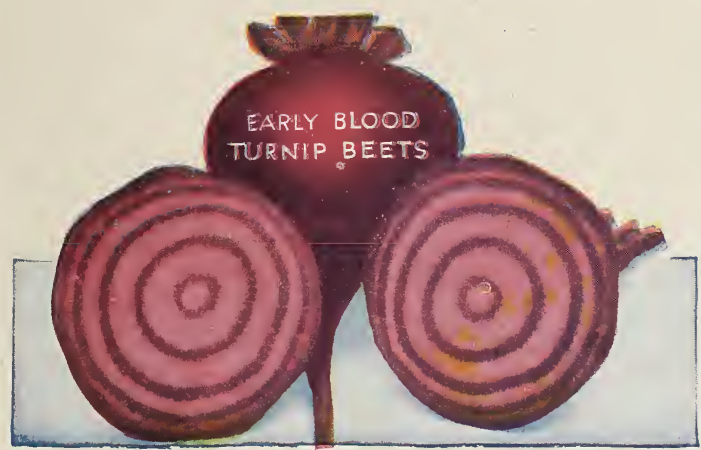

This is an early variety and a great favorite with the truckers on account of uniformity of size and symmetry of shape. It is finely grained, unsurpassed in quality, tenderness a n d sweetness. It continues to grow until late in the fall, attaining a large size as a winter beet. One sowing only is necessary to produce a crop for early summer marketing and a main crop for winter use.

\section{Danvers Half-Long Carrots}

No better to be found anywhere. All gardeners know the importance of securing the best seed to grow really fine crops. This can be relied upon as the best seed to be obtained at any price. It will yield twenty tons per acre. See page 7 .

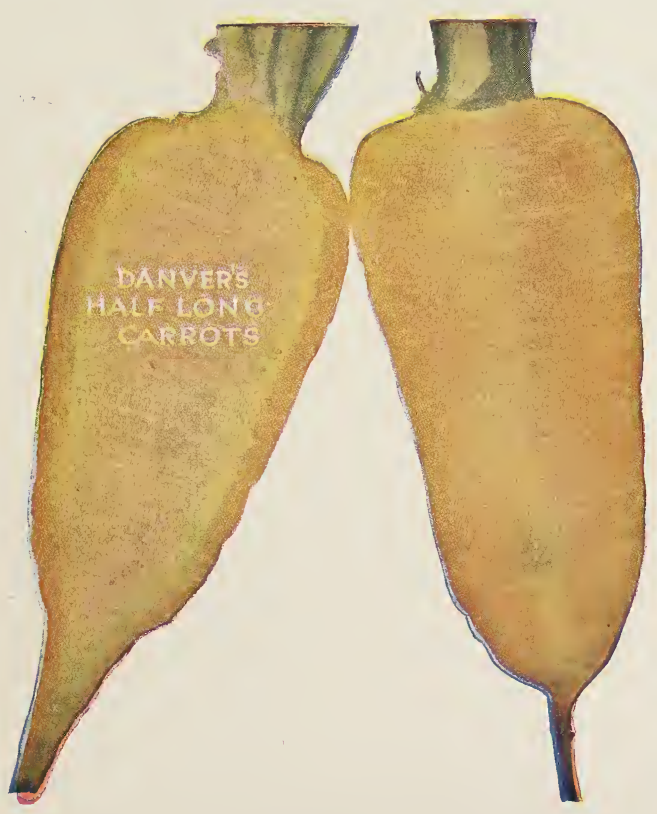




\section{Sweet Clover}

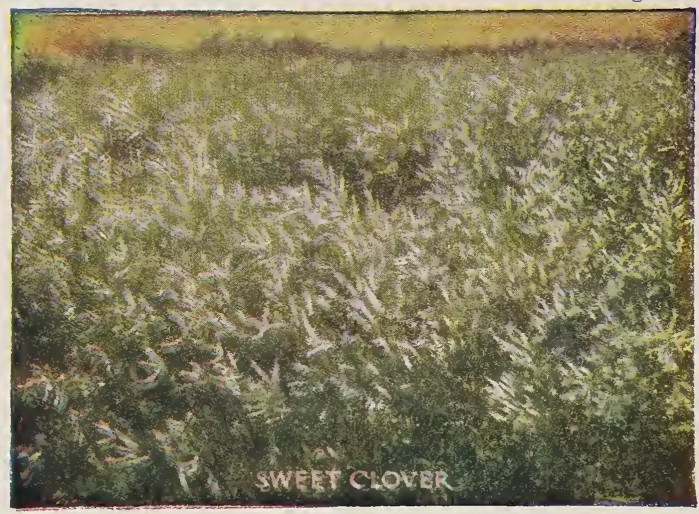

Sweet Clover is recognized as the greatest soil builder which we have. Each acre of sweet clover will add three or four times as much nitrogen to the farm, as will red clover.

It has other uses however, in addition to its soil building properties. Live stock eat the hay with relish after they have become accustomed to it, and if the clover is cut early when about two feet high, it has apparently the same feeding value as alfalfa. The sweet clover has been used very successfully for pasture purposes, both with sheep and hogs. It is possible to pasture all classes of stock on sweet clover, since there is no danger of bloating with it.

Contrary to common opinion, it is not at all difficult to get rid of sweet clover, as it is a biennial the same as is red clover.

\section{Early Amber Cane}

Dairy farmers say that Early Amber Cane is the most valuable fodder plant in existence for their use. It is of the very best quality, being sweet, nutritious and greedily eaten by cattle, horses, and hogs. Grown successfully in any part of the country, from Canada to Texas, and from the Atlantic to the Pacific. It is one of the best plants to withstand drouth and unfavorable weather and is therefore a comparatively sure crop.

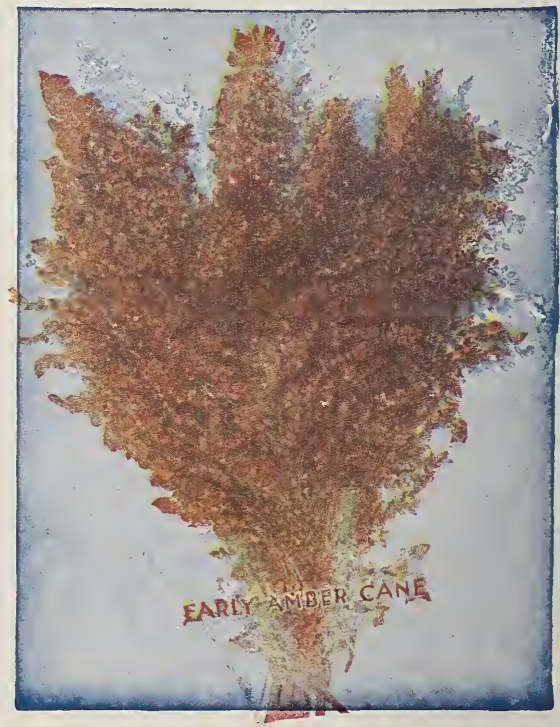




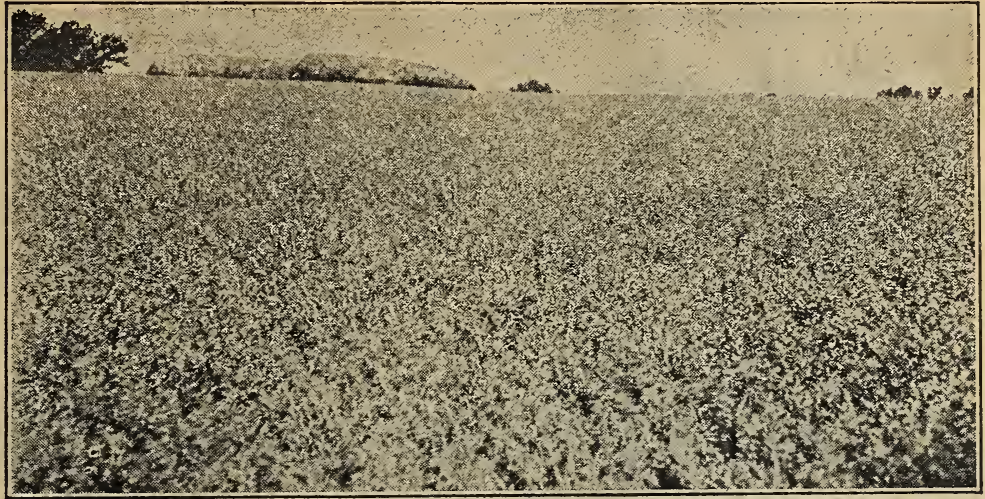

Field of Grimm Alfalfa.

(ienuiue Grimm. This is the variety often called "Everlasting" because of its ability to withstand adverse conditions. The authorities from the Agricultural College have examined a great many flelds over .e state and when they find a field of $r$ tuine Grimm free from foul seed or impurities, they issue to the owner of the field a certificate stating their findings. Our stock of Grimm comes from unly certified fields. Price, 1 pound $80 \mathrm{r}$, postpaid, by freight or express at purchaser's expense $\$ 70.00$ per hundred.

\section{SWEET CLOVER}

In a recent report the Department of Agriculture says "the ease with which the seed may be produced and the fact that waste land can be profitably utilized have caused extended investigation of the crop. The advantages of sweet clover, therefore, are becoming better known. Some surprising information has come to light considering the fact that less than ten years ago sweet clover was classed as a weed. It now is known to have its uses, particularly in dry climates where it is employed extensively in preparing the soil for alfalfa and is grown as hay crop in some sections.

No other crop equals it for results on worn out lands. It thrives on a thin, gravelly soil, sufficient water being provided. Its humus demands are less than nearly any other crop while its humus contribution is heavy. This latter characteristic makes it ideal in grain rotation,

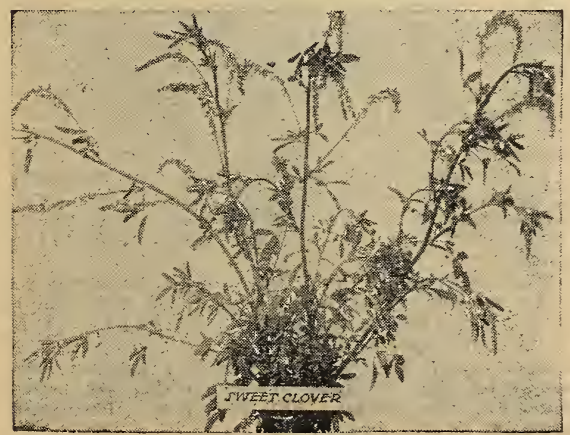

for by taking seed crop the second season, two harvests are secured from one cultivation.

A two year rotation plan is also used, in connection with sheop. The pastures are moved each year to the new seeding and another crop sowed behind the sheep. The combined benefit to the land of the sweet clover and the sheep has a niarked effect in increasing grain yields an ine pastures are found equal to carryine ten ewos and their lambs to the aere when the clover is permitted to get a fair stari. The foregoing was written about cinditions at Wheatland, Wyoming. The soil there is lighter and the rainfall less than the average for North Dakota. Here in Barnes county the past season yields of seed that sold for $\$ 90.00$ per acre were $(1)$ tained from a great many fields, most ot these being the second crop after a cutting of hay had been taken from tile ground. Two crops of hay and a gene:ous growth left for winter protection is the report from the flelds where no seed crop was matured. The hay should be cu: soon as the blooms appear and the hay cured in shocks; then put into stack or mow and cattle or horses will leave wild hay millet or corn fodder for sweet clover.

If there is a "waste corner" upon your farms, plant sweet clover there and it will yield more hay or value in seed than the same number of acres planted to any grain crop.

At Bismarck, N. Dak., June 12th. last, the writer saw gweet clover as high as a man's waist and so thick it was hard to walk thru it and across the street were lawns upon which the growth of grass was so slow that a mower had not been used upon them yet that season. Price, 1 pound 35c, postpaid, by freight or express at purchaser's expense $\$ 30.00$ per hundred pounds. 


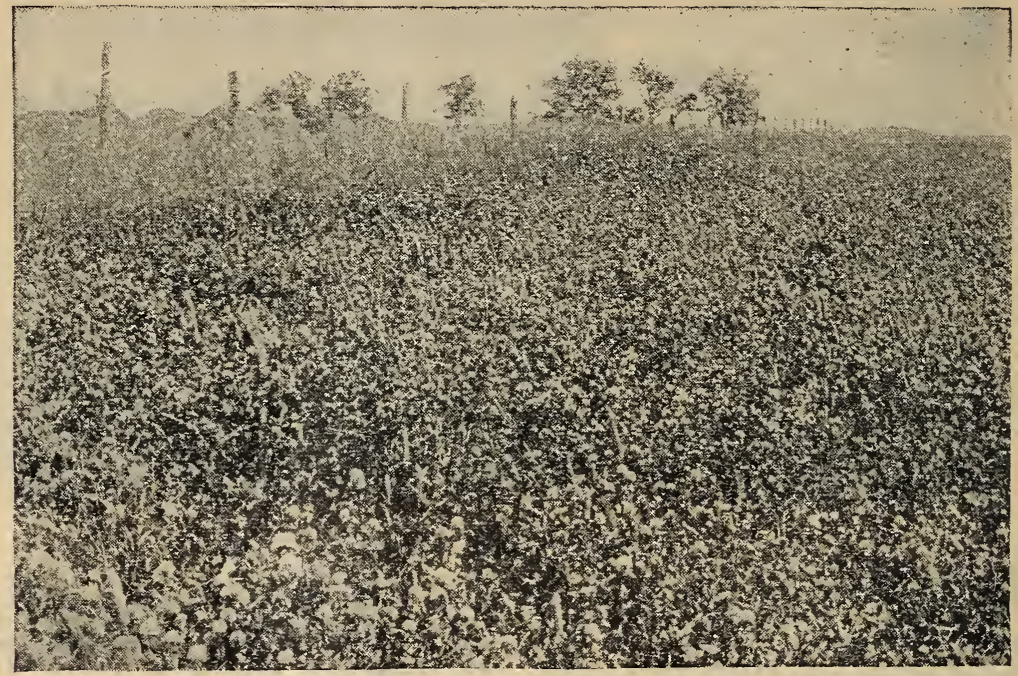

Medium Red Clover.

\section{SLENDER WHEAT GRASS}

This is also called "Western Rye Grass." It produces a finer stem and more leaves than any of the cultivated grasses. It stands dry weather and freezing better than timothy and produces a heavy crop of the finest hay when other grasses fail. Use 12 to 15 pounds of seed per acre and plant upon the same land and same time as you would plant to raise wheat. Many farmers have been afraid of Bromus Inermus because it was considered hard to kill. Slender wheat grass makes better hay, will not spread so much and the root system is more easily killed than Bromus. Price, $\$ 20$ per hundred pounds, by freight or express at purchaser's expense.

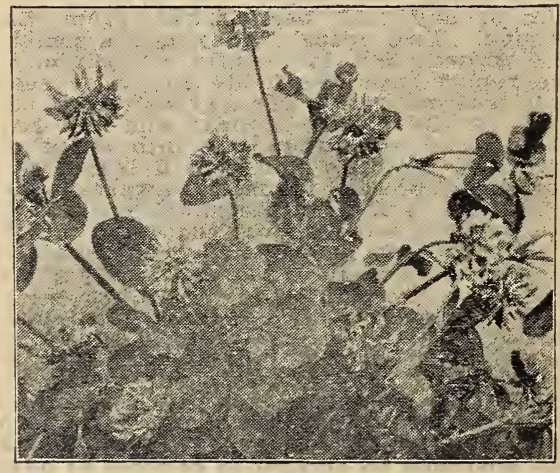

Alsike Clover.

\section{MEDIUM RED CLOVER}

This is the main hay and pasture crop of Iowa and Illinois and will grow here if the land is properly prepared. Planting a little seed each year for a number of years, as described under Alsike clover, is the best method of starting Medium Red Clover and the returns will repay the effort. Price, 1 pound roc, postpaid, by freight or express at purchaser's expense $\$ 55.00$ per hundred pounds, sacks extra, 65e each.

\section{ALSIKE CLOVER}

Alsike is exceptionally leafy and has thin stems making very fine hay, the fee ing value being almost equal to alfalfa. It grows two or three feet high and bears a pink and white blossom which appears in July or August.

This clover does best upon moist, loamy soil, but will do well upon heavy clay ground. It is very hardy and will not winter kill. The best "catch" is usually obtained by sowing with grain crop and leaving the stubble fairly long for protection the first winter. The Minnesota Experiment Station by experiments over a number of years, have shown that the increase of grain yields upon plots in which clover was sown with the grain seed, much more than paid for the clover seed and extra labor.

Alsike should be cut for hay as soon as it is in full bloom. If wanted for seed, cut when two-thirds of heads are ripe. It is one of the best honey producing plants grown. Price of seed, 1 pound 60e, postpaid, by freight or express at purchaser's expense $\$ 50.00$ per hundred pounds, sacks extra, 65e each.

Prices Subject To Change Without Notice. 


\section{BROMUS INERMUS}

Nothing grown in the Northwest makes a pasture as good as this grass. Plant early in the spring and cover the seed with one-half inch of soil-use 10 to 14 pounds of seed per acre. You will have a pasture second to none that can be grown. We have kept in touch with the North Dakota Agricultural College and know from their examinations what fields and farms are free from quack grass and we buy seed only from quack free fields so we are positive that you take no chance of getting quack grass in seed you buy from us. Price, \$30.00 per hundred pounds by freight or express at purchaser's expense.

\section{SUDAN GRASS}

This is a sorghum which grows rather larger than amber cane. Being a southern plant it grows best in hot weather and should be seeded late in the spring. Cut it just before the heads come out, either with the mower or binder. As there is much sap in the leaves and stalks, the hay must be well curel before stacking. Eight tons of sweet, wholesome fodder are often raised from a single acre of this crop.

Plant 15 to 25 pounds of seed per acre if broadcast or six pounds in rows to be cultivated like corn. Price, 1 pound 30c, postpaid, by freight or express at purchaser's expense $\$ 16.00$ per hundred pounds.

\section{KENTUCKY BLUE GRASS}

This is the pasture which raised the best horses the country even knew. Its name suggests a warm climate but it grows and thrives in the Northwest. Most of the lawns in this section that have a good

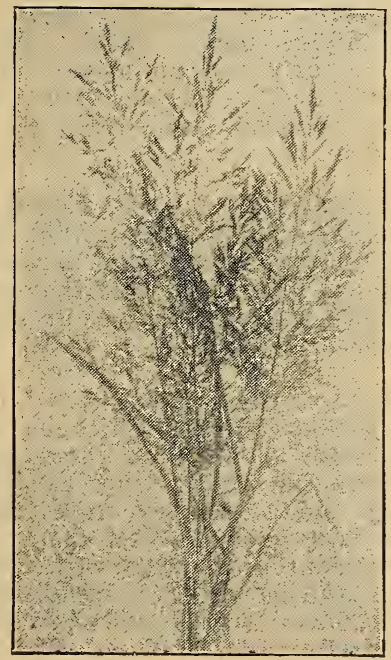

Red Top.

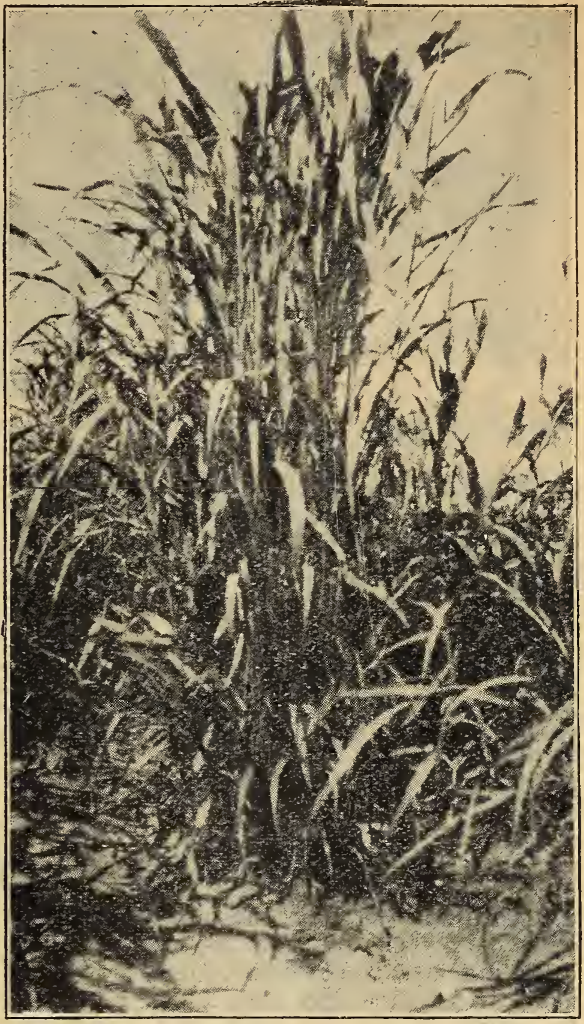

Sudan Grass.

growth of grass are Kentucky Blue Grass and the lawns survive the winter and get a hoavier sod as the years go by. If blue grass in a fleld is started as a good lawn must be started, it will last for many years.

Plant 10 pounds per acre upon well pulverized soil and leave the first season's growth upon the ground. After that do not pasture it too late in the fall and you will have blue grass as long as you wish it. Price, per pound 40c, postpaid, by freight or express at purchaser's expense $\$ 35.00$ per hundred pounds, sacks extra, 65e each.

\section{RED TOP}

This is adapted to low rich lands. It will grow where all ordinary grass is killed by spring floods. It grows two feet or more high and makes excellent hay and can be grown upon land which usually will not produce a crop. Plant 8 to 10 pounds per acre. Price, ver pound 30e, postpaid, by freight or express at purchaser's expense \$25.00 per hunilred pounds.

Prices Subject To Change Without Notice. 


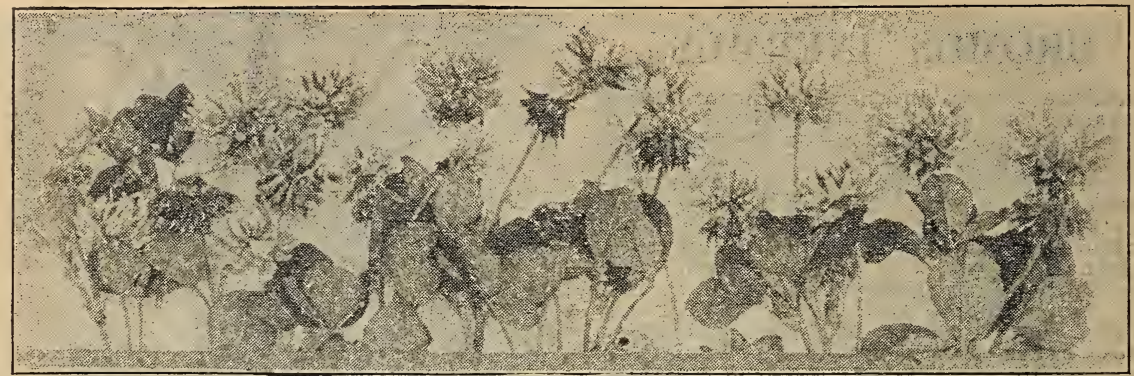

White Clover.

\section{BUCKWHEAT}

Plant four or five pecks per acre at the same season you would plant flax.

Buckwheat is grown for the seed crop, for hay and makes a wonderful fertilizer if planted upon land to be summer fallowed and turned under green. For hay cut when in bloom and handled as other hay.

Silver Hull. This variety is most grown and has proved to be the best for our climate and soll conditions. The grain is light grey in color and the hull very thin. Millers prefer it as it makes a lighter colored flour and shows less waste than common varieties. It yields up to 50 bushels per acre. Write for price.

\section{WHITE DUTCH CLOVER}

This variety of clover will succeed upon almost any soil under any conditions but does best upon fairly moist soil and wet seasons. It does not grow very tall but starts quickly and survives many unfavorable conditions; this makes it desirable for pasture or hay mixtures because it protects the slower growing grasses while they are getting started. But the follage of the clover is very tender and stock will nibble the ground bare to get it all.

Three pounds each of White Dutch Clover, Kentucky Blue Grass and Red Top make an excellent pasture mixture. Price, per pound 75e, postpaid, by freisht or express at purchaser's expense 65 e per pound.

\section{POULTRY FEED}

At no time during the past year have eggs been less than $30 \mathrm{c}$ per dozen in the iocal markets. November first they were 60c and grocers say that fresh eggs will be worth 75 or 80 cents per dozen for the greater part of the winter. A fair sized hen or rooster will cost one dollar here now. We recite these things to im. press upon you that a large amount of money will be realized from a flock of chickens that are properly handled.

Through the summer months, when hens can run loose, upon the average firm they require but little care or feed and the "town hen" will do well with little attention. But when winter comes, unless they can be kept warm and fed it will not pay to have them around. During winter months, the farm hens get screenings from threshing and "something good for nothing but hen feed" while the "town hen" gets whatever the owner finds handiest to feed. The fact that proper feed and shelter is not provided makes eggs scarce and higher priced in winter than in summer. The wise poultry man will have his hens laying in the cold weather and get the high price for his eggs.

We have found that no one grain makes the correct feed for poultry but a combination of grains fed to hens properly housed will make them lay as many eggs in cold weather as warm. And we offer two poultry feeds which are balanced rations each the best for its purpose that can be had at any price.

\section{Reliable Hen Feed}

A mixture of cracked corn, kaffir, wheat, millet, barley, oats, and sunf́lower; no dirt and no waste. This is the correct feed for laying hens. Price, $\$ 4.00$ per hundred, sacks free, F. O. B., Valley, City.

\section{Challenge Chick Feed}

Corn, wheat, and other grains broken fine enough for little chicks to eat. The little chicks will clean this feed up and keep growing all the time. Price, $\$ 4.25$ per hundred, sacks free, F. O. B., Valley City.

Neither of these feeds contain any gravel, grit or shell. Chickens should have mineral food but it should not be mixed with the grain. And as grit and shell are much cheaper than grains a mixture that does contain them should not be compared, in price, with mixtures containing these cheaper ingredients.

We can furnish grit and shell at $\$ 1.75$ per hundred, F. O. B., Valley City at the market November first, but the prices change often and if you need grit or shell, please write for prices. 
While America is trying to feed the world, rats annually destroy $\$ 200,000,000$ worth of food stuffs in the United States. Now, as well as during the war, it is the duty of every person to conserve food stuffs. In this connection we offer to the public

\section{RAT CORN}

The recognized Rat Exterminator. The only known Rat Destroyer that may be used with safety.

\section{IT IS HARMLESS TO HUMAN BEINGS \\ IT IS NOT A DEADLY POISON \\ IT LEAVES NO ODOR}

SAFE

SANE

SANITARY

If you cannot do anything else, you can kill rats. Rat corn is put up in boxes selling at $\$ 1.00,50$ cents, and 25 cents. Full directions upon each box.

A medium sized box, costing 50 cents, will prepare enough bait to exterminate all of the rats around an ordinary set of buildings.

\section{GARDEN SPRAYERS}

Consider the things a sprayer will do: Put poison upon potato vines; spray chicken houses, roosts and nests; put fly killer upon horses or cattle; treat grain with formaldehyde; spray bushes or trees.

We offer three sizes of sprayers, each an exceptional value for the price asked.

MIDGET-A small sprayer for house use, will handle disinfectants, bug-poisons, etc., etc. Length over all, 14 inches. Made of heavy tin. Holds one pint. Price $30 \mathrm{c}$; postpaid.

NEW MISTY
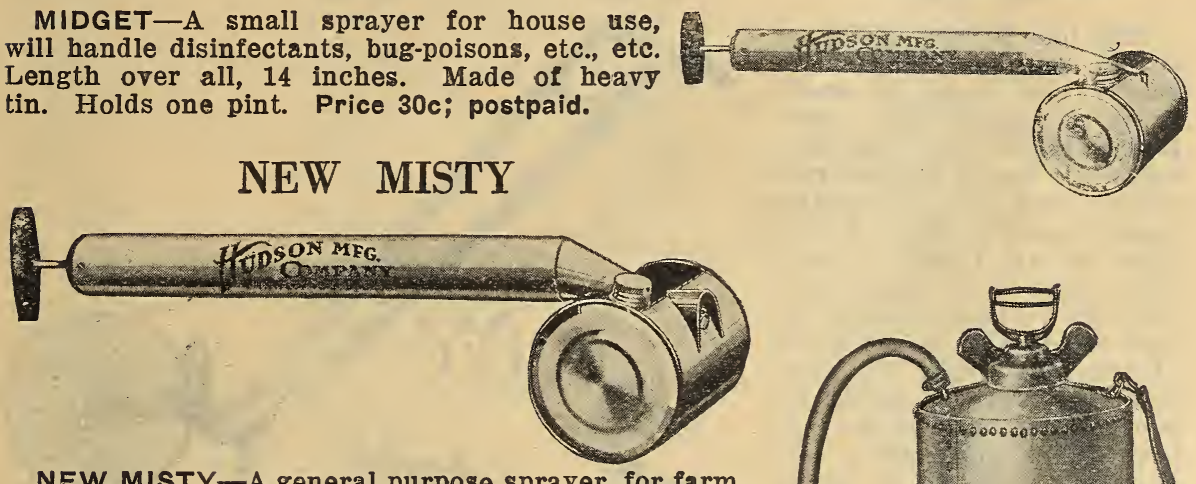

NEW MISTY-A general purpose sprayer, for farm, stable or garden uses. Handles fly-oils, bug-poisons and disinfectants. Has a large poweriul pump. Lock seamed can. Made of heavy tin. Tank $4 \times 41 / 2$ inches. Length over all 24 inches. Holds one quart. Price $60 c ;$ postpaid.

\section{PERFECTION}

PERFECTION-For spraying, disinfecting or whitewashing, on plants, bushes, vines, etc. Made of heavy metal, with few parts, strong in construction, powerful in action. Pump has bronze ball valve and is fastened to the top of the tank with heavy threads. Tank $71 / 2$ by 20 inches, lock seamed with 26 rivets. Hose attached with clamps. Furnished with automatic shut-off nozzels which will handle whitewash and thin liquids without change of parts. Made of Galvanized Steel or Brass. Weight packed 12 pounds. Galvanized-Price $\$ 6.50$ by freight or express.

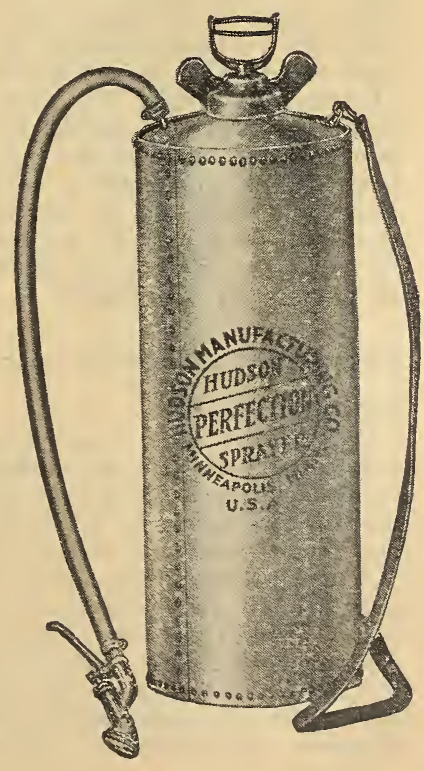




\section{GARDEN TOOLS}

CULTIVATORS, WHEEL HOES, DRILLS AND HILL SEEDERS

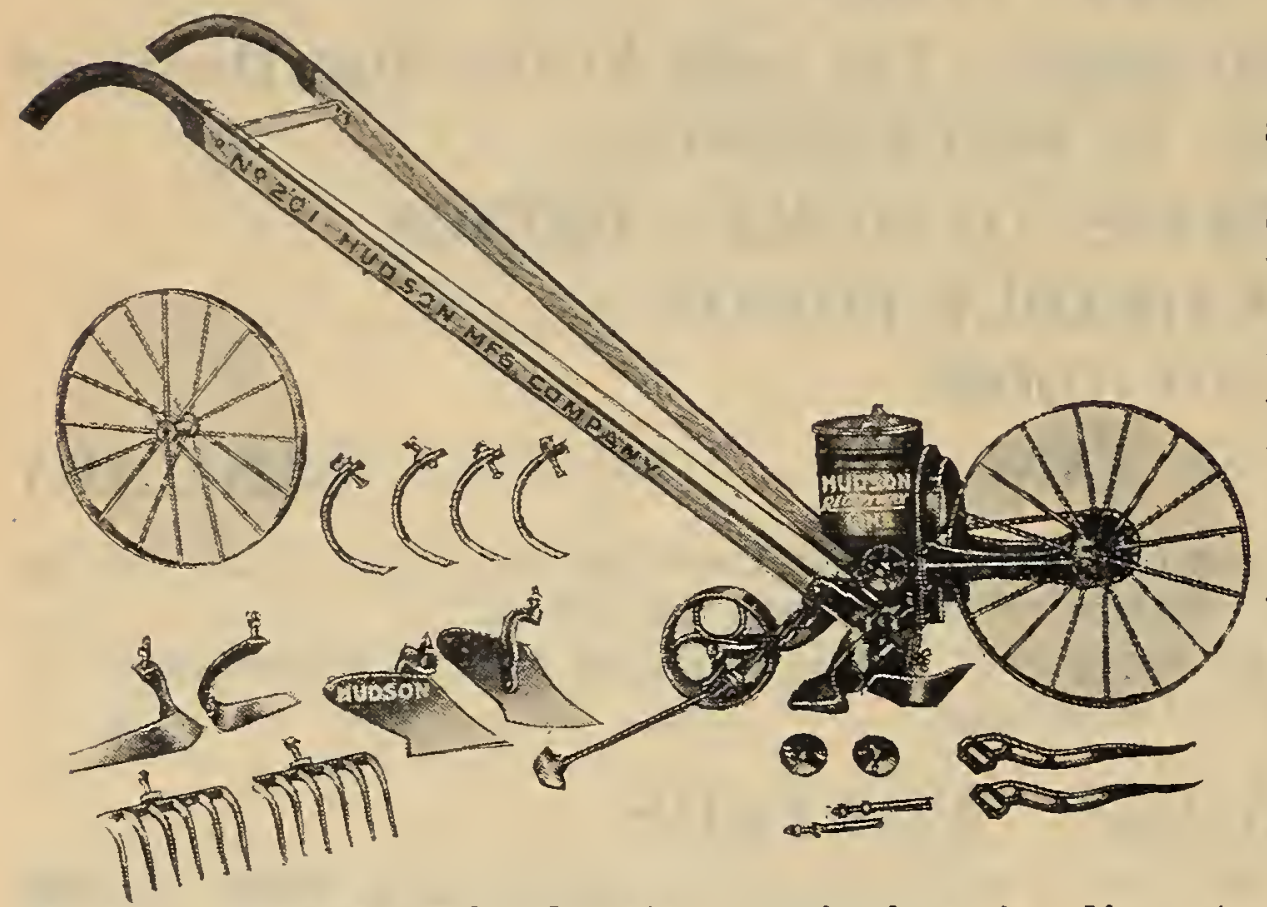

No. 201

A combination garden seoder and cultivator with complete equipment. It can be quickly changed to a double or single wheel cultivator, or to a seeder only. As a seeder it can be ar. ranged for either hill or drill work. It has a positive rotary force feed. The hill spacer is the simplest known and is quickly set for hills $4,6,8,12$ or 24 inches apart. The flow of seed may be stopped instantly by pulling a string. It is adjust. able for depths up to two inches. All metal parts are of steel and maleable iron, oak handles, bent patterns, adjustable to suit the tallest persuns; wheels sixteen inches in diameter. No. 201 combination seeder complete as shown, weight 55 pounds. Price $\$ 19.50$, F. O. B. Valley City, N. D.

\section{No. 216}

This tool is very useful for anyone who has a garden, no matter how large or small. It is equipped with hoes, plows, rakes and cultivator teeth. It has a sixteen inch wheel and an adjustable frame, making the tool suit. able for all kinds of work. The frame is so constructed that the various attachments may be adjusted to any width of row. By using this cultivator the work of caring for your garden can be done in less than one-quarter the time and will do it better than can be done with a common hoe. Weight, packed, 28 pounds. Price $\$ 10.50, F .0$.

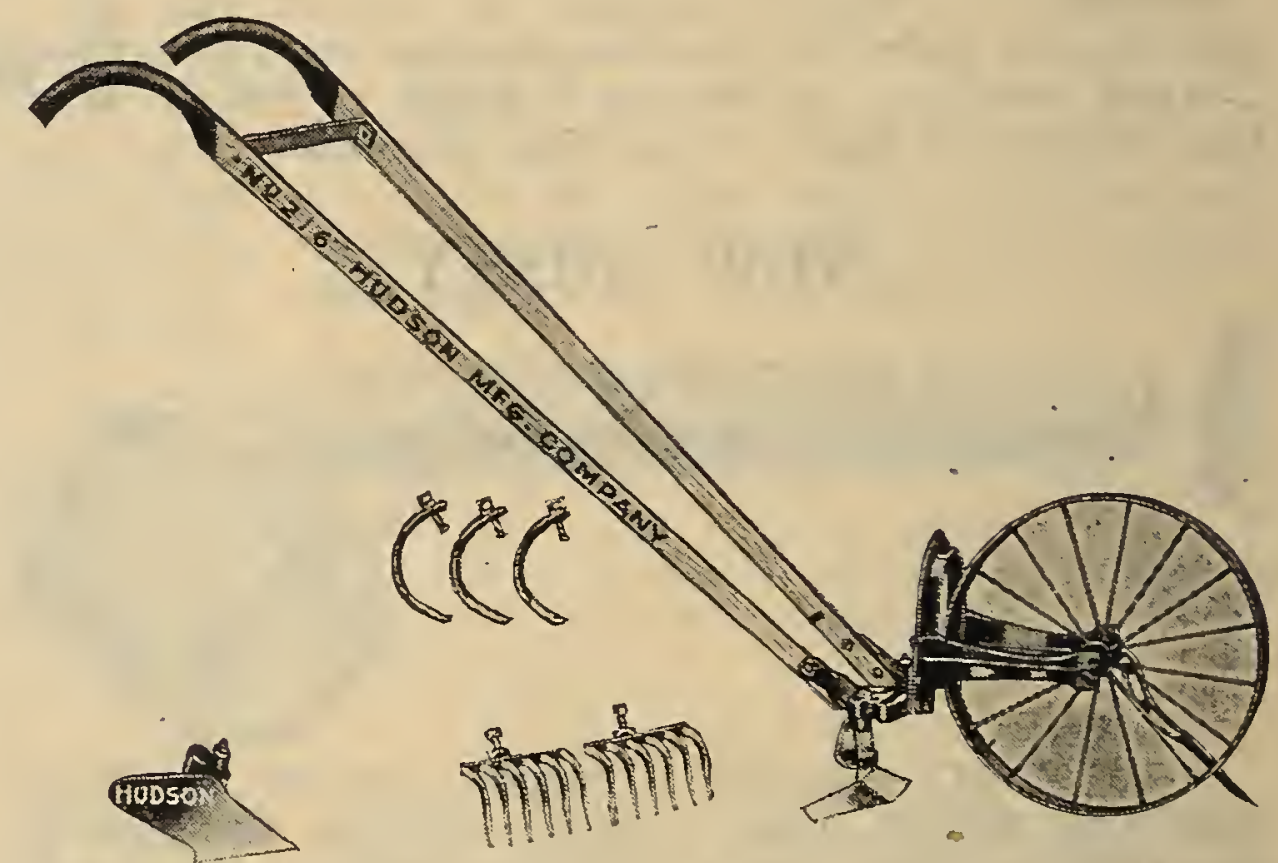

B. Valley City, N. D.
Northern Seed Co.

Gentlemen: We received your catalog today and forthwith got busy and selected what we needed for our garden. We got nearly all our seed from you last year and found them entirely satisfactory without exception. The onions (Prizetaker) grew to be the largest we ever raised, many measuring four inches across and were very uniform. Wife sold over $\$ 80$ worth of vegetables and we have an abundance for our own use till the new stuff is ready. Please find order and check en- closed. Thanking you in advance, we remain

Mr. and Mrs. Harry Bultema.

Wimbledon, N. D.

Northern Seed Co., Valley City, N. D.

I find your seed stock is about as well acclimated as any I can get. Have been offered stock at a nearer point but at a higher price and I believe your stock is as good.

John A. Grue. 


\section{FOREIGN NAMES FOR VEGETABLES AND HERBS \\ ENGLISH \\ GERMAN \\ DANISH- \\ POLISH \\ NORWEGIAN}

Anise ...........Anis, Gruner Anis.. Anis ............. Anyz

Asparagus ..........Spargel ..........Asparges .........Szaparag

Balm ............ Citronen-Melisse ...Balsamurt ........Balsam

Basil ...........Baslilikum ........Basilikum .......Barylia

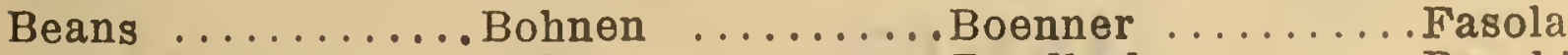

Beet ..........Rube ...........Roedbede ........Buraki

Borage ...........Borestsch .........Barago ..........Boraz

Cabbage .........Kopfkohl, Kraut ...Kovedkaal ........Kapusta

Caraway .........Feld-Kummel ......Karve ..........Kminek

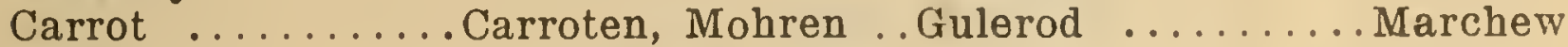

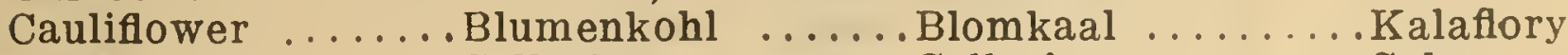

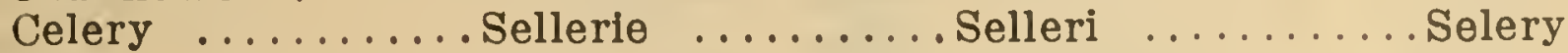

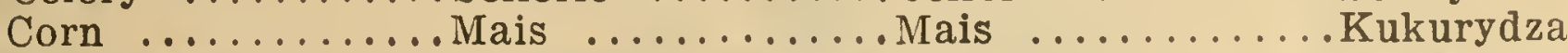

Cucumber ........Gurken ............. Agurk .......... Ogorek

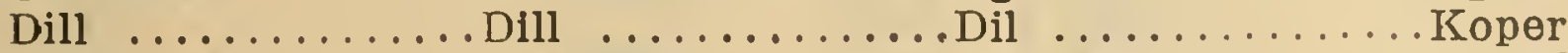

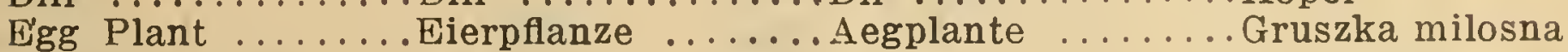

Endive, Curled ..... Endievien ........Endivie ........Endywia

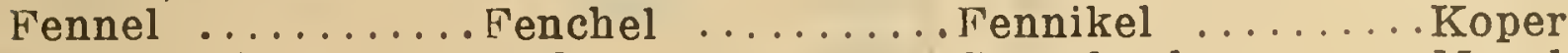

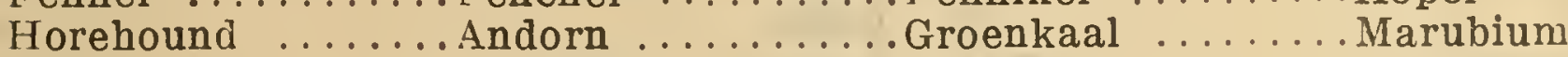

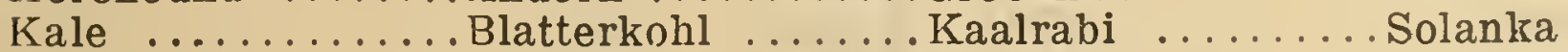

Kohl Rabi ........Knollkohl ........Lavendel ........Kalarepa

Lavender ......... Lavendel .........Purre ...........Lawenda

Leek ............ Porree, Lauch ..... Salat ...........Pory

Lettuce ......... Lattich, Kopfsalat .. Merian .......... Salata

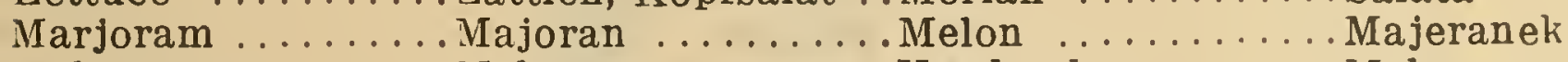

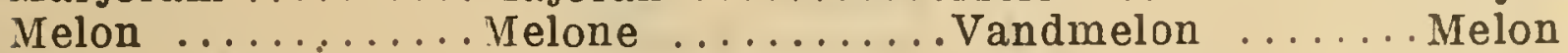

Melon, Water .....Wasser-Melone .....Blomkarse .......Melon, wodny

Nasturtium ...... Kaupciner Kresse ..Hibiskus ......... Nasturcya

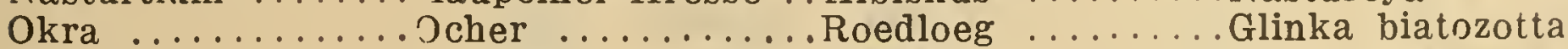

Onion .......... Zwiebel .........Persille ......... Celuga

Parsley .........Petersilie $\ldots . . .$. Pastinak ........Pietruszka

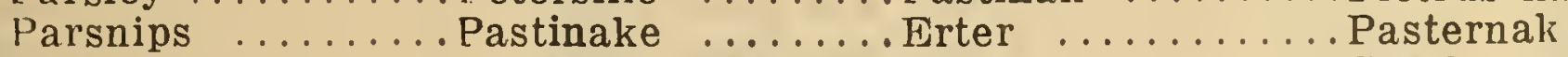

Peas ...........Erbsen .................. Gpansk Peber

Pepper .........Pfeffer ........... Graeskar ........Pierprz

Pumpkin .........Melonen-Kurbiss .. Reddik ..........Bania

Radish .........Radies .........Rosmarin .......Rzodkiew

Rosemary ......Rosmarin .......Roe ...........Rozmaryn

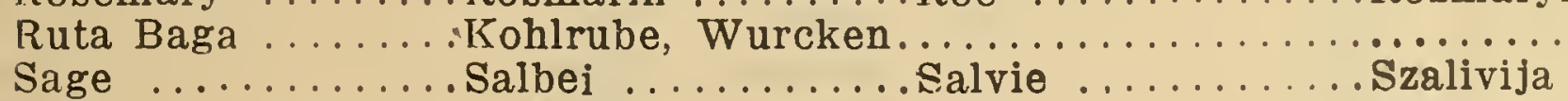

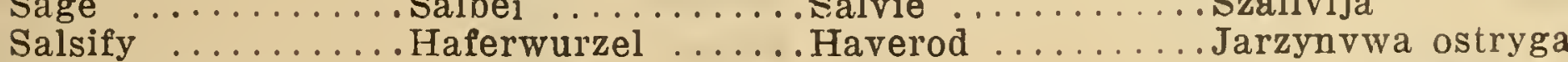

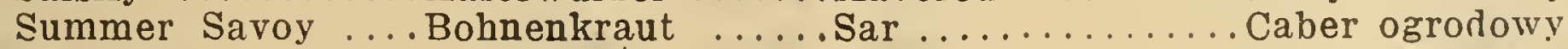

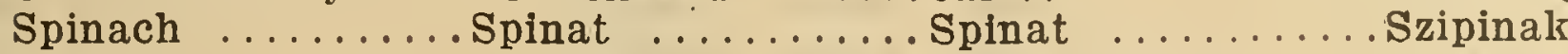

Squash ..........Kurbiss ..........Squash-graeskar ...Miekurz

Swiss Chard ........Beisskohl ........Blad bede

Thyme $\ldots \ldots \ldots$. Thymian .......... Timian

Tomato ................... Tomat

Turnip .........Weisse-Rube ..... Turnips

Macierzanka

Pomidor

Rzepa, brukiew

Northern Seed Co., Valley City, N. D.

I planted a lalge garden last year from your Valley City seed and think they can't be beat.

Sheyenne, N. D

Northern Seed Co., Valley City, N. D.

Dear Sirs: I will take the pleasure to let you know all the garden seed I got from you last year was fine, especially the Red Globe Onions and the Golden Tankald Mangle sure was fine. I am sending again for the same. Hoping you have some for me. Yours very truly.

Mott. N. $n$.

Phllin Schmint
Northern Seed Co.

Please send me your new catalog. I did live at Charleston, N. Dak., but have moved to Montana and did not send last year for your seeds and did not raise anything. So will send again this year as yours wero the best seeds I ever used and my neighbors are thinking of trying your seed this year as they had trouble with their seed not coming up. Please send catalog to the ten names I am sending and oblige.

Brandenberg, Mont.

Mrs. Jess Colts

From your Aster seed last year I had the largest and lovllest Asters I ever sam. They were grand. Mrs. A. C. Grell. 


\section{INDEX}

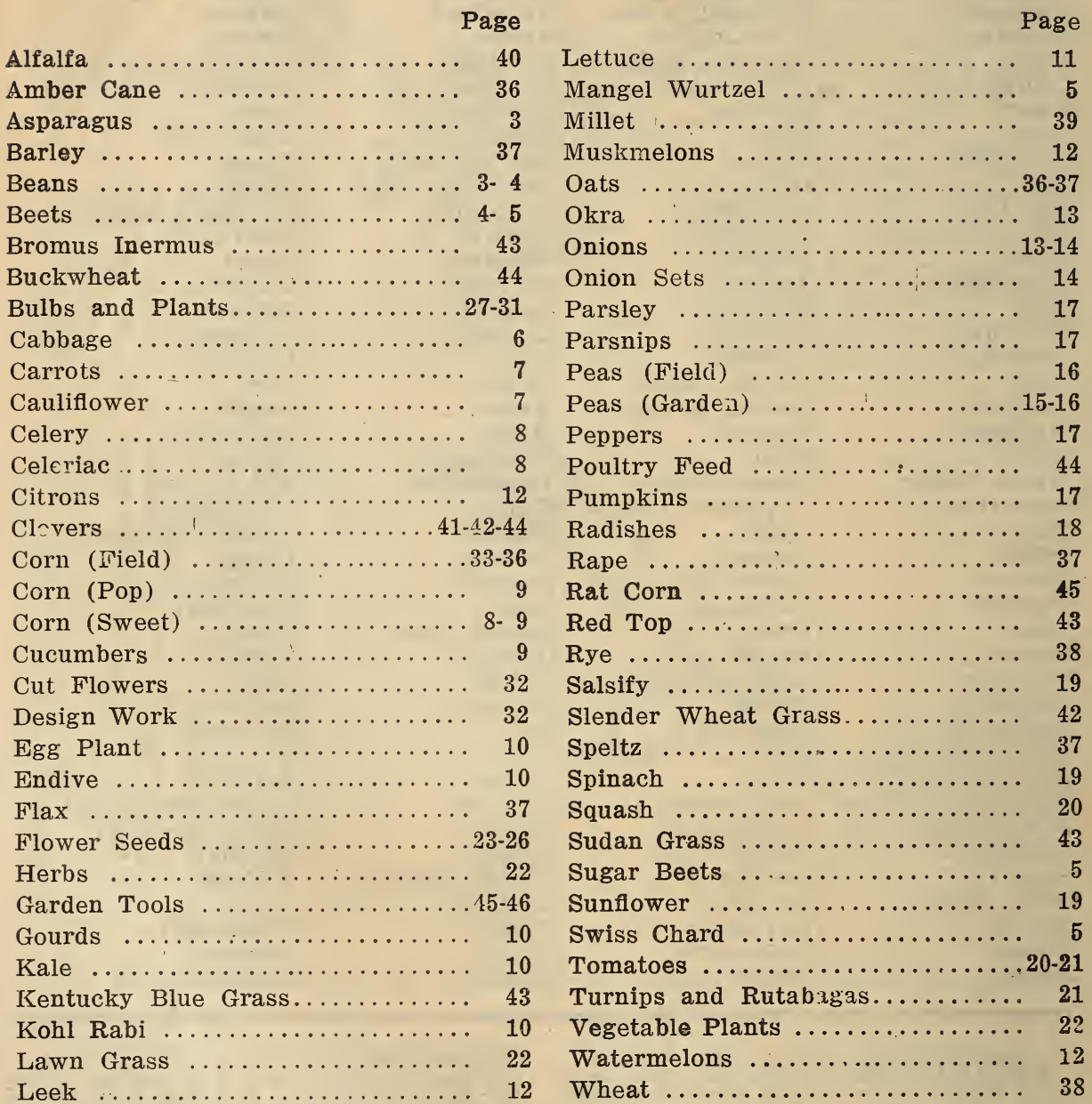




\section{ORBDER SHEFF F FR \\ "THE SEED YOU NEED"}

Garden, Flower and Field Seeds-Plants and Bulbs

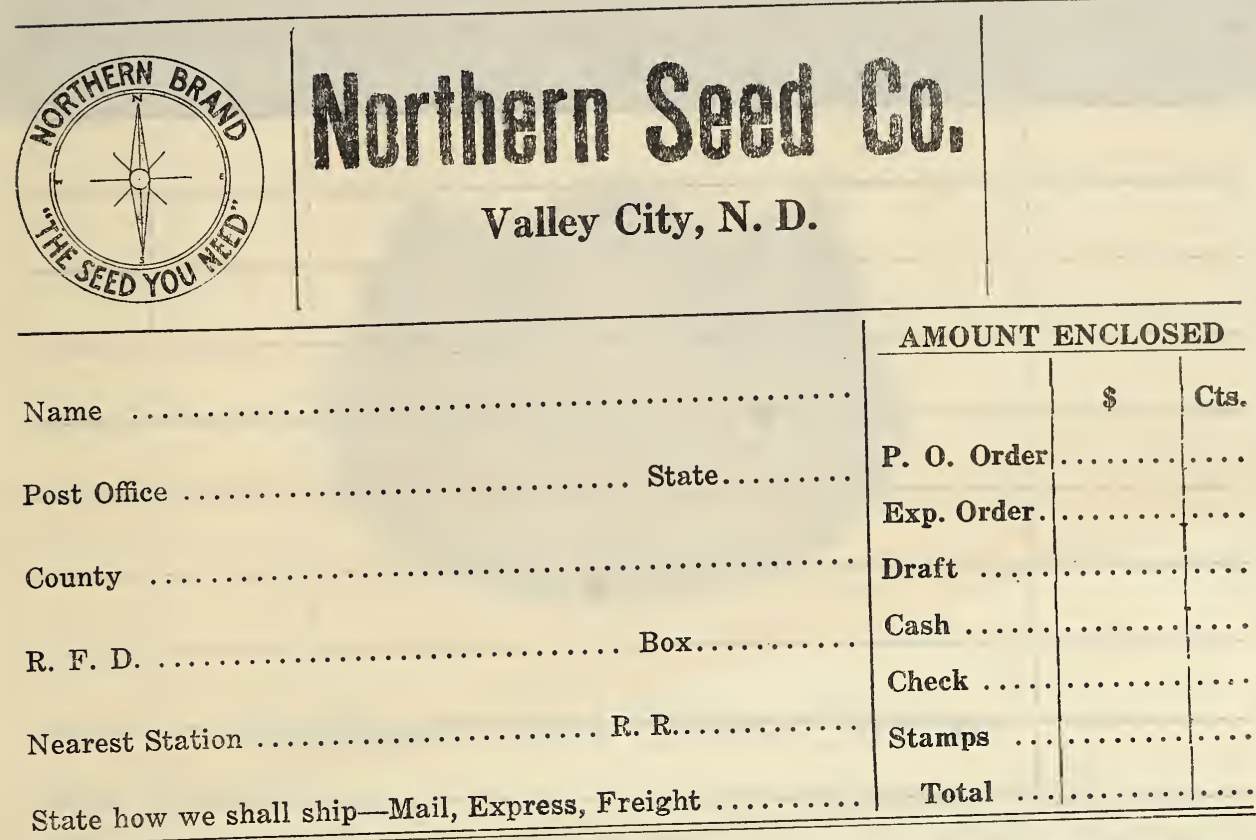
It is mutually agreed and understood that any seeds ordered of us may be returned upon receipt if not satisfactory, and money paid for them was they depend on so many not and can not in any way warrant the stand or the crop, NORTHERN SEED CO. conditions beyond our control.

\begin{tabular}{l|l|ll|l}
\hline Quantity & ARTICLES WANTED & $\mid$ & $\$$ & Cts. \\
\hline 1 & & & \\
\hline 1 & & 1 & 1
\end{tabular}

\section{NORTHERN SEED CO.,}

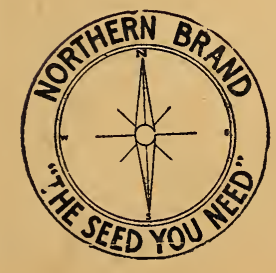

\section{VALLEY CITY,}

NO. DAK.

\begin{tabular}{l|l|l}
1 & 1 & $\dagger$ \\
\hline 1 & 1 & $\mid$ \\
\hline 1 & Amount Forwarded & $\mid$
\end{tabular}




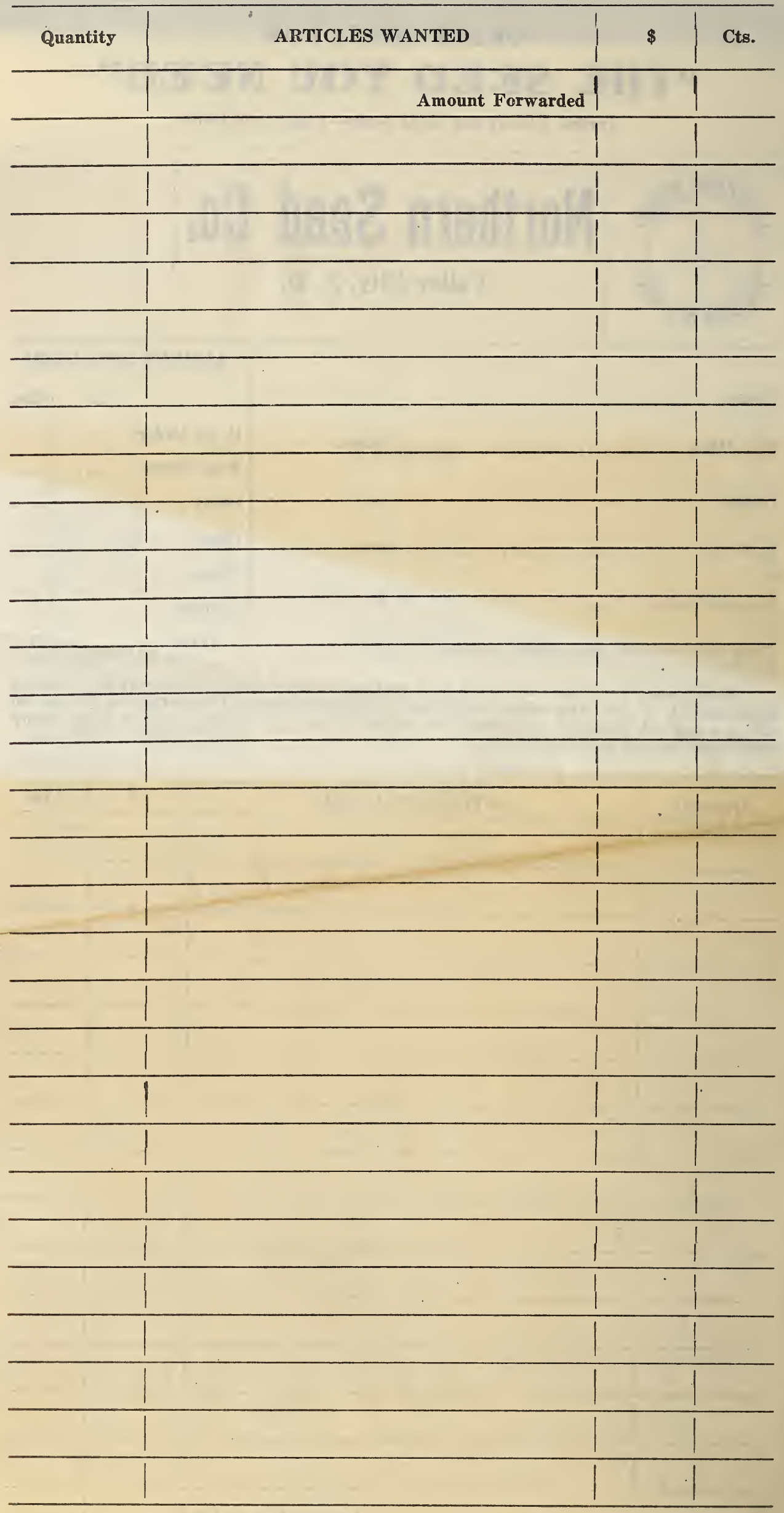

For the names and addresses of five friends who use seeds we will include with your order any two $5 \mathrm{c}$ packages or one $10 \mathrm{c}$ package you may choose. 


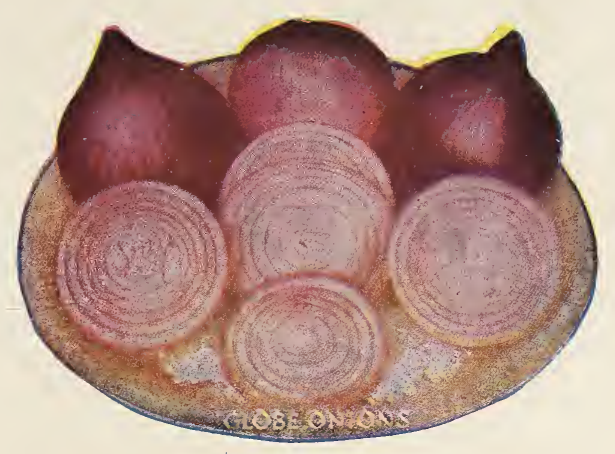

\section{Southport Red Globe Onions}

This splendid variety is. warthy. of general cultivation. Grows to a large size, skin of a deep red, flesh fine grained, mild and tender. They require better soil and cultivation than the flat varieties. See page 13.

\section{Purple Top Turnips}

The standard for this part of the country for late planting. One of the best table and stock sorts on the market, fine grained and of mild flavor. Of good size, flat shape, pure white below with purplish red top. Good cropper and excellent keeper. See page 21.

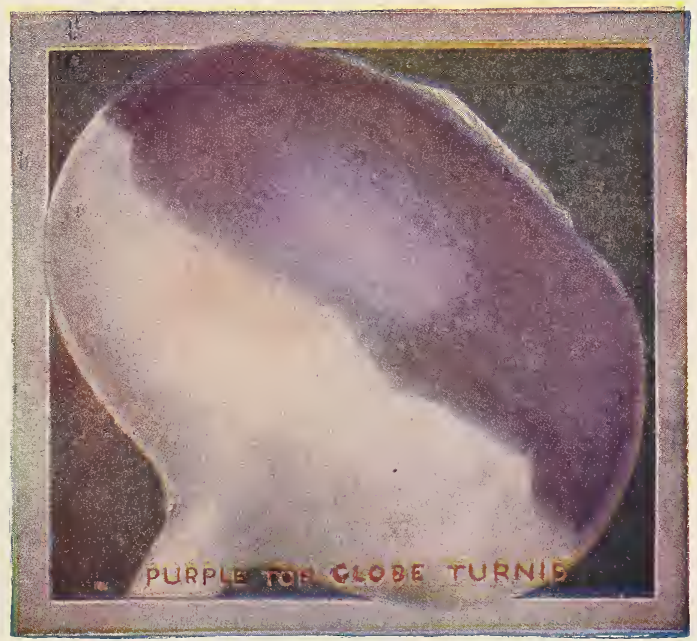




\section{Alfalfa}

No crop is so valuable for permanent meadow as Alfalfa. In ordinary seasons two crops of hay are cut in the North generally, while some seasons produce three and even four cuttings. It stands the dry, hot weather of July and August, and continues green and growing when other grasses are dormant. Actual tests of seed

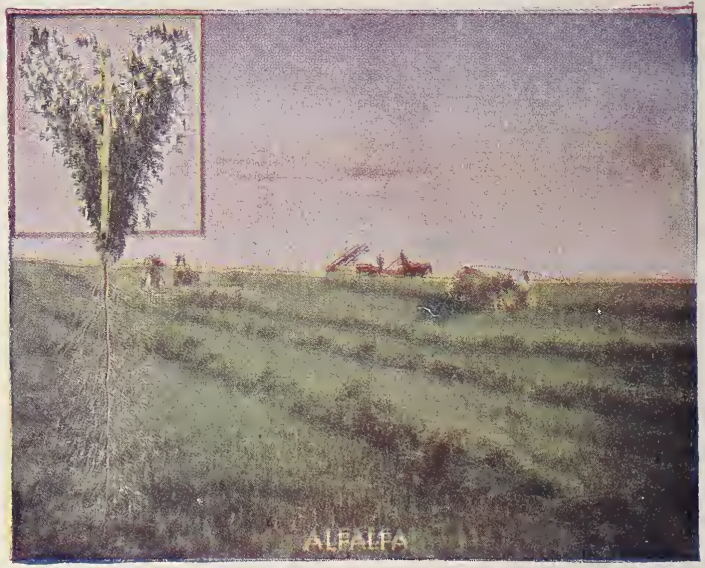

from all over the United States show that the stocks produced in the semiarid districts of the Northwest give the best results and are hardier than stocks grown farther south. See page 40.

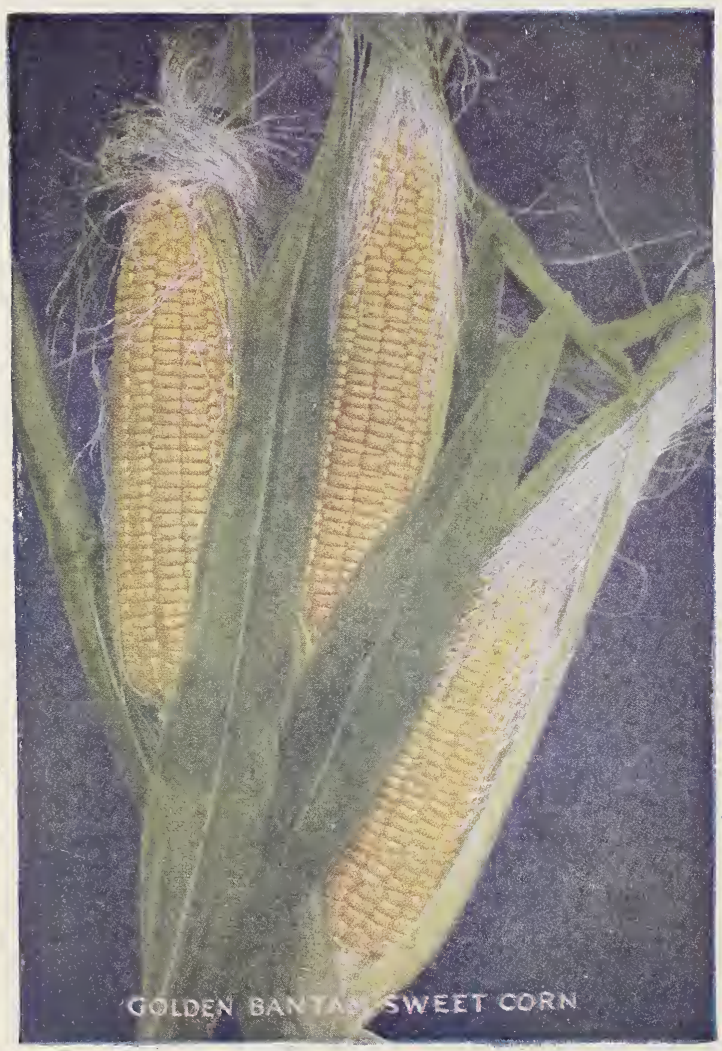

\section{Our Improved Golden Bantam Sweet Corn}

This is one of the most delicious of all; it is generally believed to be the richest in flavor. Is extremely early, of hardy, vigorous growth, so that it can be planted quite early. Some say it is as sweet as honey. See page eight. Des Moines, Iowa 